UNIVERSIDADE DE SÃO PAULO

INSTITUTO DE QUÍMICA

\author{
PRODUÇÃo E CARACTERIZAÇÃo DE \\ "FIBROBLAST GROWTH FACTOR (FGF)" \\ RECOMBINANTE
}

CATARINA AKIKO MIYAMOTO

Dissertação de Mestrado submetida ao Departamento de Bioquímica do Instituto de Química da Universidade de São Paulo.

Orientador: Dr. Angelo G. Gambarini

SÃO PAULO

1992 


\title{
PRODUÇÃo E CARACTERIZAÇÃo DE "FIBROBLAST GROWTH FACTOR (FGF)" RECOMBINANTE
}

\begin{abstract}
Dissertação de Mestrado submetida ao Instituto de Quími ca da Universidade de São Paulo como parte dos requisitos necessários à obtenção do grau de Mestre em Bioquímica.
\end{abstract}

Aprovada por:

Prof. Dr. Angelo Geraldo Gambarini

(Orientador e Presidente)

Profa. Dra. Suely Lopes Gomes, IQ-USP

Prof. Dr. Osvaldo Marinotti, ICB-USP

SÃo PAULO, SP

12 DE MARÇO DE 1992 


\section{AGRADEC IMENTOS}

Ao Angelo Gambarini pela orientaço e incentivo na realizacao deste trabaliho;

Ao Dr. Hugo Armelin por ter me aberto as portas deste laboratório e discussôes sempre proveitosas:

A Eico Kimura pela colaborafáo em momentos importantes durante a realizaço deste trabaliho;

Ao Ronaldo Bento Quaggio pelas dicas e discussoes sobre a arte da subclonagem e auxilio no manuseio dos programas de computafao;

A Katia Maria da Rocha, amiga essencial, prestativa e presente em todos os momentos dificeis, pelo auxilio incondicional e discussbes agradáveis;

A Claudia Frigeri, amiga leal, pela presenca marcante, convivencia agradavel e apoio técnico;

A Cecflia Bonilha, pela amizade e companheirismo;

A D. Joana Criscuolo, pelo cuidado na preparacão do material do laboratório e carinho;

A Sheila Jensen, Marcella Faria e Ana Paula Lepique, pela amizade;

A Mineko Tominaga, pelos bons conselhos e ombro amigo;

Ao Paulo Lee Ho, pela amizade e discussoes valiosas;

Ao Chuck Farat, pela revisao do "summary" e auxilio no manuseio do programa macplasmap;

Ao Flavio Henrique "Mineirinho", pelo auxilio no sequenciamento do DNA e amizade;

Ao Fernando Reinach, pelo vetor e cepas bacterianas;

A Martha Sonobe e Mari Armelin, pelo vetor pUC19;

Ao Dorry e Wiltan, pelos oligonucleotideos;

A Lúcia, Cassandra, Sandro, Zizi, Eduardo, Ricardo, Claudio, Eugenia e Emerson, pelas boas festinhas;

A Kumie e Ana Claudia, pelo incentivo e bate-papos formais e informais; 
Ao Marcelo, pela revisao final do texto e seriedade por vezes burlada;

A Franca, pelo auxilio na anhlise de aminóacidos;

Ao Pio Colepicolo, Denise e Horacio, pela gentileza de emprestar o computador Macintosh para a realizaço dos graficos dos plasmideos;

A Moema, pela revisao das referencias bibliograficas;

A Dra. J. A. Abraham (California Biotechnology, Inc., CA, USA), por ter cedido os plasmideos pJC3-5 e pJJ11-1;

Ao Dr. F. W. Studier (Brookhaven National Lab., NY, USA), por ter permitido o uso do plasmideo pET3-d;

Ao Dr. W. Mckeehan (W. Alton Jones Cell Science Center, NY, USA), por ter cedido o antisoro anti-aFGF $Y-34-A$;

Ao Ricardo "Zé", Patricia, Jonny, Hioka, Mercedes, Palmira, Mauricinho, Xuds, Abrahao e Pepe, pela bagunca do dia-a-dia;

Aos laboratórios do IQ pelos emprestimos dos aparelhos dos quais necessitei;

Ao CNPQ, FAPESP e FINEP, pelos auxilios concedidos;

Ao Fabio e Ana Paula, pela amizade e carinho sempre constantes. 
RESUMO

Este trabaliho descreve a producăo dos fGFs basico bovino (bb) e acido humano (ha) em E. coli utilizando o vetor pET. Para expressar o hafGF utilizamos o cDNA nativo com pequenas modificaçaes, obtendo cerca de $40 \mathrm{mg} d a$ proteina por litro de cultura induzida. No caso do bbFGF, cerca de 60 pares de bases da extremidade $5^{\circ}$ do CDNA nativo foram substituidos por oligonucleotideos sintéticas contendo codons frequentemente usados em genes bacterianos altamente expressos e apresentando menor conteúdo de $C+G$ do que a sequencia nativa. Com este cDNA modificado, obteve-se cerca de $10 \mathrm{mg} 1^{-1}$ de bbFGF. Os FGFs intracelulares solúveis foram purificados a partir do extrato bacteriano por cromatografia de afinidade em Heparina-Sepharose atingindo um grau de pureza da ordem de $95 \%$. O hafGF sozinho é ativo sobre fibroblastos $3 T 3$ em cultura na concentraço de ng mi-1; na presenca de heparina, a atividade desloca-se para a faixa de $p g m^{-1}$. O bbFGF e ativo na concentracáo de pg $m^{-1}$ e sua atividade năo é significantemente potenciada pela heparina. O sequenciamento da extremidade N-terminal e a análise de aminokcidos mostraram somente uma forma de hafGF recombinante correspondente a proteina autentica de 154 aminoacidos. Foram encontradas duas formas de bbFGF recombinante, uma correspondente a proteina autentica de 154 residuas e outra contendo 153 , onde os dois primeiros foram removidos. 
SUMMARY

Here we describe the use of the PET expression system to produce the 154 amino acid bovine basic (bb) and human acidic (ha) FGFs. To express haFGF we have used the native cDNA sequence with minor modifications, obtaining about $40 \mathrm{mg}$ of growth factor per liter of bacterial culture. In the case of bbFGF, about 60 base pairs from the 5'-end of the native CDNA were replaced with synthetic oligonucleatides containing codons frequently used in highly expressed bacterial genes and having a lower G+C content than the native sequence. By using this modified CDNA about $10 \mathrm{mg}$ $1^{-1}$ of bbFGF was obtained. The intracellular, soluble fGFs were partially purified from bacterial extracts by heparin-affinity chromatography and shown to be more than $95 \%$ pure. The hafGF alone is active upon $3 T 3$ fibroblasts in culture at the level of $n g \mathrm{ml}^{-1}$ or in the range of $\mathrm{pg} \mathrm{ml}^{-1}$ when heparin is added to the incubation medium. The bbFGF is active in the range of $\mathrm{pg} \mathrm{m}^{-1}$ and its activity is not significantly potentiated by heparin. Only one form of recombinant hafGF corresponding to the authentic protein of 154 amino acids was found by $N$-terminal protein sequencing and amino acid analysis. Two forms of recombinant bbFGF were found, one corresponding to the authentic protein of 154 amino acids (about $75 \%$ ) and another containing 153 amino acids where the first two residues were removed (about $25 \%$ ). 


\section{ABREVIATURAS}

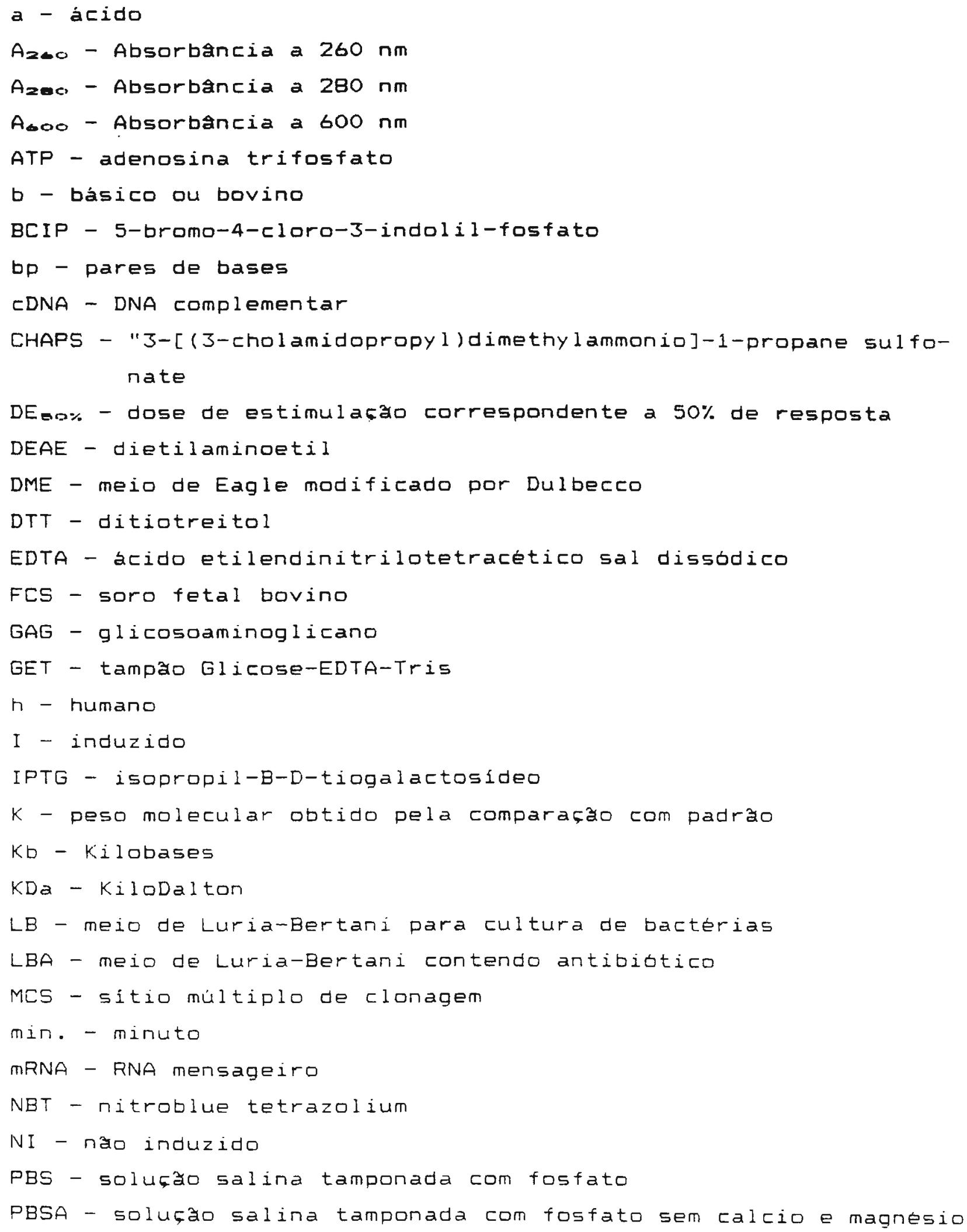




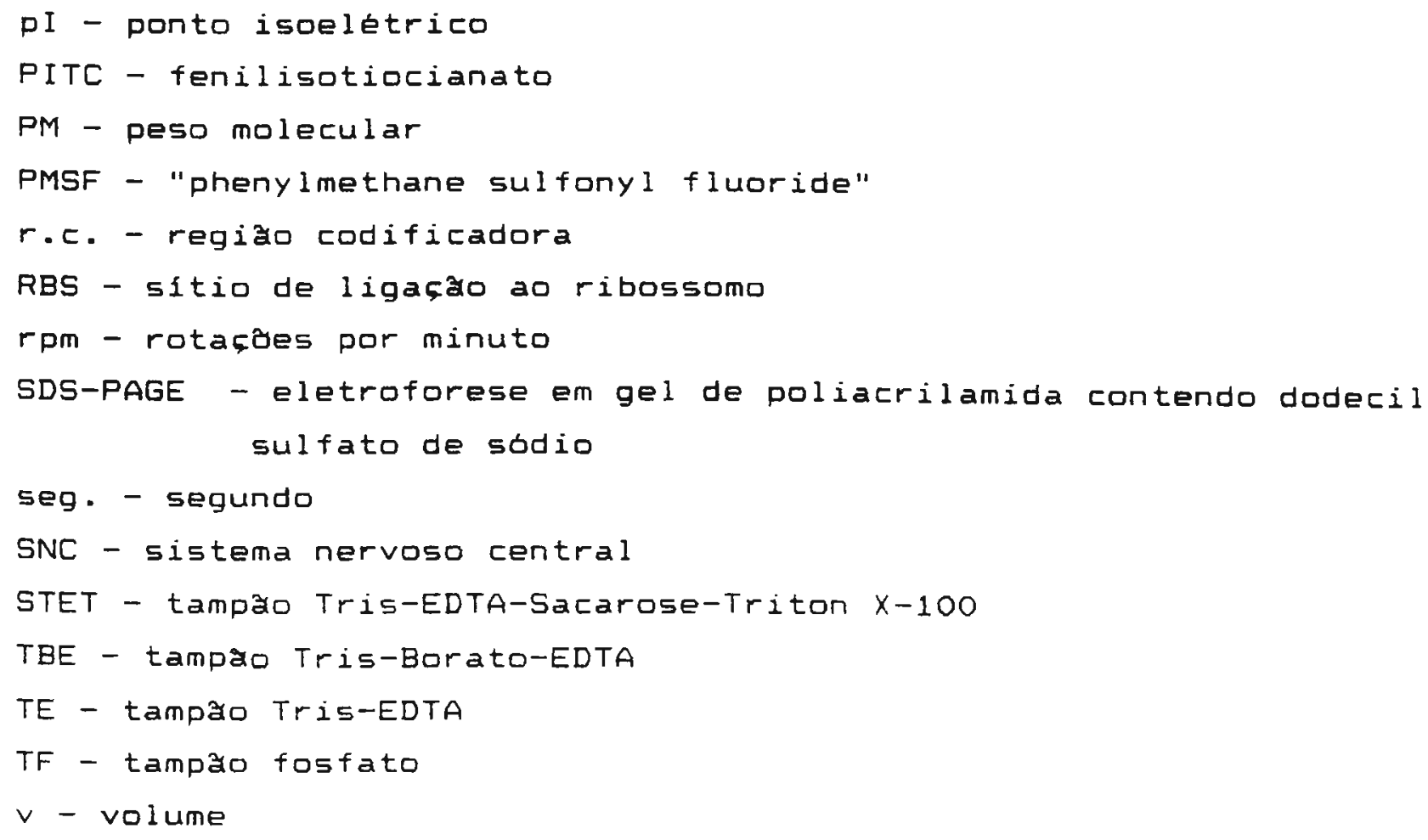




\section{IND ICE}

1. INTRDDULARD............................ 01

1.1. Historico......................... 02

1.2. Atividades dos fGFs..........................

1.3. Estrutura primaria dos FGFs acido e básico........ 04

1.3.1. Estrutura primaria do bFGF............ 05

1.3.2. Estrutura primária do aFGF............ 07

1.3.3. Analise das estruturas dos FGFs.......... 09

1.4. Organizacăo dos genes.................... 10

1.5. Expressão dos FGFs recombinantes.............. 11

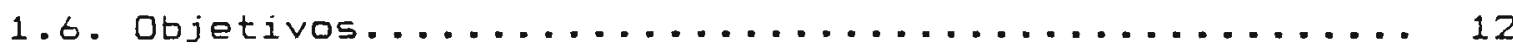

2. Materiais e metqdos........................ 13

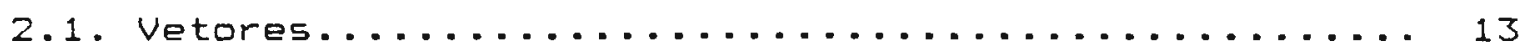

2.2. Hospedeiros........................... 16

2.3. Transformacăo de E. coli com DNA plasmidial...... 16

2.4. Extracão de DNA plasmidial................ 17

2.5. Purificaça do DNA plasmidial em CsCl........... 18

2.6. Mini-preparacdes de plasmideos.............. 19

2.7. Eletroforese em gel de agarose............... 19

2.8. Recuperacão de fragmentos de DNA atraves de eletroforese sobre membrana de DEAE-celulose.......... 20

2.9. Reacão de ligase....................... 21

2.10. Dessalinizacão de oligonucleotideos sinteticos: cromatografia de gel-filtracăo em coluna de Sepha-

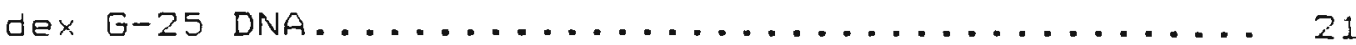

2.11. Hibridizacăo fosforilacao dos oligonucleotideos. 23

2.12. Estrategias utilizadas para subclonagens....... 23

2.12.1. Subclonagem de hafGF em pKK233-2....... 23

2.12.2. Subclonagem de haFGF em PET-3d......... 24

2.12.3. Subclonagem de bbFGF em pET-3d......... 25

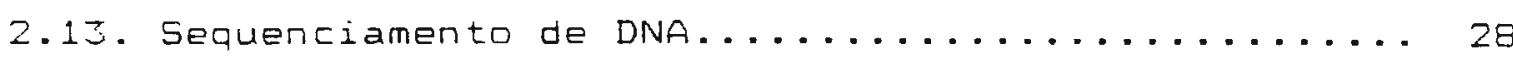

2.14. Eletroforese de sequenciamento de DNA......... 28

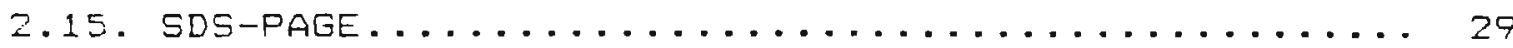

2.16. Western-Blotting..................... 29 
2.17. Sistema de expressao usando vetor pKK......... 30

2.18. Sistema de expressão usando vetor PET.......... 30

2.19. Inducăo da expressão de proteinas em E. coli..... 31 2.19.1. Induço da expressao de hafGF utilizando

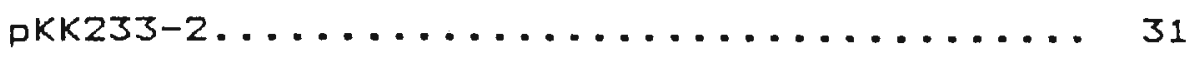

2.19.2. Induça da expressao de hafGF e bbFGF Ltilizando pET-3d................. 32

2.20. Preparafzo das amostras de proteinas.......... 32

2.20.1. Mini-preparacoes de proteinas.......... 32

2.20 .2 . Preparacoles das amostras de proteinas em

larga escala utilizando vetor pET-3d...... 33

2.21. Cromatografia de afinidade em coluna de Heparina-

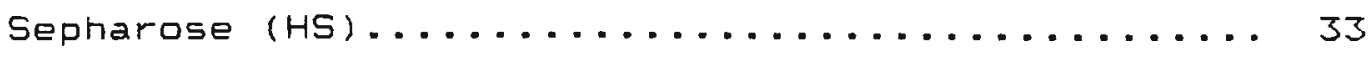

2.22. Ensaios de atividade biológica............ 34

2.23. Dosagem de proteina................. 35

3. RESUltAdOS............................... 36

3.1. Transformaca de E. coli................ 36

3.2. Extraça e purificacáo de DNA plasmidial........ 37

3.3. Obtencáo dos plasmideos de expressao de FGF....... 40

3.3.1. Obtenço de pJKA-1................ 40

3.3.2. abtença de pJEA-1................ 44

3.3.3. obtença de pJeB-1............... 45

3.4. Expressao das proteinas................ 48

3.4.1. Expressáo em pequena escala de hafgf com pkK233-2.................... 48

3.4.2. Expressao de hafGF e bbFGF com pET-3d..... 50

3.4.2.1. Expressao em pequena escala....... 50

3.4.2.2. Expressao em larga escala........ 53

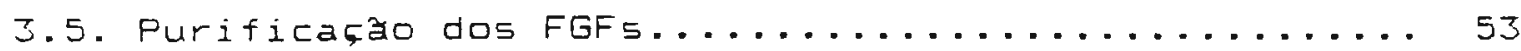

3.5.1. Purificaço de hafGF e ensaio de atividade mitogenica das fracóes cromatográficas..... 53

3.5.1.1. Eluiço atraves de gradiente de $\mathrm{NaCl}$ por etapas................... 53

3.5.1.2. Eluiçao atraves de gradiente linear

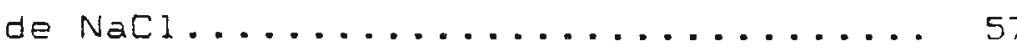


3.5.2. Purificafao de bbFGF e ensaio de atividade mitogenica das fraçôs cromatograficas..... 62

3.6. Analises da composigăo e sequenciamento de aminoácidos dos fGFs produzidas.................... 65

4. Discussa .............................. 67

5. REFERENCIAS BIBLIOGRAFICAS.................. 71 
INDICE DE FIGURAS E TABELAS

Figura 1: Sequencias de nucleotideos e de aminokcidos da regiao codificadora do cDNA do bFGF bovino

Figura 2: Sequencias de nucleotideos e de aminoácidos da regiao codificadora do EDNA de aFGF humano

Figura 3: Esquema dos fragmentos de DNA de haFGF $e$ de bbFGF inseridas em pJC3-5 e pJJ11-1, respectivamente. (a) PJC3-5 - haFGF+pBR329 E (b) pJJ11-1 - bbFGF+pBR322 14

Figura 4: Plasmideos de expressâo utilizados. (a) pKK233-2; (b) PET3-d

Figura 5: (a) Extremidade 5' da regiao codificadora nativa de bbFGF que foi substituida pelos 4 oligonucleotideos sinteticos; (b) Desenho dos 4 oligonucleotideos que foram sintetizados para substituir a extremidade 5' da regiao codificadora nativa de bbFGF

Figura 6: Eletroforese de pET3-d e do fragmento de haFGF apos digestao com NcoI-HindI I 24

Figura 7: Principais sitios de restrifăo do cDNA nativo de DLFGF

Figura 8: Esquema de subclonagem de bbFGF em pET3-d

Figura 9: Eletroforese das preparaçäes de vários DNAs plasmidiais (forma "supercoil")

Figura 10: Eletroforese das preparacoes de DNAs plasmidiais após digeståo com HindII

Figura 11: Eletroforese dos plasmideos dos ciones isolados da placa proveniente da suspensao 2 (Tabela IV), digeridos com Hind I I

Figura 12: Eletroforese dos 6 clones digeridos com HindII E EcoRI que apresentaram aumento no "PM" apos digestão com Hind I I I

Figura 13: Plasmideos com bbFGFmodif. 
Figura 14: Western-blotting das fracoles proteicas das amostras induzidas (I) e nao induzidas (NI) dos clones $2,4,5,7,9$ e 10 de hafGF utilizando sistema pKK 49

Figura 15: SDS-PAGE para verificacao do nivel de expressao de haFGF utilizando sistema pET

Figura 16: SDS-PAGE de 1 clone que nào expressou e de 3 que expressaram bbFGF utilizando sistema $p E T$

Figura 17: Eluifao de hafGF atraves de gradiente por etapas de $\mathrm{NaCl}$

Figura 18: Purificacao de hafGF utilizando-se gradiente de NaCl por etapas

Figura 19: Eluigao de haFGF atraves de gradiente linear de $\mathrm{NaCl}$

Figura 20: Purificaça de haFGF utilizando-se gradiente linear de $\mathrm{NaCl}$

Figura 21: Curva de dose-resposta do hafGF e efeito de duas concentraçoses da heparina ma atividade do hafGF 61

Figura 22: Eluicáo de bbfGF atraves de gradiente linear de $\mathrm{NaCl}$

Figura 23: Purificacao de bbFGF atraves de gradiente linear de $\mathrm{NaCl}$

Tabela I: Selecáo de bacterias transformantes em placas LBA 36

Tabela II: Concentraça de DNA plasmidial estimada após extraça

Tabela III: Concentracao de DNA plasmidial (forma "supercoil" após purificacao em gradiente de cloreto de césio 38

Tabela IV: Clones transformados pela reaçao de ligacăo pKK2JJ-2 + haFGF

Tabela $V:$ Resultados de transformacáo plasmideos gerados da ligacăo de haFGF (NCOI-Hind I I )

de E. COli HMS 174 com os DETJ-d (NEOI-HindIII) + 44 


\section{INTRODUCAO}

Fatores de crescimento polipeptidicos sao moduladores da proliferaçao e da diferenciacao celular in vitro e in vivo. Estas respostas sao desencadeadas, em parte, pela interafao destes fatores com receptores de alta afinidade localizados na superficie celular. A sequencia de reacbes iniciada pela ocupacao dos receptores pelos fatores de crescimento nao está ainda estabelecida completamente. A regulaço anormal de uma ou mais destas reacoes é um dos fatores que explicaria o mecanismo dos oncogenes celulares e os fenotipos resultantes associados com transformaça celular (Burgess \& Maciag, 1989).

Um desses fatores e o "Fibroblast Growth Factor" (FGF), que constitue uma familia composta de sete polipeptideos com propriedades estruturais, bioquimicas e biologicas similares (Burgess \& Maciag, 1989; Thompson \& cols., 1991; Baird \& Klagsbrun, 1991 ).

Com a disponibilidade de proteinas purificadas, sondas de cDNAs e anticorpos, o conhecimento das propriedades estruturais e biologicas dos FGFs expandiu-se grandemente. Atualmente, sabe-se que: 1.) sao fatores multifuncionais que tem atividades mitogenica, quimiotatica, neurotrofica e angiogenica in vitro e in vivo; 2.) săo codificados por uma familia de genes, contendo pelo menos sete membras; 3.) interagem com múltiplas receptares de alta e de baixa afinidades; 4.) associam-se com heparina e com - proteoglicano heparam sulfato existente nas superficies celulares e na matriz extracelular; 5.) tem um importante papel nos processos do desenvolvimento (Baird \& Klagsbrun, 1991 ). Devido a estas propriedades os fGFs podem ser explorados clinicamente. 


\subsection{Historico}

A motivaça para a identificacăo dos FGFs originou-se com a proposigzo de que fatores solúveis eram responsaveis pela regulaça de uma variedade de processos fisiologicos, incluindo desenvolvimento, regeneraça e cicatrizaczo.

Em 1939, extratos de cerebro foram citados como fontes ricas de fatores que promoviam a proliferacao de fibroblastos in vitro (Burgess \& Maciag, 1989). No final da decada de 60 e inflio da de 70 , verificou-se que preparaçes dos hormonios estimulante de tiredide (derivado da hipofise) e luteinizante continham um potente polipeptideo mitogenico para celulas de camundongo 3 T3 e condrócitos. Armelin (1973) descreveu os efeitos de extratos hipofisarios sobre o crescimento de celulas $3 T 3$ propondo a existencia de um regulador da proliferacao destas celulas. Gospodarowicz (1975) purificou e caracterizou parcialmente 0 polipeptideo a partir de extratos acidos de hipofises bovinas, como uma proteina de PI 9,6 e PM 13,5 KDa. A composicao de aminokcidos e o residuo N-terminal (lisina) foram determinados. Este polipeptideo foi denominado "fibroblast growth factor". Subsequentemente, mostrou-se que ele era mitogenico para uma grande variedade de celulas derivadas do mesoderma e neuroectoderma. Gospodarowicz \& cols. (1975) identificaram um FGF acido ( $I$ I 5 - 6) pela sua capacidade em causar a proliferacáo e a diferenciacáo retardada de mioblastos. Thomas \& cols. (1980), independentemente, detectaram a presenca de um polipeptideo en extratos de cerebro bovino que foi denominado FGF acido. Mostrou-se que os FGFs acido (a) e basico (b) eram potentes mitogenicos para celulas endoteliais e que se ligavam fortemente a heparina (Gospodarowicz \& cols., 1987a; Burgess \& Maciag, 1989).

Antes da elucidaça da estrutura primaria dos fGFs, muitos laboratorios isolaram-nos a partir de varios tecidos, orgaose culturas de celulas e identificaram-nos sob diferentes nomes (acima de 30 ), dependendo da origem ou celulas alvo. Atualmente, sabe-se que a maioria destes fatores de crescimento correspondem 
ao bFGF ou ao aFGF (Gospodarowicz \& cols., 1987a; Burgess \& Maciag, 1989; Baird \& Klagsbrun, 1991).

A caracterizaça estrutural demonstrou que o bFGF $a$ aFGF sao relacionadose servem como protótipos de uma familia de fatores de crescimento que inclui, pelo menos, cinco outros membros: a proteina codificada pelo oncogene int-2; os produtos dos oncogenes humanos FGF-s e hst/K-fqf; o produto de um gene isolado por homologia a hst/K-fqf (FGF-6/Hst-2); e o "keratinocyte growth factor" (KGF) (Burgess \& Maciag, 1989; Thompson \& cols., 1991; Baird \& Klagsbrun, 1991).

\subsection{Atividades dos FGFs}

Os FGFs acido e básico săo multifuncionais, uma vez que eles podem tanto estimular a proliferacao como induzir ou retardar a diferenciacao celular. O mecanismo molecular da acao desses fGFs náo e conhecido até o presente. Entretanto, novas e variadas funcoes tem sido descritas para os dois fatores de crescimento (Gospodarowicz \& cols., 1987a: Burgess \& Maciag, 1989).

Os dois fGFs sao potentes proteinas mitogenicas capazes de induzir a divisao celular em uma grande variedade de tipos celulares (Gospodarowicz \& cols., 1987a; Burgess \& Maciag, 1989). Eles tem atividade angiogenica in vivo e in vitro. Em celulas endoteliais em cultura, os dois fGFs induzem a complexa resposta angiogenica (Squires \& cols., 1989; Watanabe \& cols., 1990), que abrange um aumento na proliferacao celular, motilidade e producăo de proteases (Moscatelii \& cols., 1986; Presta \& cols., 1986; Knoerzer \& cols., 1989). Um efeito pronunciado dos afGF e bFGF, - de manter neuronios viaveis e diferenciados em cultura, mostra que eles sao fatores neurotróficos (Gospodarowicz \& cols., 1987a). Células PCi2 derivadas de feocromocitoma, usadas como modelo de diferenciacao neuronal, quando incubadas com estes fatores formam neuritos (Togari \& cols., 1983).

Em adiça ao seu papel como ativador mitogenico ou fator de crescimento, mostrou-se que o bFGF tem algumas atividades nao 
mitogenicas. Baird \& cols. (1985) mostraram seu papel regulatório na secreço de tirotropina e prolactina. Sporn \& Roberts (1988) relataram que o FGF tem efeito inibitorio sobre celulas de sarcoma de Ewing e outras celulas tumorais. PlataSalaman (1988) relatou que a injeço intraventricular do bFGF no cerebro de ratos suprime a absorcáo de alimentos. Okumura \& cols. (1991) demonstraram que, injetando-se bFGF intracisternalmente, este inibe a secreço gastrica de modo dose-dependente. Estes dois dados sugerem que $\square$ bFGF pode ter um papel neuromodulador em várias funçBes do SNC.

\subsection{Estrutura primária dos FGFs acido e basico}

Os FGFs acido e basico 5 zo moleculas relacionadas e com propriedades similares. Eles diferem entretanto em algumas de suas propriedades fisicas e quimicas e na distribuicao tecidual. Enquanto o aFGF é encontrado principalmente no cerebro e retina, - bFGF tem uma distribuicao mais ampla, sendo encontrado, por exemplo, em hipofise, cérebro, adrenal, ovario, rim, macrofago, retina, prostata, figado e condrossarcoma (Gospodarowicz \& cols., 1987a; Burgess \& Maciag, 1989).

\subsubsection{Estrutura primaria do DFGF}

A sequencia de aminoácidos do bFGF bovino, purificado como um polipeptideo de cadeia unica, composta de 146 aminoácidos $\left(\simeq_{15}\right.$ - $16 \mathrm{KDa}$, de $\mathrm{PI} 9-10$, foi primeiramente descrita por Esch \& cols. (1985).

Com o isolamento de clones de cDNAs codificando para os bFGFs bovino e humano (Abraham \& cols., 1986a, 1986b), pode-se deduzir que muito provavelmente o produto primario de traducao e uma proteina de 155 aminoacidos (Figura 1 ), uma vez que encontrou-se um ATG na porcao $5^{\prime}$ do gene que estava em fase com os codons subsequentes no bFGF. Experimentos posteriores 
demonstraram que esta proteina, cuja extremidade N-terminal estava bloqueada (acetilada), poderia ser obtida a partir de hipofises na presenca de inibidores de proteases durante o isolamento e purificacăo da protelna (Ueno \& cols., 1986). Estas observacoes indicam que a forma de bFGF de 146 aminoacidos $e$ outras formas menores (Gospodarowicz \& cols., 1985; Gospodarowicz \& cols., 1986; Klagsbrun \& cols., 1997; Ho \& cols., 1988) sao geradas durante a purificafáo atraves de proteólise da porfáo Nterminal (Klagsbrun \& cols., 1987; Ho \& cols., 1990), enquanto a forma de 155 residuos representaria a verdadeira forma nativa da proteina (Thompson \& cols., 1991). Dutros autores (Florkiewicz \& Sommer, 1989; Prats \& cols., 1989) apresentaram evidencias da existencia de formas maiores de bFGF humano originadas atraves da traduczo a partir de codons CTG (Ieucina) nas posicbes -41 , -46 e -55 em relacao do ATG inicialmente proposto. Estes experimentos indicaram ainda que o inicio da traducao poderia ocorrer tambem no ATG proposto inicialmente, originando portanto, quatro produtos possiveis de traducăo primaria para a proteina humana. contendo, respectivamente, $155,196,201$ ou 210 residuos de aminoácidos. 


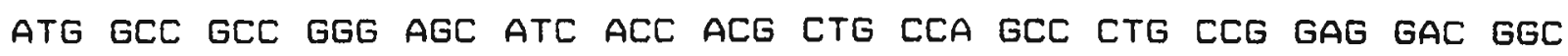

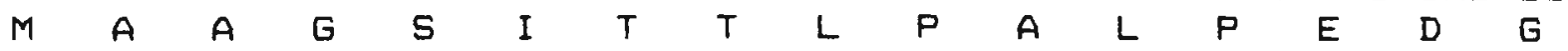

110

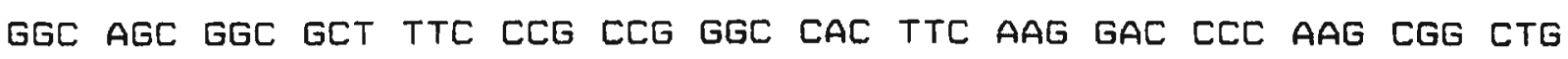
$\begin{array}{llllllllllllllll}G & S & G & A & F & P & P & G & H & F & K & D & P & K & R & L \\ & & 20 & & & & & & & & & & 30 & & \end{array}$

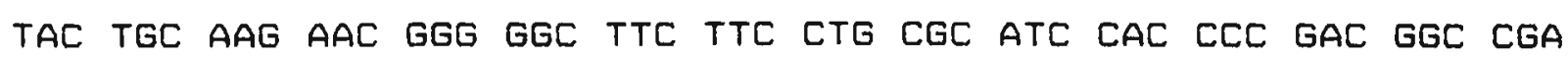
$\begin{array}{llllllllllllllll} & C & K & N & G & G & F & F & L & R & I & H & P & D & G & R\end{array}$ 40

GTG GAC GGg GTC CGC GAG aAg aGC GAC CCA CAC ATC AAA CTA CAA CTT $\begin{array}{llllllllllllllll}V & D & G & V & R & E & K & S & D & P & H & I & K & L & G & L\end{array}$ CAA GCA GAA GAG AGA GGG GTT GTG TCT ATC AAA GGA GTG TGT GCA AAC $\begin{array}{llllllllllllllll}Q & A & E & E & R & G & V & V & S & I & K & G & V & C & A & N \\ & & & & & & & & & & & \end{array}$ CGT TAC CTT GCT ATG AAA GAA GAT GGA AGA TTA CTA GCT TCT AAA TGT

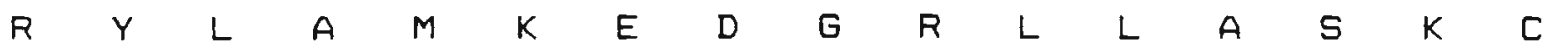

GTT aCA GAC GAG TGT TTC TTT TTT GAA CGA TTG GAG TCT AAT AAC TAC $\begin{array}{llllllllllllllll} & T & D & E_{100} & C & F & F & F & E & R & L & E & S & N & N & Y\end{array}$

aAt act tac cGg tCA agg aAa tac tCC agt tGg tat gtg gCA ctg aAa $\begin{array}{llllllllllllllll}N & T & Y & R & S & R & K & Y_{120} & S & S & W & Y & V & A & L & K\end{array}$

CGA ACT GGg CAG TAT AAA CTT GGA CCC AAA ACA GGA CCT GGG CAG AAA

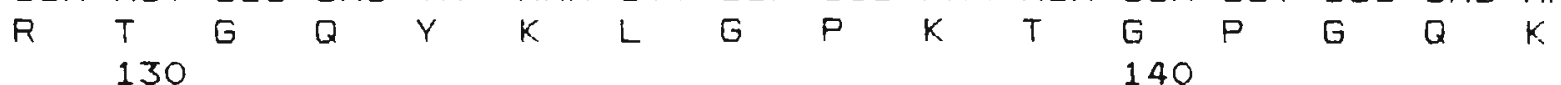

GCT ATA CTT TTT CTT CCA ATG TCT GCT AAG AGC TGA $A \quad I \quad L \quad F \quad L \quad \begin{array}{lllllll}P & M & S & A & K & S & *\end{array}$

Fiqura 1. Sequencias de nucleotideos e de aminoacidos da regiăo codificadora do cDNA do bFGF bovino (Abranam \& cols., 1986a). 


\subsubsection{Estrutura primaria do aFGF}

A sequencia de aminoacidos do afGF bovino de 140 residuos [15-154] foi primeiramente descrita por Gimenez-Gallego \& cols. (1985). $\square$ aFGF foi purificado como um polipeptideo de cadeia única, de $\mathrm{pI} 5-6$ e cerca de $16 \mathrm{KDa}$. Formas truncadas na regizo N-terminal tambem foram descritas (Burgess \& cols., 1986; Mckeehan \& Crabb, 1987). As sequencias completas dos aFGF humano [1-155] (Crabb \& cols., 1986 e Jaye \& cols., 1986) e bovino (Burgess \& cols., 1986) foram elucidadas. A analise da sequencia dos nucleotideos do CDNA de afGF humano demonstra que a regiao codificadora corresponde a uma proteina de 155 residuos de aminoácidos (Figura 2), năo havendo outros codons de iniciaço alternativos na extremidade $5^{\prime}$. Alem disso, há um codon de terminacao (TGA) na posiço -6 em relacao ao ATG inicial proposto (Jaye \& cols., 1986). 
ATG GCT GAA GGG GAA ATC ACC ACC TTC ACA GCC CTG ACC GAG AAG TTT $\begin{array}{llllllllllllllll}M & A & E & G & E & I & T & T & F & T & A & L & T & E & K & F\end{array}$ 110

AAT CTG CCT CCA GGG AAT TAC AAG AAG CCC AAA CTC CTC TAC TGT AGC $\begin{array}{llllllllllllllll}N & L & P & P & G & N & Y & K & K & P & K & L & L & Y & C & S\end{array}$ 2030

AAC GGG GGC CAC TTC CTG AGg ATC CTT CCG GAT GGC ACA GTG GAT GGG $\begin{array}{llllllllllllllll}N & G & G & H & F & L & R & I & L & P & D & G & T & V & D & G\end{array}$ acA agg gac agg agC gac cag cac att cag ctg cag ctC agt gCG gaA $\begin{array}{llllllllllllllll}T & R & D & R & S & D & Q & H & I & Q & L & { }_{60} & L & S & A & E\end{array}$ agC gTg gGg gag gtg tat ata aAg agt acC gag act gGC CAG tac tTG $\begin{array}{llllllllllllllll}S & V & G & E & V & Y & I & K & S & T & E & T & G & Q & Y & L \\ 70 & & & & & & & & & & 80\end{array}$

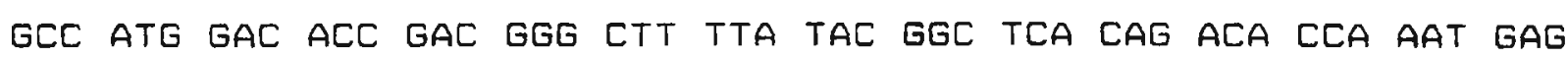

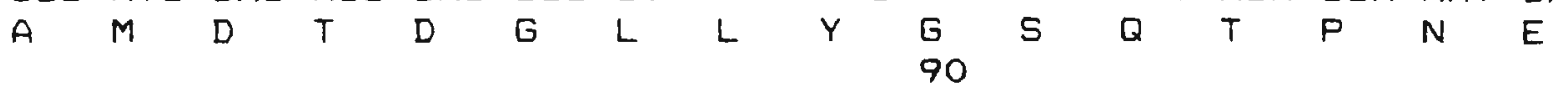
gaA tgt tTG tTC ctg gaA agg ctg gag gag aAC cat tac aAc acc tat

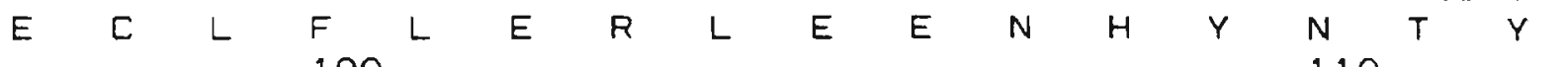
$100 \quad 110$

ata tcl aAg aAg cat gCa gag aAg aAt tgg tTt gtt gGC ctc aAg aAg $\begin{array}{llllllllllllllll}I & S & K & K & H & A & E & K & N & W & F & V & G & L & K & K\end{array}$ 120

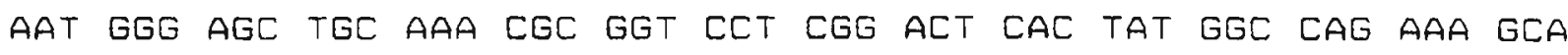
$\begin{array}{lllllllllllllllll}N & G & S & C & K & R & G & P & R & T & H & Y & G & Q & K & A \\ 130 & & & & & & & & & & 140 & & & & \end{array}$

ATC TTG TTT CTC CCE CTG CCA GTC TLT TCT GAT TAA

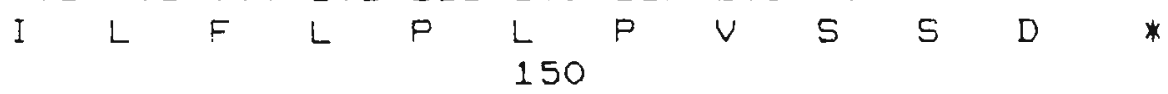

Fiqura 2. Sequencias de nucleatideos e de aminoácidos da regiăo codificadora do cDNA de aFGF humano (Jaye \& cols., 1986). 


\subsubsection{Analise das estruturas dos FGFs}

A analise dos genes clonados, assim como das proteinas extraidas de tecidos, revela uma homologia de sequencia de aminokcidos da ordem de 50\% entre estas duas classes de proteinas ( $a F G F$ bFGF).

As duas proteinas tem grande afinidade por heparina. Devido a esta caracteristica, o aFGF 0 o bFGF foram tambem chamados, respectivamente, de "heparin-binding growth factors" 1 e 2 (HBGF1 e HBGF-2) (Burgess \& Maciag, 1989). Existem dois dominios potenciais de ligacáo a heparina, un localizado na regiao $N-$ terminal e outro na regizo C-terminal: para o bFGF, residuos 1822 e 107-110 e para o aFGF, residuos 9-12 e $100-102$ (Gospodarowicz \& cols., 1987a, 1987b). Evidencias quimicas e biológicas mais recentes sugerem que o domfnio de ligafao a heparina do bFGF pode ser uma estrutura tridimensional que envolve regioes nå contiguas da molecula (Baird \& Klagsbrun, 1991). Sabe-se que a heparina pode induzir a exposiço de epitopos imunologicamente sensiveis no afGF a protege os dois fatores de inativafão por calor e por ácido, e de ataques proteoliticos (Burgess \& Maciag, 1989). A heparina é particularmente importante na modulaço da atividade do afGF, potenciando sua atividade mitogenica, aparentemente prolongando a vida média do fator no meio de cultura. Näo há efeito sinergistico comparável da heparina sobre o bFGF, que entretanto age como uma "molecula transportadora" deste fator, aumentando grandemente seu raio de aço (Burgess \& Maciag, 1989; Baird \& Klagstrun, 1991 ).

Us produtos de traducåo primaria dos dois fatores de erescimento năo săo glicosilados nem tem peptideo sinal classico para secrecă, embora existam receptores de superficie celular para estas proteinas (Burgess \& Maciag, 1989; Thompson \& 5015. , 1991). Por outro lado, 0 aFGF tem sequencia de translocafáa nutlear (NYKKPKL - Figura 2) (Imamura \& cols., 1990).

0 DFGF manteve-se bem conservado atraves da evolucao. Por exemplo, os bFGFs bovino (b) e humano (h) diferem em somente 2 
aminoacidos. Para transformar o bbFGF em hbFGF, basta mutar o residuo 121 de serina para treonina e o residuo 137 de prolina para serina (Abraham \& cols., 1986a). O mesmo nao ocorreu com o aFGF; a forma bovina difere da humana em 11 residuos (Gospodarowicz \& cols., 1987b).

\subsection{Orqanização dos qenes}

- alto grau de homologia entre afGF e bFGF sugere que eles sejam derivados de um gene ancestral comum (Gospodarowicz \& cols., 1987b). Os genes dos FGFs foram clonados e as sequencias dos DNAs complementares (CDNAS) foram sintetizados: afGF humano por Jaye \& cols. (1986), bFGF humano por Abraham \& cols. (1986b) e Kurokawa \& cols. (1987), a bFGF bovino por Abraham \& cols. (1986a).

As sequencias de aminoacidos preditas atraves dos cDNAs coincidem com as estruturas determinadas pelas analises das sequencias das proteinas extraidas de tecidos (Burgess \& Maciag, 1989 ).

As duas proteinas sao codificadas por genes separados, cada um deles representado no genoma por uma única copia (Jaye \& cols., 1986; Abraham \& cols., 1986a, 1986b). A analise da localizacão cromossomal demonstra que o gene para afGF humano está no cromossomo 5 entre as bandas 5q31.J e $5 q 33.2$ (Jaye \& cols., 1986), enquanto o gene para bFGF humano está localizado no cromossomo 4 (Mergia \& cols., 1986) na banda 4q25 (Fukushima \& cols., 1990). Isto sugere que atraves do processo de duplicacăo genica e divergencia evolucionária, as duas proteinas tornaram-se produtos genicos separados (Gospodarowicz \& cols., 1987b).

Ambos os genes contem tres exons separados por dois introns relativamente grandes. O mapeamento por enzimas de restricao de ambos os genes indica que seus tamanhos sâo maiores que $38 \mathrm{~kb}$ (Gospodarowicz \& cols., 1987b; Burgess \& Maciag, 1989).

Em varias culturas de células e tecidos, o gene de bFGF transereve duas especies de mRNAs poliadenilados de 
aproximadamente 3,7 e $7,0 \mathrm{~Kb}$. $\square$ gene de afGF parece codificar uma unica espéie de mRNA de aproximadamente 4,6 Kb (Gospodarowicz \& cols., 1987b).

\subsection{Expressao dos FGFs recombinantea}

FGF recombinante tem sido expresso em celulas de mamifero (Abraham \& cols., 1986c; Kurokawa \& cols., 1987; Rogelj \& cols., 1988; Sasada \& cols., 1988; Blam \& cols., 1988; Neufeld \& cols., 1988; Jaye \& cols., 1988; Prats \& cols., 1989; Florkiewicz \& Sommer, 1989); S. cerevisae (Barr \& cols., 1988) e E. coli (Iwane \& cols., 1987; Jaye \& cols., 1987; Linemeyer \& cols., 1987; Barr \& cols., 1988; Squires \& cols., 1988; Fox \& cols., 1988; Knoerzer \& cols., 1989; Seno \& cols., 1990; Watanabe \& cols., 1990; Ke \& cols., 1990; Thompson \& cols., 1991). Os protocolos de expressă, assim como os objetivos, sao variados.

E. 디 producao em larga escala das proteinas modificadas ou nao por engenharia genetica, uma vez que os fGFs sao polipeptideos de cadeia única, nå sao glicosilados e nåo apresentam ligacós dissulfeto estáveis.

Ds trabalihos descrevem, em geral, que os FGFs sao produtos de baixa (ou nentuma) toxicidade e que podem ser obtidos em grande parte como proteinas solúveis intracelulares. A producăo em escala laboratorial varia com o sistema de expressao utilizado, a forma molecular que está sendo expressa e com a modificacao da sequencia genica codificadora nativa. Ds melhores resultados obtidos (10-50 $\mathrm{mg}$ de FGF por litro de cultura induzida) foram aqueles onde se utilizaram promotores fortes (trp, T7 RNA polimerase), sequencias lider altamente expressas elou sequencias genicas modificadas (Iwane \& cols., 1987; Jaye \& cols., 1987; Squires \& cols., 1988; Watanabe \& cols., 1990; Ke \& cols., 1990; Thompson \& cals., 1991). 


\subsection{Objetivos}

Atualmente, há grande interesse em se estudar os mecanismos de acao dos fGFs a nivel molecular assim como definir seus papeis in vivo. Uma das metas do laboratorio é estudar esses aspectos atraves de proteinas modificadas por manipulacao genetica.

A primeira etapa, objetivo deste trabalho, foi o desenvolvimento de sistemas adequados para a expressao de dois componentes da familia dos FGFs: o bFGF bovino (bbFGF, pI 9-10) e - aFGF humano (haFGF, PI 5-6), atraves de técnicas de DNA recombinante. Essa proposicăo foi subdividida em tres fases: (1) construcão dos vetores de expressao contendo as sequencias genicas adequadas; (2) producao de FGF em escala laboratorial e (3) purificaça e caracterizaça quimica e biologica dos produtos obtidos. 


\section{MATERIAIS E METODOS}

2.1. Vetores - (1) pJC3-5 - contém um fragmento de 475 pares de bases (bP), incluindo a regiao que codifica para o hafgF, inserido nos sitios de NCOI e ECORI do plasmideo pBR329 (Covarrubias, \& Bolivar, 1982). A sequencia deste fragmento corresponde aquela descrita por Jaye \& cols. (1986), com as seguintes modificacôes: (a) alteracăo em um sitio de NcoI sem afetar os codons; (b) o codon de terminacăo foi trocado de TAA para TGA e (c) dois novos sitios de clivagem para as enzimas HindIII e EcoRI foram adicionados em seguida ao codon de terminacao; (2) pJJ11-1 - contem um fragmento de 1,4 Kilobases (Kb) constituido pelo cDNA do gene de bbFGF, cuja sequencia fai descrita anteriormente (Abraham \& cols., 1986a). Este fragmento está inserido no sitio de EcoRI do plasmideo pBR3z2 (Bolivar \& cols., 1977). Estes dois plasmideos foram cedidos pela Dra. J. A. Abraham (California Biotechnology, Inc., CA, USA). Um esquema dos fragmentos contidos nos plasmideos pJJ11-1 e pJc3-5 esta mostrado na Figura 3; (3) pKK233-2 (Pharmacia LKB Biotechnology) - plasmideo de expressao onde as sequencias genicas ficam sob controle do promotor tre (Amann \& Brosius, 1985) - Figura 4.a.; (4) pET-3d (cedido pelo Dr. Fernando de Castro Reinach com a autorizaça do Dr. F. W. Studier - Brookhaven National Lab., NY, USA) - um dos vetores DET (plasmideo para Expressao pela I7 RNA polimerase; Studier \& cols., 1990) - Figura 4.b.; (5) pUC19 (Yanisch-Perron \& cols., 1985) cedida pela Dra. Martha H. Sonabe. 
(a) pJC3-5 (haFGF)

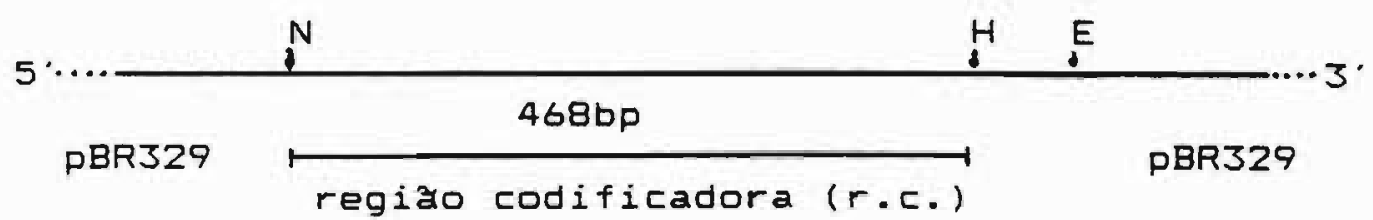

(b) DJJ11-1 (bDFGF)

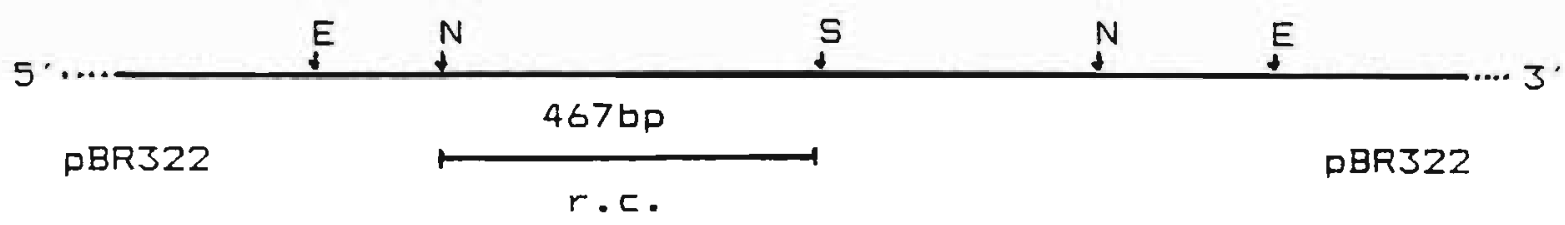

Fiqura 3 . Esquema dos fragmentos de DNA de haFGF $e$ de bbFGF inseridos em pJC3-5 e pJJ11-1 respectivamente. (a) pJC3-5 haFGF+pBR329 e (b) pJJ11-1 - bbFGF+pBR322. N (NCOI); H (HindIII); $E$ (EcORI): 5 (Sau3AI) 


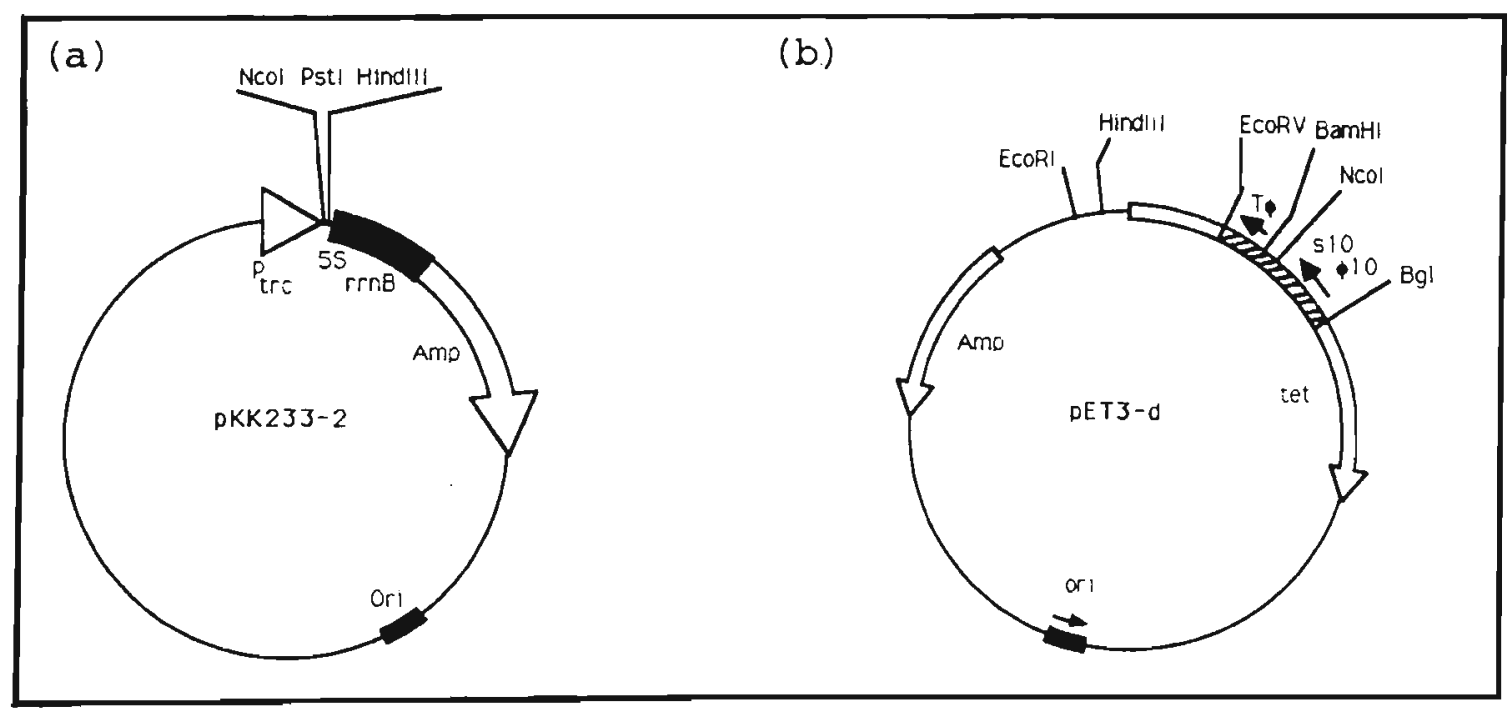

Fiqura 4. Plasmideos de expressao utilizados. (a) pKK233-2 vetor do tipo ATG (Amann \& Brasius, - 1985) derivado de pBR322. Elementos principais: (1) Ptre - promotor hibrido entre os promotores trpe lac; (2) RBS, sitio de ligacao ao ribossomo do gene lac Z; (3) MCS - sitio múltiplo de clonagem; (4) rrnB terminador de transcricao; (5) Amp - gene que confere resistencia a ampicilina. (b) DET-Jd - um dos vetores pET (Studier \& cols., 1990). Principais elementos: (1) Amp - confere resistencia a ampicilina: (2) $\phi 10-510$ - contem um promotor para a T7 RNA polimerase derivado do promotor $\phi 10$ ligado a regiao de iniciacao da traduço da proteina do gene 10; (3) "ATG cloning site" (NCOI); (4) "fusion cloning site" (BamHI) (5) $T \phi-$ terminador de transcricao. 
2.2. Hospedeiros - (1) E. coli cepa HB101 - usada como recipiente em transformacao e para preparacoles em larga escala de plasmideos (Maniatis \& cols., 1982); (2) E. coli K12 cepa JM105 - usada como recipiente em transformacăo por pKK233-2 e pUC19 (Yanisch-Perron \& cols., 1985); (3) E. coli $K 12$ cepa HMS174 (F- recA $r^{-}$ ki2 $\mathrm{m}^{+} \mathrm{k}_{12 R i f R}$ - usada como hospedeiro para clonagem inicial do DNA de interesse em vetores PET e para manutença dos plasmideos (Studier \& cols., 1990); (4) E. coli B cepa BL21 (F- ompTr-am-a) - usada como hospedeiro de expressao, apresenta a vantagem de ser uma cepa B, que é deficiente na protease lon. Tambem nao tem ompt, protease de membrana externa que pode degradar proteinas durante a purificaçăo (Studier \& cols., 1990).

\subsection{Transformacăo de E. coli com DNA plasmidial (Mandel \& Higa, 1970)}

Culturas de E. coli foram preparadas em meio LB (LuriaBertani) até atingir $A_{s o \infty} \simeq 0,3$. As células foram coletadas por centrifugaço (15 minutos, $5.000 \mathrm{rpm}, 40 \mathrm{C}$ ), incubadas em $10 \mathrm{ml}$ de acetato de sodio $10 \mathrm{mM} \mathrm{pH} 6,5$ contendo Cacl= 0,1 M (30 minutos, oo C) e novamente centrifugadas. Os precipitados resultantes foram ressuspensos separadamente, em solucao de acetato de sodio/CaCl= contendo $20 \%$ de glicerol. Alíquotas de 1 $\mathrm{ml}$ contendo as bacterias competentes foram congeladas em $\mathrm{N}=$ liquido e armazenadas a -700 C. Para a transformacão, as bactérias foram descongeladas em banho de gelo por aproximadamente 30 minutos.

Para cada transformaczo tomou-se cerca de $500 \mathrm{ng}$ de plasmideos e misturou-se com 200 ul da suspensao de bacterias competentes em um tubo que foi incubado sucessivamente em bantio de gelo ( 30 minutos), a 370 C ( 5 minutos) e em banho de gelo (10 minutos). A seguir se adicionou $1,0 \mathrm{ml}$ de meio LB aos tubos (suspensão 1 ) e a incubaçao prosseguiu a 370 C por mais 30 minutos. 
Todas as bacterias utilizadas sofreram o mesmo processo de transformaczo, com exceço de E. coli JM105 que antes de ser cultivada para torna-la competente foi ressuspensa em meio LB, incubada por uma noite a $370 \mathrm{C}$, depois plaqueada em meio minimo M-9 contendo 1 ug $\mathrm{ml}^{-1}$ de tiamina e 25 ug $\mathrm{m}^{-1}$ de estreptomicina, e novamente incubada por uma noite a $370 \mathrm{C}$. Este tratamento fai realizado para assegurar a retencăo de $F^{\prime}$ epissomal que é necessário para a infeçáo pelo fago M13 e a complementacáo da Bgalactosidase (triagem azul/branca) (Yanisch-Perron \& cols., 1985).

\subsection{Extraça de DNA plasmidial}

Colenias crescidas em placas LBA (meio LB contendo 1,5\% de agar e antibiotico) foram inoculadas isoladamente em meio liquido LBA $(7 \mathrm{ml})$ e incubadas por uma noite (370 C, sob agitacao). Os inóculos gerados foram transferidos para frascos contendo $400 \mathrm{ml}$ de meio LBA e incubados por uma noite ( $370 \mathrm{C}$, sob agitaçăo). As bacterias foram coletadas por centrifugacao $(4.000 \mathrm{rpm}, 10$ minutos, 40 C), ressuspensas e lavadas por centrifugacăo com $6 \mathrm{ml}$ de tampao GET gelado (Glicose $50 \mathrm{mM}$, EDTA $10 \mathrm{mM}$, Tris-HCl $25 \mathrm{mM}$ $\mathrm{pH}$ 8,0). Os precipitados finais foram ressuspensos em tampao GET gelado ( $4 \mathrm{ml}$, Oo C), tratados com lisozima (1 $\mathrm{ml}$ de solucao $25 \mathrm{mg}$ $m^{-1}$ em tampáo GET) por 5 minutos à temperatura ambiente e depois mantidos em gelo. A seguir, adicionou-se lentamente e sob agitacă $10 \mathrm{ml}$ da salucao de 1 ise ( $\mathrm{NaOH} 0,2 \mathrm{~N} / \mathrm{SDS} 1 \%$ ) incubandose por 10 minutos ( $0^{\circ}$ C); seguiu-se a adicáo de acetato de potássio $3 \mathrm{M} \mathrm{PH} \mathrm{4,8} \mathrm{gelado} \mathrm{e} \mathrm{nova} \mathrm{incubacáo} \mathrm{(0o} \mathrm{C,} 10$ minutos) após o que as suspensáes foram centrifugadas $(15.000 \mathrm{rpm}, 20$ minutos, 40 C). Ao sobrenadante adicionou-se entao 0,6 volume de isopropanol incubando-se por cerca de 2 horas a $22^{\circ} \mathrm{C}$. Is precipitados foram coletados por centrifugaça (25 minutos, $12.000 \mathrm{rpm}, 40 \mathrm{Cl}$ e dissolvidos em $3 \mathrm{ml}$ de TE pH B,O autoclavado previamente (TE=Tris-HCl $10 \mathrm{mM} / E D T A 1 \mathrm{mM} \mathrm{pH} 8,0)$. As suspensoes resultantes foram tratadas com RNase A (tipo I - A, Sigma 


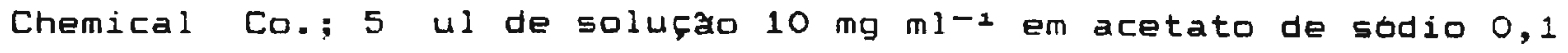
M, EDTA $0,3 \mathrm{M} \mathrm{pH} \mathrm{4,8,} \mathrm{pré-aquecida} \mathrm{a} \mathrm{800} \mathrm{C} \mathrm{por} 10$ minutos), por uma noite a $370 \mathrm{C}$ e logo apos com proteinase K (Merck; 5 ul da suspensão $20 \mathrm{mg} \mathrm{ml}^{-1} \mathrm{em}$ agual por 5 horas a $370 \mathrm{C}$. As solucôes foram desproteinizadas com igual volume de fenol-cloroformio (mistura $1: 1,2$ vezes), coletando-se a fase aquosa apos centrifugaço. As soluços finais (cerca de $3 \mathrm{ml}$ cada uma) adicionou-se $\mathrm{NaCl} 5$ M para concentracá final de $0,2 \mathrm{M}$ e o DNA foi precipitado com etanol $(6,5 \mathrm{ml},-200 \mathrm{C}, 12$ horas). Os precipitados foram lavados com etanal 80\%, coletados por centrifugacão e finalmente secos sob vacuo.

\subsection{Purificaça do DNA plasmidial em C5Cl}

Cscl ( $1 \mathrm{~g}^{\mathrm{ml}} \mathrm{l}^{-1}$, concentracăo final) foi adicionado ás preparacôes de DNA $(3 \mathrm{ml}$ cada). As solucōes resultantes foram transferidas para tubos de polialomero (Beckman). A cada tubo se adicionou $0,3 \mathrm{ml}$ de brometo de etidio (40 $\mathrm{mg} \mathrm{ml}^{-1}$ em água). Os tubos foram equilibrados e centrifugados $(65.000 \mathrm{rpm}, 14$ horas, $200 \mathrm{C}$, rotor VTI-80). As bandas correspondentes aos DNAs plasmidiais foram identificadas iluminando-se os tubos com lampada de luz ultra-violeta (UVS-12) e coletadas furando-se os tubos com agulhas ( $30 \times 7$ ) conectadas em seringas de $1 \mathrm{ml}$ (Maniatis \& cols., 1982). Ds DNAs coletados (cerca de $1 \mathrm{ml}$ para cada preparaço) foram lavados com alcool isoamilico ( $1-2 \mathrm{ml}$ cada vez) até extracao total do brometo de etidio. Posteriormente as solucaes aquosas foram dialisadas contra água bidestilada (3,5 litros, 2 vezes, 10 horas) e TE (3,5 litros, 2 vezes, 8 horas) em camara fria. Finalmente os DNAs foram precipitados com 3 volumes de etanol ( 48 horas, $-20^{\circ}$ C), lavados uma vez por centrifugaça com etanol 80\% e solubilizados em $0,2 \times \mathrm{TE}$. 


\subsection{Mini-preparafoes de plasmideos \\ (Holmes \& Quigley, 1981)}

Uma colonia de bacterias transformadas foi inoculada em 10 $m l$ de meio LBA (ampicilina 50 ug $\mathrm{ml}^{-1}$ ), incubada por uma noite, sob agitaço a 370 C, esfriada a 40 C e centrifugada a $7.000 \mathrm{rpm}$ por 5 minutos. 0 sobrenadante foi removido $e$ o precipitado ressuspenso em $700 \mathrm{ul}$ de tampao STET (Tris-HCl $50 \mathrm{mM}$ pH B,O; EDTA $50 \mathrm{mM} \mathrm{pH} \mathrm{8,0;} \mathrm{Sacarose} \mathrm{8 \% ;} \mathrm{Triton} \mathrm{X-100} \mathrm{5 \% ).} \mathrm{A} \mathrm{suspensao} \mathrm{foi}$ transferida para outro tubo "Eppendorf" e lisozima foi adicionada

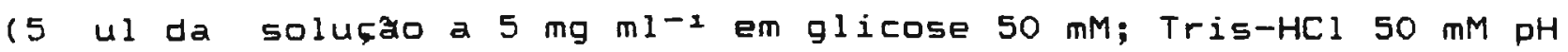
8,0; EDTA $10 \mathrm{mM}$ pH 8,0 recem-preparada). O tubo foi entao incubado por 90 segundos em banho de agua fervente e centrifugado a 12.000 g por 20 minutos a temperatura ambiente; o sobrenadante foi transferido para outro tubo. Adicionaram-se 5 ul de RNase A (acima mencionada) e incubou-se a temperatura ambiente por 15 minutos. A amostra foi desproteinizada por duas vezes, uma com a mistura fenol-cioroformio (1:1) e outra com cloroformio. A fase aquosa resultante, adicionou-se 0,2 volume de acetato de amonio $10 \mathrm{M}$ e 2 volumes de etanol 100\% a 40 C. A amostra foi incubada a -200 C por 12 horas; centrifugou-se a 12.000 g por 20 minutos a temperatura ambiente, e o precipitado de DNA foi lavado com etanol 80\%, seco sob vácuo e ressuspenso em 50 ul de agua.

\subsection{Eletroforese em qel de aqarose}

As preparacoes de DNAs plasmidiais foram analisadas por eletroforese em mini-gel (5,5 cm $\times 7,5 \mathrm{~cm})$ ou em gel (11 cm $x 13$ (m) de agarose preparados a partir de agarose $1 \%$ dissolvida em tampåo $0,5 \times$ TBE (ou $1 \times \operatorname{TBE})(1 \times=\operatorname{Tris-borato~} 0,089$ M; acido bórico 0,089 M; EDTA 0,002 M pH 8,0), contendo brometo de etidio $(0,5$ ug ml-1; Maniatis \& cols., 1982). DNAs de fago $\lambda$ digeridos com BsteI foram utilizados como padrao. As eletroforeses foram realizadas em tampao $0,5 \times$ TBE (ou $1 \times$ TBE), a $60 \mathrm{~V}$; $40 \mathrm{~mA}$, a 
temperatura ambiente. As corridas foram seguidas pela migraça dos corantes azul de bromofenol e xilenocianol.

As bandas de DNA foram visualizadas por trans-iluminacao com lampada UV e fotografadas usando filme Copex Pan (Kodak).

\subsection{Recuperaczo de fragmentos de DNA através de eletroforese sobre membrana de DEAE-celulose (Sambrook \& cols., 1989)}

Uma quantidade de DNA que originava pelo menos $100 \mathrm{ng}$ do fragmento de interesse foi digerida e separada por eletroforese em gel de agarose $1 \%(8,5 \mathrm{~cm} \times 13,0 \mathrm{~cm})$ contendo $0,5 \mathrm{ug} \mathrm{m} \mathrm{m}^{-1}$ de brometo de etidio. A banda de interesse foi entzo localizada com - auxilio de uma lampada UV (UVS-12 MINERALIGHTR). Uma incisao no gel em frente a banda foi feita, usando-se uma lamina. A membrana de DEAE-celulose (Schleicher \& Schull NA-45), tratada previamente com EDTA $10 \mathrm{mM} \mathrm{pH} 8,0, \mathrm{NaOH} 0,5 \mathrm{~N}$ e lavada com agua esteril, foi inserida com auxilio de uma pinca. A eletroforese foi reiniciada ( $5 \vee \mathrm{cm}^{-1}$ ) ate que a banda do DNA tivesse migrado sobre a membrana. A progressão da banda foi monitorada com o auxilio da lampada UV. A membrana foi retirada do gel e lavada rapidamente com 5-10 $\mathrm{ml}$ de tampao de lavagem de baixa concentracao salina (Tris-HCl $50 \mathrm{mM} \mathrm{pH} \mathrm{8,0;} \mathrm{NaCl} 0,15 \mathrm{M}$; EDTA 10 mM $\mathrm{DH}$ 8,O) à temperatura ambiente (este tratamento remove parte da agarose da membrana). A membrana foi entao transferida para um tubo "Eppendorf". Tampáo de eluicao de concentraço salina alta (Tris-HCl $50 \mathrm{mM} \mathrm{pH}$ 8,O; $\mathrm{NaCl} 1 \mathrm{M}$; EDTA $10 \mathrm{mM} \mathrm{pH} \mathrm{8,0)} \mathrm{foi}$ adicionado até cobrir completamente a membrana. Esta foi cuidadosamente dobrada dentro do tubo, que foi fechado e incubado a $650 \mathrm{C}$ por 30 minutos. O líquido foi transferido para um outro tubo e a membrana fai incubada (650 $C$, 15 minutos) cam uma segunda aliquota de tampao de eluiço. As duas aliquotas foram reunidas e tratadas uma vez com fenol-cloroformio (mistura 1:1); a fase aquosa foi transferida para outro tubo, adicionando-se 0,2 volume de acetato de amenio $10 \mathrm{M}$ e 2 volumes de etanol gelado. Incubou-se a mistura por 1 hora a -700 C e recuperou-se o DNA por 
centrifugaça (12.000 g; 20 minutos) em camara fria. Cuidadosamente, o precipitado de DNA foi lavado com etanol 80\% gelado, seco sob vácuo e dissolvido em 5 ul de agua.

\subsection{Reacao de liqase}

Os DNAs do vetor e do fragmento (ver 2.12) foram adicioanados a um tubo esteril. O volume final foi completado para 8 ul com agua. A mistura foi incubada a 450 C por 5 minutos, para fundir formas reaneladas que eventualmente tenham se formado, e resfriada a oo C. Adicionou-se a seguir 1 ulde tampao de enzima 10 vezes concentrado (Maniatis \& cols., 1982), mais 1 ul da enzima T4 DNA ligase (1.000 U ml-1). A reaço prosseguiu por uma noite a temperatura ambiente.

\subsection{Dessalinizacao de oliqonucleotideos sinteticos: cromatogra-} fia de qel-filtracăo em coluna de Sephadex G-25 DNA

Quatro oligonucleotideos, com cerca de 30 bases cada um, foram sintetizados por Wilton J. R. Lima no laboratorio do Dr. Hamza El-Dorry. Estes nucleotideos, correspondiam à extremidade 5. da regizo codificadora de bbFGF, foram usados para substituir cerca de 60 pares de bases do eDNA nativo.

Houve necessidade de dessalinizar os oligonucleotideos. Estes entad foram ressuspensos isoladamente em 400 ul de agua Milli-Q e adicionados em colunas contendo resina Sephadex G25-DNA fina (Pharmacia LKB Biotechnology, $1,1 \mathrm{~cm} x$ 4,5 cm $-5,0 \mathrm{ml}$ ), previamente autoclavada e equilibrada com agua Mili $-Q$. A seguir, as columas foram lavadas 10 vezes com 400 ui de agua Milii-Q por vez, coletando-se todas as amostras eluidas em cada lavagem. Ds oligonucleotideos foram eluidos nas lavagens de mo= $6 \in 7$.

Todo o processo de dessalinizacăo foi realizado a temperatura ambiente. 
(a)

N $5^{\text {. }}$

3. $\mathrm{H}$

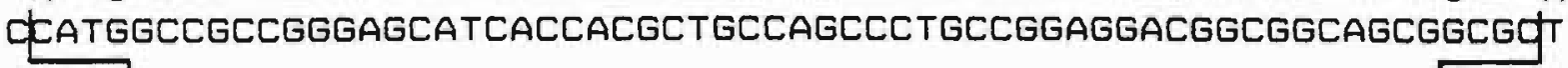

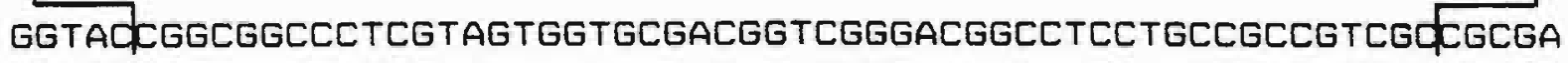
3

(b)

oligonucleotideo 1

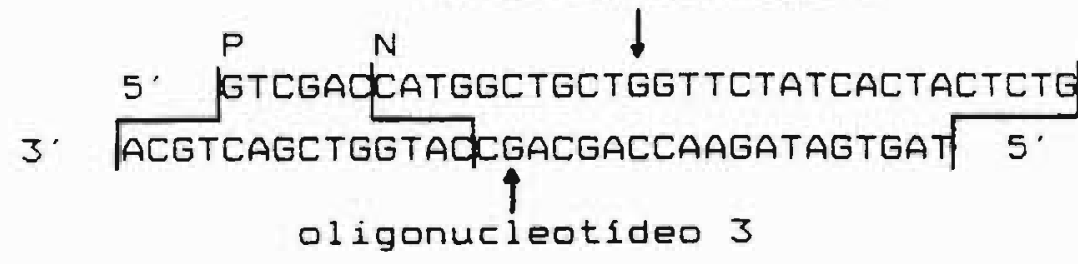

3

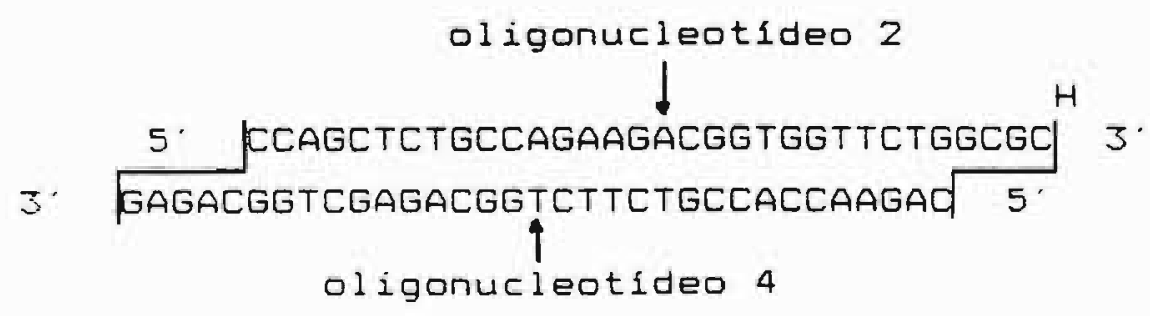

Fiqura 5. (a) Extremidade 5' da regiao codificadora nativa de bDFGF que foi substituida pelos 4 oligonucleotideos sinteticos; (b) Desentio dos 4 oligonucleotideos que foram sintetizados para substituir a extremidade $5^{\prime}$ da regiao codificadora nativa de bDFGF. P (PstI); N (NCOI); H (HaeII) 


\subsection{Hibridizacao e fosforilacao dos oliqonucleotideos}

Como mostra a Figura 5.b, houve necessidade de hibridizar o oligonucleotideo 1 com $\square 3$ e 02 com 0 4, para substituir a extremidade $5^{\prime}$ da regiao codificadora nativa do bbFGF (Figura 5.a). Para tanto, foram misturadas quantidades equimolares dos oligonucleotideos correspondentes (120 uM), que foram aquecidas a 800 C num becker e esfriadas até a temperatura ambiente. Estes fragmentos de DNA de dupla fita assim formado foram denominados oligonucleotideo $(1+3)$ e oligonucleotideo $(2+4)$. Em uma das extremidades do oligonucleotideo $(1+3)$ formou-se um sitio de restricao para Psti; a outra é coesiva com uma das extremidades do oligonucleotideo $(2+4)$. Uma das extremidades do oligonucleotideo (2+4) tem um sitio de clivagem para HaeII (Figura 5.b).

Após a hibridizacao, as extremidades 5 das duplas fitas formadas foram fosforiladas. Adicionaram-se, respectivamente, a tubos estereis: 2 ul de oligonucleotideos (120 pmols), 2 ul de tamparo quinase $10 \times$ concentrado, 1 ul de DTT $100 \mathrm{mM}, 1$ ul de ATP $10 \mathrm{mM}, 12 \mathrm{ul}$ de agua bidestilada, 1 ul de polinucleotideoquinase

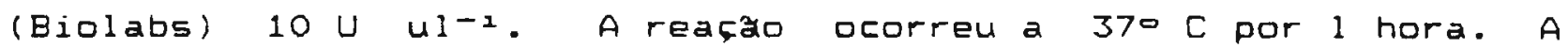
enzima foi entao inativada (650C, 10 minutos) (Carter, 1987).

\subsection{Estrateqias utilizadas para subclonaqens}

\subsubsection{Subclonagem de haFGF em pKK233-2}

(1) o fragmento de DNA de haFGF (468 bp), retirado de pJC3-5 (Figura 3.a) atraves de digestao com Ncol e HindII, foi recuperado conforme descrito em 2.8; (2) o vetor pKK233-2 foi tambem digerido com as mesmas enzimas; (3) o fragmento de hafGF e - vetor pKK233-2, digeridos com Ncol e HindIII, foram ligados atraves de suas extremidades coesivas com a enzima T4 DNA ligase, conforme descrito em 2.9 . 
A proporcă vetor:inserto utilizada nesta subclonagen foi de 1:10. Na proporcăo usualmente recomendada 11 de vetor:1 de fragmento) nao foram obtidos transformantes (Sambrook \& cols., 1989).

\subsubsection{Subclonagem de haFGF em PET-3d}

(1) igual 1tem (1) de 2.12.1; (2) a vetor PET-3d foi digerido com NcoI e HindII, liberando um fragmento de tamanho (PM) semelhante ao do inserto (haFGF) (Figura b); (3) o "vetor" PET-3d (NCOIHindIII) foi isolado do fragmento menor, conforme descrito em 2.8; (4) o fragmento de haFGF e o "vetor" PET-3d foram ligados atraves de suas extremidades coesivas com a enzima T4 DNA ligase, conforme mostrado em 2.9.

As proporcoes vetor:inserto utilizadas nesta reacao de ligaça foram: (a) $1: 1$; (b) $1: 3$; e (c) $1: 5$ (Tabela V).

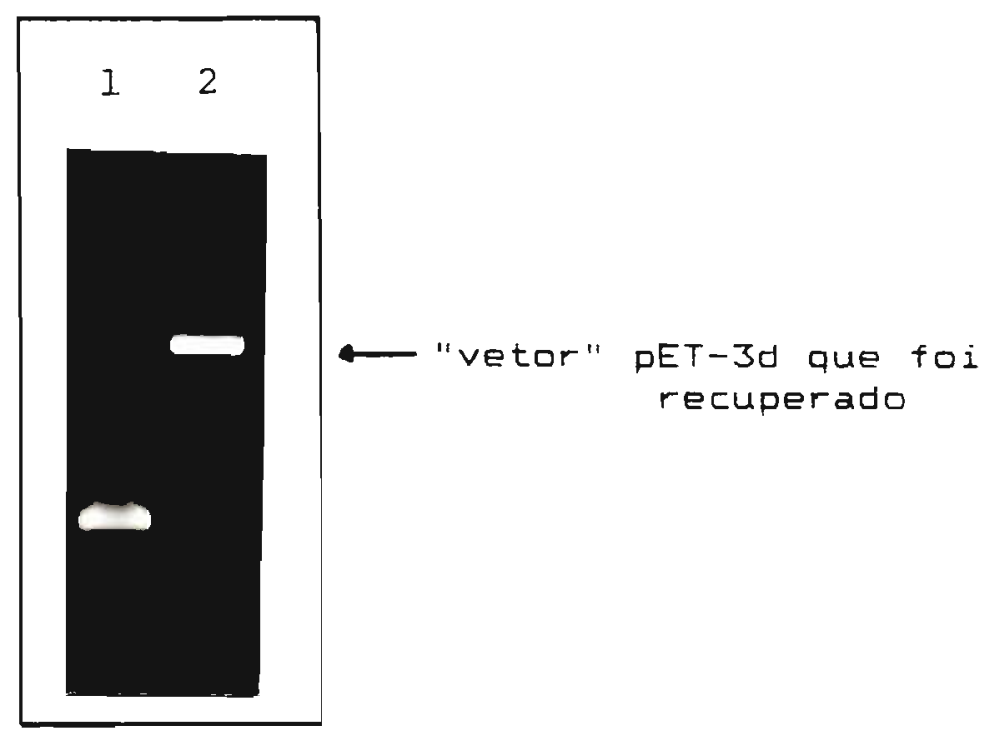

Figura 6. Eletroforese de pET-3d e do fragmento de hafGF apds digestao com NcoI-HindIII. Poco 1 - hafgF (NcoI-HindIII); Poco 2 - pET-3d (NcoI-HindIII). Foi aplicado 1 ul de cada amostra. 


\subsubsection{Subclonanem de bbFGF em PET-3d}

(1) O fragmento de DNA de bbFGF de 1,4 Kb (Figura 7), retirado de PJJ11-1 atraves de digestao com EcoRI, foi recuperado conforme descrito em 2.B - fragmento EcoRI-EcoRI; (2) Este fragmento foi digerido com HaelI, recuperando-se o fragmento de $1,2 \mathrm{~Kb}$ pelo mesmo metodo - fragmento HaeII-EcoRI; o fragmento NcoI-HaeII (Figura 7) foi substituido pelos oligonucleotideos $(1+3)$ e $(2+4)$ do ftem 2.11 (Figura 5.b); (3) a vetor puc19 foi digerido com PstI e EcoRI; (4) A reaça de ligase foi realizada juntando-se o fragmento HaeII-EcoRI $(7,6$ pmols), 0 oligonucleotideo (1+3) fosforilado $(7, \theta$ pmols), O oligonucleotideo (2+4) fosforilado $(7,8$ pmols) e o pUC19 digerido com Psti e EcoRI (2,8 pmols). Estes foram ligados atraves de suas extremidades coesivas com a enzima T4 DNA ligase, conforme mostrado em 2.9 ; (5) 0 novo plasmideo assim formado (pUC19+bbFGFmodif. - denominado pAUXB-1) foi digerido com NcoI liberando um fragmento de aproximadamente $1,0 \mathrm{~Kb}$ - fragmento NcoI-Ncol, que foi recuperado pelo metodo acima mencionado; (6) Este fragmento foi digerido com Sau3AI, gerando 3 fragmentos: fragmento NcoI-Sau3AI (466 bp) contendo a sequencia codificadora; fragmento Sau3AI-5au3AI (19 bp) e fragmento Sau3AI-NCOI (561 bP); (7) O vetor pET-3d foi digerido com NcoI e BamHI; (B) A reacao de ligase foi realizada misturando-se os fragmentos gerados em ( 6 ) com o vetor PET-3d (da etapa 7). Um esquema desta subclonagem está mostrado na figura 8 .

As proporcoues vetor:inserto utilizadas nesta reacao de ligacao foram: (a) $1: 1$; (b) $1: 3$; e (c) $1: 5$.

0 bbFGFmodif. foi subclonado em pUC19 para posterior sequenciamento da porça de DNA modificada. 


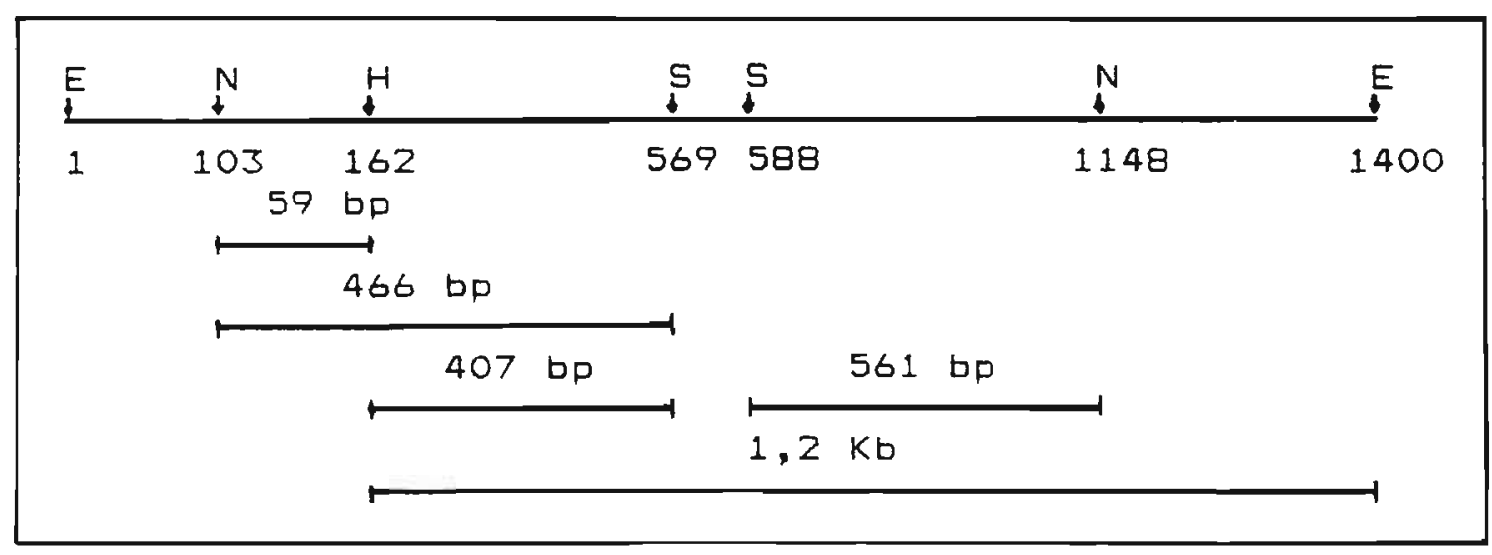

Fiqura 7. Principais sftios de restricá do CDNA nativo de bbFGF. Fragmento $\mathrm{N}-\mathrm{H}$ ( $59 \mathrm{bP}$ ) - porçăo que foi substituida pelo DNA sintético (confira Figura 8); Fragmento N-5 (466 bp) - regiao codificadora. E (EcoRI); N (NcoI); H (HaeII); S (SauBAI). 


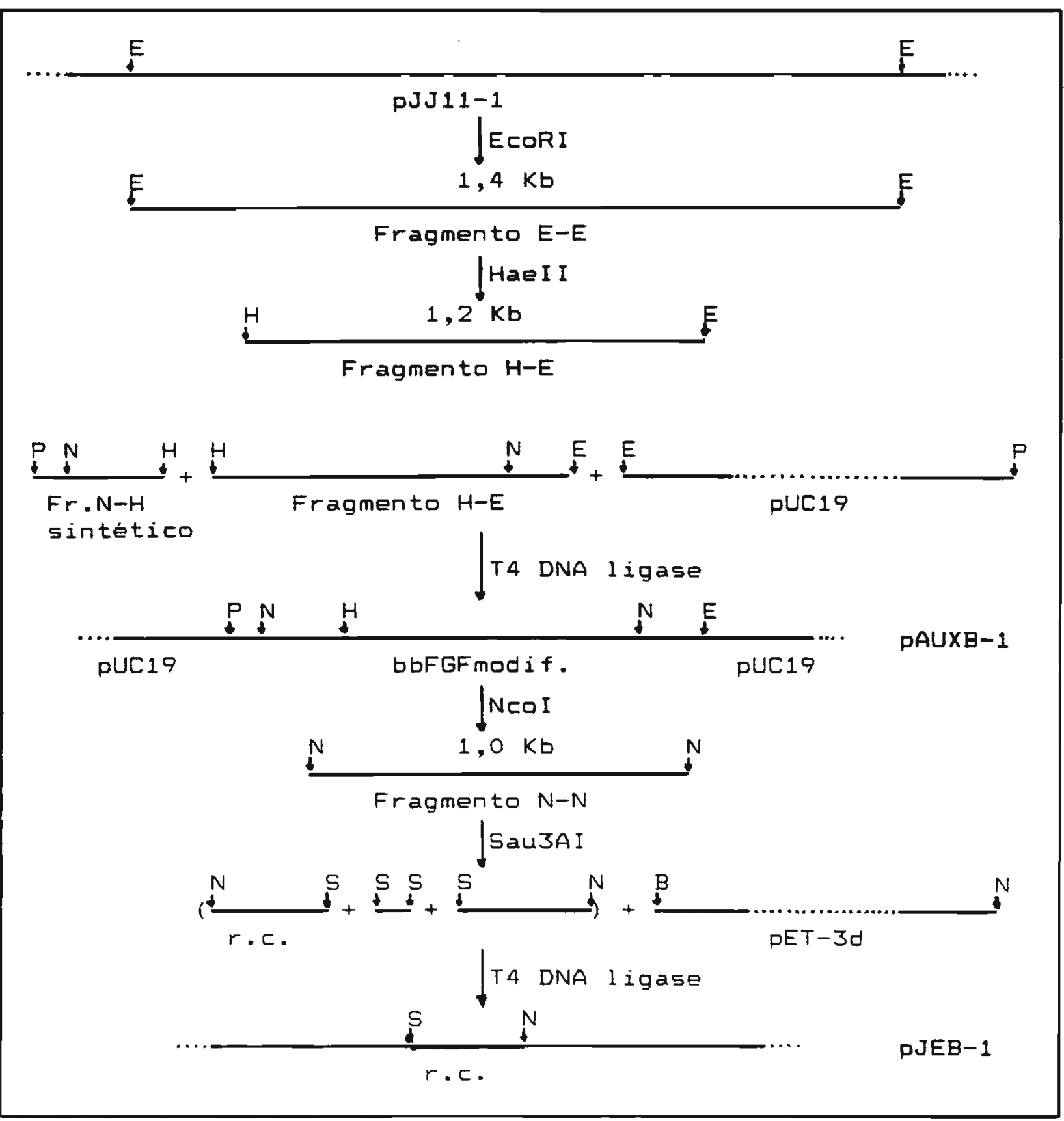

Fiqura 8. Esquema de subclonagem de bbFGF em DET-3d. Os sitios de restricao de BamH e de saujaI 5ao coesivos. E (EcoRI), H (HaeII), P (PstI), N (NeoI), S (SauBAI), B (BamHI), r.c. (regiao codificadora). 


\subsection{Sequenciamento de DNA}

- sequenciamento de DNA foi realizado pelo método de terminacao de cadeia por dideoxinucleotideo (sanger \& cols., 1977 ).

Utilizando o vetor pAUXB-1, a extremidade $5^{\circ}$ da regiao codificadora do CDNA modificado de bbFGF foi sequenciada utilizando-se o plasmideo dupla fita. Primeiramente, o DNA plasmidial foi desnaturado conforme Lim \& Pene (1988) e a seguir procedeu-se de acordo com o protocolo descrito no catalogo que acompantia o "T7 Sequencing Kit" (Pharmacia LKB Biotechnology).

\subsection{Eletroforese de sequenciamento de DNA}

- gel foi montado en sistema de sequenciamento Bio-Rad SEQGEN, conforme especificacoes do fabricante. Para cada gel de 50 $\mathrm{cm} \times 20 \mathrm{~cm}$ foram utilizados $50 \mathrm{ml}$ de gel desnaturante ( $5 \%$ de mistura acrilamida-bisacrilamida $(19: 1), 1 \times$ TBE 1219 de uréia).

As placas foram fixadas utilizando espacadores com espessura variando de $0,20 \mathrm{~mm}$ a $0,75 \mathrm{~mm}$ (do topo para a base do gel).

0 gel foi colocado entre as placas presas e estas foram deixadas na posicao horizontal por 45 minutos para polimerizacao. Apos este perfodo, o gel foi submetido a uma précorrida de 1 hora na potencia de $40 \mathrm{w}$ e a $50^{\circ} \mathrm{C}$. Amostras de 2 ul de cada reacao foram entao aplicadase a eletroforese prosseguiu por 2 horas nas mesmas condiçes da pre-corrida. O gel aderido a uma das placas foi entao fixado em solucao de acido acético:metanol:agua $(1: 1: 8)$ por 20 minutos a temperatura ambiente, transferido para papel $3 M M$ e coberto com uma pelicula de plastico para secagem sob vacuo a $800 \mathrm{C}$. Depois de seco, 0 gel foi exposto contra filme de raio $x$ (Kodak $x$-Omat). 


\subsection{SDDS-PAGE \\ (LaemmI i, 1970)}

A eletroforese foi realizada num gel de separaça $15 \% T$ e $2,67 \% \mathrm{C}$, de $5,0 \mathrm{~cm}$ de comprimento, a $20 \mathrm{~mA} e 45 \mathrm{~V}$, por aproximadamente 2,5 horas a temperatura ambiente. 0 gel de empilhamento utilizado (1,0 cm de comprimento) tinha a composicao de $3 \% T$ e $2,67 \%$ C.

\subsection{Western-Blotting}

A transferencia das fraçós proteicas do gel de poliacrilamida-5DS para a membrana de nitrocelulose (Schleicher \& Schull BAB5 $0,45 \mathrm{um}$ ) foi feita por aproximadamente 14 horas a 60 $m A$ em camara fria, em tampáa de transferencia (Tris-Base $10 \mathrm{mM}$, Glicina $150 \mathrm{mM}$, Metanol 20\%). Logo apos a transferencia, a membrana com as fracóes proteicas foi corada com Ponceau $50,1 \%$ em ácido acetico $10 \%$ e fotografada.

A reaço com anticorpos anti-afGF foi feita como descrita abaixo: (1) Os sftios inespecificos foram bloqueados, incubandose a membrana com $0,3 \%$ de gelatina (Colágeno Tipo I I de pele de porco - Sigma) em PBSA sob agitacao ( 2 horas, temperatura ambiente); (2) 0 antisoro (anti-afGF $Y-34-A$ - doado pelo Dr. W. Mckeehan - W. Alton Jones Cell Science Center, N.Y., USA) diluido a 1:250 (em PBSA; gelatina $0,3 \%$ ) foi incubado por uma noite a 40 c e depois por 1 hora à temperatura ambiente; (3) Lavou-se com a solucao de lavagem (gelatina 0,3\%, Tween 20 (Riedel) $0,05 \%$ em PBSA) a temperatura ambiente, sob agitacao, por 1 hora (4 trocas de solucao;; (4) Incubou-se com o conjugado fosfatase alcalinaIgG ("Anti-rabbit IgG", Sigma $n^{\circ} 8025$ ) dilufdo em Tris-HCl $100 \mathrm{mM}$ pH 9,5; NaCl $100 \mathrm{mM}$; MgCl= 5 mM (solucao diluente) por 1 hora, sob agitacao à temperatura ambiente; (5) Lavou-se com a solucao de lavagem descrita acima por 1 hora (4 trocas, sob agitaça). Para a revelaczo, a solucao de lavagem foi removida totalmente, lavou-se novamente com a solucao diluente e entao adicionaram-se 
33 ul de BCIP (5-Bromo-4-Cloro-3-Indolil-Fosfato) $50 \mathrm{mg} \mathrm{ml}^{-1}$ e 66 $u l$ de NBT (Nitroblue Tetrazolium) $50 \mathrm{mg} \mathrm{ml}^{-1}$ em $10 \mathrm{ml}$ de diluente. A reacao positiva originou bandas de cor azul-violeta após 10 minutos de incubacao; (6) Finalmente a reacao foi interrompida, lavando-se varias vezes com agua.

\subsection{Sistema de expressao usando vetor pKK (Amann \& Brosius, 1985)}

Estes vetores tem promotores de fusao trp-lac (trc) fortemente regulados e a sftio de ligacáo ao ribossomo (RBS) de lacz seguido do codon de iniciaça de traduça ATG, onde começa o sitio múltiplo de clonagem (MCS) (Figura 4.a).

- promotor tre tem espacamento de 17 pares de bases entre a regiao -35 de trp e a regiao -10 de lacuvs. 0 codon de iniciaça de traduczo ATG esta localizado em um único sitio de restricao Ncol. A regiao de clonagem é seguida por terminadores de transcricao rrnB.

Estes vetores podem ser utilizados em varios casos: (1) diretamente para gene em que o sitio NCOI coincide com seu codon de iniciacao; (2) por ligacao abrupta de fragmentos onde o sitio NeoI do vetor foi preenchido; (3) correcáo da fase de traducaao por adiço de ligantes Ncol de tamanho apropriado; (4) inserço de cDNA.

\subsection{Sistema de expressao usando vetor pET}

(Studier \& cols., 1990)

A RNA polimerase do bacteriofago $T 7$ é bem seletiva para promotores especificos que raramente sao encontrados em DNAs nao relacionados ao DNA de T7. Sinais de terminaçăo são também raros, de modo que a T7 RNA polimerase transcreve completa e eficientemente a maioria dos DNAs que e colocada sob controle do promator T7. A T7 RNA polimerase é uma enzima muito ativa e alonga as cadeias cerca de cinco vezes mais rapidamente do que a 
RNA polimerase de E. Eoli. Em alguns casos, transerif̧a pela T7 RNA polimerase é tao intensa que a RNA polimerase bacteriana aparentemente nao consegue competir. Sob circunstancias favoraveis, os recursos da celula sao dirigidos quase que inteiramente para a producao de RNAs a partir de promotores reconhecidos pela T7 RNA polimerase. Este sistema e capaz de expressar uma grande variedade de DNAs tanto de origem procariótica como eucariótica.

A bacteria E. coli BL21(DE3) e lisogenica para o fago DE3 (derivado de $\lambda$ ). Alem da regiao de imunidade, ele carrega um fragmento de DNA contendo o gene lacI, o promotor lacUVS, o comeco do gene lacz e o gene para a T7 RNA polimerase. Este fragmento está inserido no gene int. Em E. coli BL21(DE3) o promotor lacUV5, induzivel por IPTG (Isopropil B-Dtiogalactosfdeo - Sigma), controla a transcricao do gene da T7 RNA polimerase que, por sua vez, transcreve o DNA de interesse inserido nos plasmideos de expressao PET que sao usados para transformar esta bactéria. Tais vetores foram construldos a partir de pBR3Z2 onde o promotor T7 foi inserido no sitio BamHI em sentido anti-horário, oposto ao do promotor tet. Conferem resistencia à ampicilina (Figura 4.b). Os vetores pET permitem expressar tanto o hafGF como o bbFGF a partir do ATG inicial, presente no cDNA, ou entáo como uma pequena proteina de fusaa. A primeira alternativa foi a escolnida para ambas proteinas.

\subsection{Inducza da expresszo de proteinas em E. coli}

\subsubsection{Induczo da expressao de haFGF utilizando pKK233-2}

Uma cultura de E. coli JM105 transformada com o vetor contendo o inserto de hafGF foi incubada em meio LBA (ampicilina 100 ug $m^{-1}$ ) a 370 C com agitaçao até a fase "midi-log" (Aoso $0,3-0,4)$. IPTG foi entao adicionado para concentracáo final de 1 $\mathrm{mM} e$ a suspensao foi incubada por mais 4 horas, a $370 \mathrm{C}$ com agitacăo (Sambrook \& cols., 1989). 


\subsubsection{Induczo da expressăo de haFGF e bbFGF utilizando pET-3d}

A cultura de E. coli BL21(DE3) transformada com seu respectivo vetor foi incubada em meio LBA (ampicilina $50 \mathrm{ug} \mathrm{m}^{-1}$ ) a $370 \mathrm{C}$, sob agitaça, até que a Asoo atingisse valores entre 0,7 e 1,0. IPTG foi adicionado para concentraço final de $0,4 \mathrm{mM}$ e a incubacao prosseguiu por mais 3 horas (Studier \& cols., 1990).

\subsection{Preparaçán das amostras de proteinas}

\subsubsection{Mini-preparaçoes de proteinas}

Para a verificacăo inicial do nivel de expressao da proteina partiu-se de $5 \mathrm{ml}$ de cultura bacteriana. Antes da inducăo removeu-se $1 \mathrm{ml}$ de cultura para um tubo "Eppendorf" que foi novamente incubado por mais 4 horas ( 3d). Centrifugou-se entao por 1 minuto a $12.000 \mathrm{~g}$. O sobrenadante foi removido por aspiraço e o precipitado, ressuspenso em $100 \mathrm{ul}$ de tampão de amostra para SDS-PAGE (seg. Laemmli), foi aquecido por 3 minutos em banho-maria fervente e centrifugado novamente (12.000 g por 1 minuto à temperatura ambiente). Esta amostra foi usada como controle näo induzido. Aos $4 \mathrm{ml}$ restantes da suspensalo bacteriana IPTG foi adicionado conforme descrito em 2.19. Ao final do periodo de incubacá (4 horas para pKkz33-2 e 3 horas para pET-3d), procedeu-se como descrito acima para o controle nå induzido, removendo-se $1 \mathrm{ml}$ de cultura bacteriana induzida para outro tubo "Eppendorf" (Sambrook \& cols., 1989; Studier \& cols., 1990).

Antes de ser aplicada no gel de poliacrilamida-SDs, a amostra foi novamente aquecida ( 3 minutos, banho-maria fervente). 


\subsubsection{Preparacao das amostras de proteinas em larqa escala utilizando vetor pET-3d}

Partiu-se de 3-5 litros de cultura bacteriana, a qual foi tratada conforme descrito em 2.19.2. As bacterias foram coletadas por centrifugaça (7.000 rpm, $10 \mathrm{minutos,} 40 \mathrm{C}) \mathrm{e} 0 \mathrm{~s}$ precipitados bacterianos foram ressuspensos em tampao fosfato (TF) $10 \mathrm{mM}$ pH 7,2 contendo $5 \mathrm{mM}$ de EDTA (20 $\mathrm{ml}$ para cada litro de cultura bacteriana induzida) e congelados por uma noite a -700 C. A seguir, as bacterias foram descongeladas e mantidas a 40 C; após a adiço de PMSF (Phenylmethane Sulfonyl Fluoride, concentrafao final 500 $n M$ ) foram rompidas numa "French Press" ( 4 passagens a 16.000 psil. A suspensao resultante foi centrifugada a $15.000 \mathrm{rpm}$ por $30 \mathrm{minutos,} \mathrm{o} \mathrm{sobrenadante} \mathrm{foi} \mathrm{coletado} \mathrm{e} \mathrm{o}$ precipitado reextraido com TF $10 \mathrm{mM}$ pH 7,2 contendo $\mathrm{NaCl} 2,5 \mathrm{M}$. Os dois sobrenadantes foram reunidos e a concentrafăo final de NaCl foi ajustada para aproximadamente $0,5 \mathrm{M}$ com a adiça de TF $10 \mathrm{~mm}$ pH 7,2. O precipitado final foi descartado.

\subsection{Cromatografia de afinidade em coluna de Heparina-Sepharose (HS)}

- material solúvel obtido conforme descrito acima foi adicionado, com o auxilio de bomba peristáltica, a uma coluna de Heparina-Sepharose CL-6B (Pharmacia, $2,5 \mathrm{~cm} \times 4,0 \mathrm{~cm}$ ) previamente equilibrada (TF $10 \mathrm{mM}$ pH 7,2 / $\mathrm{NaCl} 0,5 \mathrm{M}$ para hafGF $\mathrm{e}$ TF $10 \mathrm{mM}$ $\mathrm{pH} 7,2$ / NaCl $0,6 \mathrm{M}$ para bbFGF).

Para hafGF, a eluicao foi realizada segundo duas metodologias: (1) gradiente de NaCl por etapas - a coluna foi inicialmente eluida com TF $10 \mathrm{mM} \mathrm{pH} \mathrm{7,2/} \mathrm{NaCl} 0,5 \mathrm{M}$ (37 fracaes de $10 \mathrm{ml}$ cada, ate $\left.A_{20}=0,0\right)$, depois com TF $10 \mathrm{mM} \mathrm{pH} 7,2 / \mathrm{NaCl}$ 1.5 M (30 fraçâs de $5 \mathrm{ml}$ cada, até $A_{2 e s=0,0)}$ e finalmente com TF $10 \mathrm{mM} p H \quad 7,2 / \mathrm{NaCl} 2.5 \mathrm{M}(10$ volumes, ate $A=a s=0,0) ; e(2)$ gradiente linear de NaCl - a coluna foi inicialmente eluida com TF $10 \mathrm{mM} \mathrm{pH} \mathrm{7,2} \mathrm{/} \mathrm{NaCl} \mathrm{0,5} \mathrm{M} \mathrm{("Batch"} \mathrm{ate} \mathrm{Azer=0,0),} \mathrm{depois} \mathrm{com}$ TF $10 \mathrm{mM}$ oH 7,2 / NaCl $0,7 \mathrm{M}$ (17 fracóes de 10 mi cada, ate 
$\left.A_{z e 0}=0,0\right)$. Um gradiente 1 inear de $\mathrm{NaCl}(0,7 \mathrm{M}$ a $1,8 \mathrm{M})$ foi entao aplicado $(50 \mathrm{ml}$ de cada soluçao, em TF $10 \mathrm{mM} \mathrm{pH} 7,2$ - 20 fraçes de $5 \mathrm{ml}$ cadal. Depois, a coluna foi eluida com $T F 10 \mathrm{mM} \mathrm{pH} 7,2$ / $\mathrm{NaCl} 1,8 \mathrm{M}\left(20\right.$ fraçes de $5 \mathrm{ml}$ cada, ate $\left.A=0_{0}=0,0\right)$ e finalmente com TF $10 \mathrm{mM} \mathrm{pH} \mathrm{7,2/} \mathrm{NaCl} 2,5 \mathrm{M}\left(10\right.$ volumes, ate $\left.A_{200}=0,0\right)$.

Quanto ao bbFGF, a eluiço foi realizada apenas por gradiente linear de NaCl. A coluna foi inicialmente eluida com TF $10 \mathrm{mM} \mathrm{pH} \mathrm{7,2} \mathrm{/} \mathrm{NaCl} 0,6 \mathrm{M}$ ("Batch", ate Azes=0,0), depois com TF $10 \mathrm{mM} \mathrm{pH} \mathrm{7,2,} \mathrm{NaCl} 1,0 \mathrm{M}$ (30 fracós de $10 \mathrm{ml}$ cada, ate Azeo $=0,0)$, e entzo o gradiente linear de $\mathrm{NaCl}(1,0 \mathrm{M}$ a 2,5 M) foi aplicado $(50 \mathrm{ml}$ de cada solucăo, em TF $10 \mathrm{mM}$ pH 7,2 - 20 fraçes de $5 \mathrm{ml}$ cada). Por fim, a coluna foi eluida com $T F 10 \mathrm{mM} \mathrm{pH} \mathrm{7,2}$ I NaCl 2,5 M (10 volumes, ate $A=00=0,0)$.

- fluxo utilizado para a eluicao dos dois fGFs nao ultrapassou $0,8 \mathrm{ml}$ min.-1.

\subsection{Ensaios de atividade biológica}

Fibroblastos das Iinhagens Swiss $3 T 3$ e Balb/c $3 T 3$ foram utilizados. Estoques celulares foram mantidos em garrafas plasticas contendo meio DME com $10 \%$ de FCS e uma mistura de $5 \%$ de $\mathrm{CO}=+95 \%$ de ar comprimido.

A partir dos estoques, suspensóes celulares contendo $2,0 \mathrm{X}$ $10^{4}$ Células $\mathrm{ml}^{-1}$ de meio DME com $5 \%$ de fCS foram obtidas por tripsinizacao. Adicionou-se $1 \mathrm{ml}$ por placa (bandejas de 24 placas de $1,5 \mathrm{~cm}$ de diametro, Costar) e incubou-se a $370 \mathrm{C}$ por 24 horas. A seguir, as células foram lavadas com PBS ( $1,5 \mathrm{ml}$ - 2 vezes para Swiss $3 T 3$ ou $2,0 \mathrm{ml}$ - 1 vez para Balb/c 3T3) e incubadas por 48 horas em $0,5 \mathrm{ml}$ de meio DME contendo 0,2\% de FCS (Swiss 3T3) ou $0,5 \%$ de FCS (Balb/c 3T3). Aliquotas das amostras foram entao adicionadas e a cultura foi mantida por 12 horas a $370 \mathrm{C}$. [ $=\mathrm{H}-$ metil] Timidina $\left(0,5\right.$ uCi $\mathrm{ml}^{-1}$ e $2.0 \times 10^{-7}$, concentraçăo final) foi entao adicionada e a amostra foi incubada por mais 12 horas a 370 C. No final, o meio foi eliminado por suçăo e as células tratadas com TCA $5 \%(40$ C, 5 minutos) e lisadas com $0,2 \mathrm{ml}$ de 
$\mathrm{NaOH} 0,5 \mathrm{~N}$ (30 minutos, $500 \mathrm{C}$ ). Os lisados foram adsorvidos em filtros de papel Whatman no $17(1,5 \mathrm{~cm} \times 1,5 \mathrm{~cm})$, lavados com TCA $5 \%$ gelado, etanol 95\% e acetona. Depois de secos, os filtros foram mergulinados em liquido de cintilacao e a radioatividade incorporada no DNA foi medida num espectrometro de cintilacao 1 iquida.

A atividade das amostras (\% R) foi calculada considerando-se como máximo de atividade (100\% R) controles estimulados com $5 \%$ de FCS (Swiss 3T3) e 10\% de FCS (Balb/C 3T3).

2.23. Dosagem de proteina

(Bradford, 1976)

As amostras foram preparadas e analisadas conforme procedimento para microensaios descrito no manual de instruçes do "Bio-Rad Protein Assay (BID-RAD Laboratories)". 


\section{RESLILTADOS}

\subsection{Transformacazo de E. coli}

Todas as transformacôes de bacterias com plasmideos foram realizadas conforme descrito (2.3).

A seleczo dos transformantes foi feita por crescimento clonal em placas de $5,0 \mathrm{~cm}$ de diametro contendo meio LBA. Partiu-se de duas suspensoes: Suspensao 1 (descrita em MATERIAIS E METODOS) e Suspensão 2 (suspensao 1 aproximadamente vinte vezes concentrada). Plaquearam-se cerca de 50 ul de cada suspensao. Os resultados estao ilustrados na Tabela 1.

Foram feitos controles: (1) plaqueando-se as bacterias transformadas (suspensao 1 ) em placa sem antibibtico: houve grande crescimento de colonias; (2) plaqueando-se as bacterias nåo competentes em placas com (LBA) e sem (LB) antibiotico: nå houve crescimento de colenias na placa LBA, enquanto as bactérias eresceram normalmente na placa LB.

Tabela I. Selecáo de bacterias transformantes em placas LBA.

\section{Número de colonias}

\begin{tabular}{|c|c|c|}
\hline Plasmideo & suspensar & suspensão 2 \\
\hline pJJ11-1 (E. 디i HB101) & 9 & 153 \\
\hline PJCZ-5 (E. 든 HB101) & 23 & 160 \\
\hline pKK233-2 (E. 디i JM105) & 1500 & incontáveis \\
\hline pET-3d (E. Eoli HMS174) & 36 & 500 \\
\hline
\end{tabular}

Suspensăo 1 - proveniente da reacao de transformacao bacteriana $(1,2 \mathrm{ml})$; Suspensao 2 - suspensão 1 aproximadamente vinte vezes concentrada. 


\subsection{Extraça e purificacao de DNA plasmidial}

A extracáo de DNA plasmidial foi realizada conforme descrito em "MATERiais e Metodos".

A concentraça de DNA plasmidial mostrada na Tabela I I fai estimada pela $A z \infty 0$ (utilizou-se $A z \infty 0_{1}=1$ equivalente a 50 ug de DNA $m^{-1}$, Maniatis \& cols., 1982). As absorbancias foram obtidas com - DNA solubilizado em TE PH 7,5.

Tabela II. Concentraçao de DNA plasmidial estimada após extraça.

\begin{tabular}{lccc} 
& \multicolumn{1}{c}{ Concentracáo de DNA plasmidial } \\
DNA & $\mathrm{mg} \mathrm{ml-1}$ & Total $(3 \mathrm{ml})$ & $A_{200} / A_{2=0}$ \\
DJJ11-1 & 11,6 & $34,8 \mathrm{mg}$ & 2,25 \\
DJC3-5 & 11,1 & $33,3 \mathrm{mg}$ & 2,26 \\
DKK233-2 & 7,3 & $21,9 \mathrm{mg}$ & 2,08 \\
PET-3d & 4,9 & $14,7 \mathrm{mg}$ & 2,06
\end{tabular}

A contaminacao por proteinas foi estimada pela relacao AzoolAza:. A relacao de absorbancias em torno de 2 indica preparacaes de baixa contaminacao por proteinas. Estas preparacaes foram entao submetidas à purificacao em gradiente de cloreto de césio, conforme descrito em "MATERIAIs $E$ Metodos". Apds extraça do brometo de etidio (com alcool isoamilico) e dialise, os DNAs na forma "supercoil" foram precipitados com etanol 100\% (por uma noite, -200 C), lavados uma vez com etanol 80\% por centrifugacão e solubilizados em $0,2 \times \mathrm{TE} \mathrm{pH} 7,5$.

Foram feitas novas medidas de concentraço de DNA plasmidial (forma "supercoil" - Tabela III) e realizou-se eletroforese em gel de agarose para verificacáo da qualidade do plasmideo extraido (Figura 9). 
Tabela III. Concentraçao de DNA plasmidial (forma "supercoil") após purificacăo em gradiente de cloreto de césio.

$\begin{array}{lccc} & & \text { Quantidade de DNA } & \\ \text { DNA } & \mathrm{mg} \mathrm{ml-1} & \text { Total }(0,5 \mathrm{ml}) & \text { Azoo/Az=0 } \\ \text { PJJ11-1 } & 1,53 & 0,77 \mathrm{mg} & 2,17 \\ \text { PJC-3-5 } & 1,66 & 0,83 \mathrm{mg} & 2,17 \\ \text { PKK233-2 } & 1,60 & 0,80 \mathrm{mg} & 2,09 \\ \text { PET-3d } & 3,20 & 1,60 \mathrm{mg} & 2,08\end{array}$

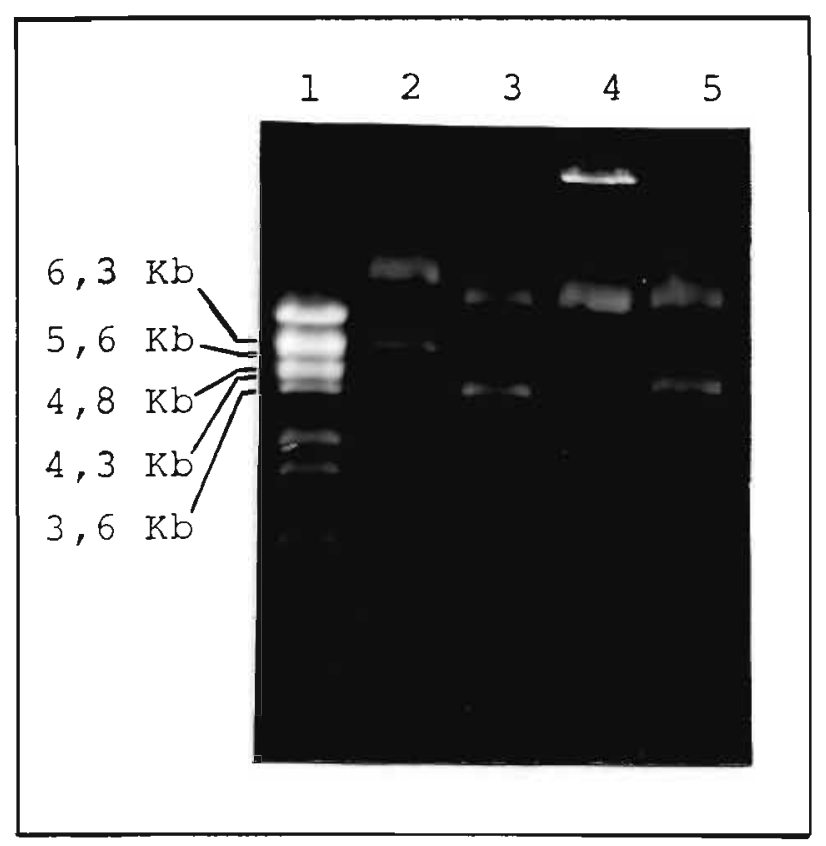

Fiqura 9. Eletroforese das preparacôs de vários DNAs plasmidiais (forma "supercoil"). Poco 1 - $\lambda$ BsteII; Poco 2 - pJJ11-1; Pofo 3 - DJC3-5; PO50 4 - DKKZ3J-2; POCO 5 - PET-3d. 
Observou-se que mesmo apos a purificacalo do DNA plasmidial em gradiente de cloreto de césio, nao ocorreu uma separacao completa entre as formas "supercoil" e com "nicks". Entretanto, comparando-se as bandas dos padrôes de PM com as bandas das amostras verificou-se que as formas "supercoil" estavam dentro do esperado.

Para a verificacăo da qualidade dos plasmideos, estes foram digeridos com HindII, para cuja enzima havia um sttio único de restriça em todas os plasmideos (Figura 10 ).

A preparaço de plasmideos na forma "supercoil" foi considerada adequada para uso posterior, uma vez que a eletroforese mostrou a presenca de uma banda proeminente.

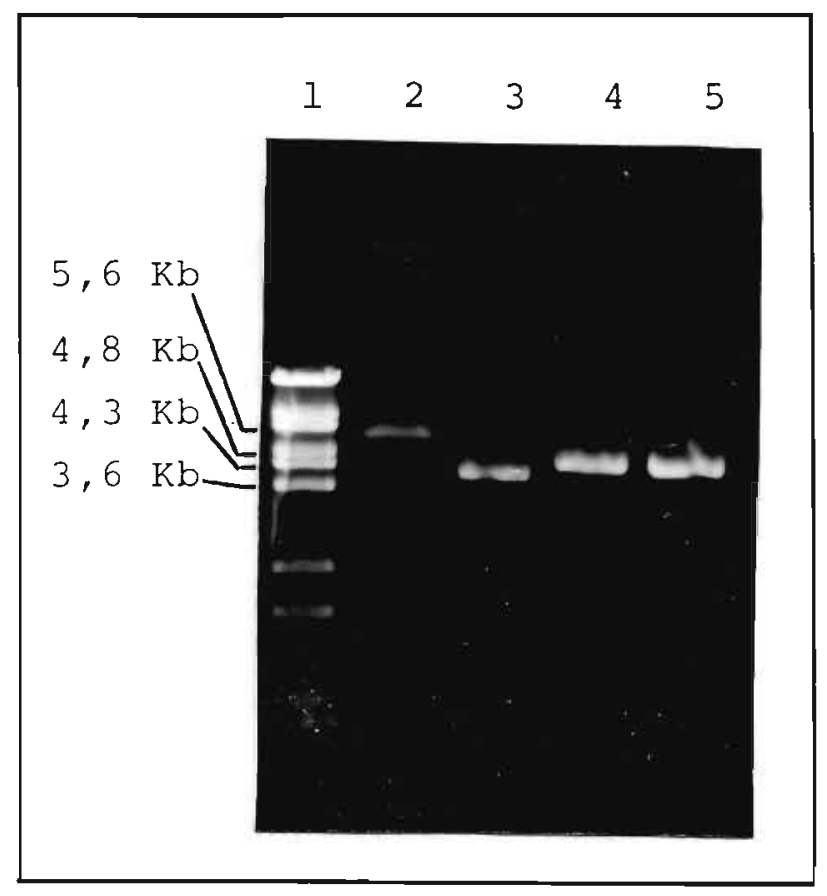

Fiqura 10. Eletroforese das preparaçaes de DNAs plasmidiais apos digestå com HindIII. Po६0 1 - $\lambda$ BsteII; Po६0 2 - pJJ11-1; Poto

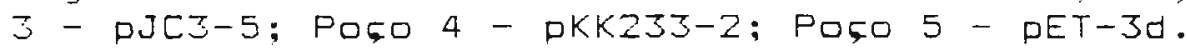




\subsection{Obtencáo dos plasmideos de expressao de FGF}

3.3.1. Qbtencaa de pJKA-1

(vetor pKK233-2 contendo o inserto para haFGF)

A estrategia de subclonagem de hafGF em pKK233-2 foi descrita no item 2.12.1. Sobre a mistura de reaço de ligacă, foram adicionados $200 \mathrm{ul}$ de suspensao bacteriana competente (E. Coli JM105). Os passos seguintes sao iguais aos descritos no ftem 2.J. Ds controles de eficiencia do antibiotico e de viabilidade bacteriana mostraram os resultados esperados. Na Tabela IV estão ilustrados os resultados desta transformacăo bacteriana.

Tabela IV. Clones transformados pela reacao de ligaço pKK233-2 + haFGF.

$\begin{array}{cc}\text { suspensao } & \text { No de clones transformantes } \\ 1 & 22\end{array}$

suspensao 1 - proveniente da reaço de transformacão bacteriana; suspensao 2 - suspenszo 1 aproximadamente vinte vezes concentrada. Observou-se um baixo numero de clones transformantes.

Da placa correspondente à suspensă 2 foram escolhidos 10 clones ao acaso para propagar, isolar e identificar os respectivos plasmideos. Para isso, foram feitas mini-preparacoes de plasmideos conforme descrito em "MATERIAIS E METODOS". Para verificar se houve insercao do fragmento de hafGF no plasmideo pKK233-2, digeriu-se separadamente uma amostra de plasmideos de todos as clones com a enzima de restriça HindIII; as amostras foram aplicadas em um gel horizontal $(11 \mathrm{~cm} \times 13,5 \mathrm{~cm})$ preparado a partir de agarose $1 \%$ dissolvida em 0,5 X TBE (Figura 11 ). 


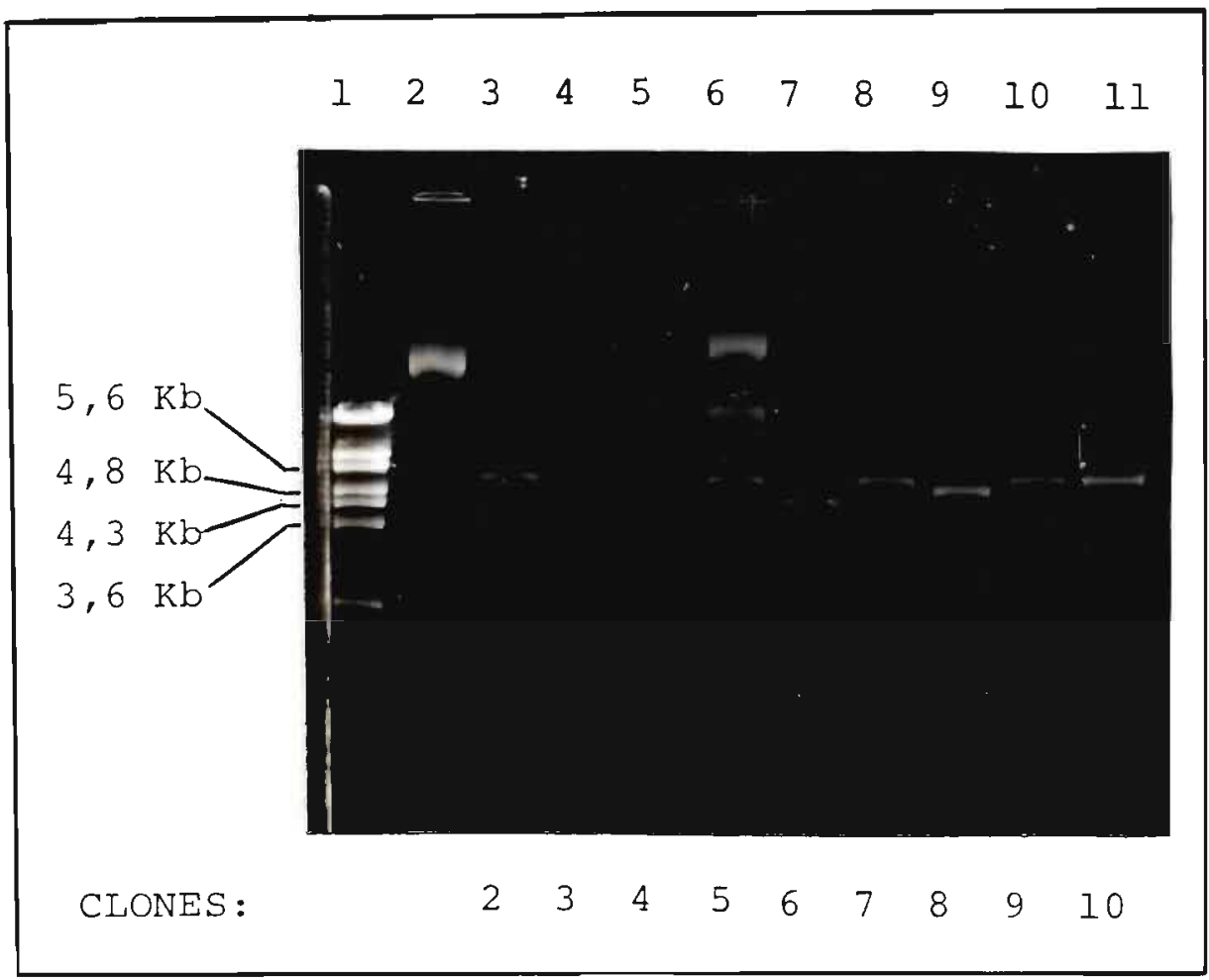

Fiqura 11. Eletroforese dos plasmideas dos clones isoladas da placa proveniente da suspensăo 2 (Tabela IV), digeridos com HindIII. POEO 1 - $\lambda$ BstEII; POE口 2 - pKK233-2 digerido con HindIII; Pocos 3 a 11 - indicados na figura. 
Aparentemente, os clones $2,4,5,7,9$ e 10 apresentam 0 fragmento de hafGF, uma vez que houve aumento de "peso molecular" dos plasmideos digeridos. D clone 1 ja havia sido digerido com HindII, e a eletroforese mostrou que nao houve insersao do fragmento (dado nao mostrado).

Para certificar se houve insercao, estes clones (ja digeridos com HindIII) foram digeridos com EcoRI. Esperava-se obter um fragmento com aproximadamente 750 bp apos eletroforese em gel de agarose, o que efetivamente ocorreu (Figura 12), confirmando a presenca do fragmento de hafGF. D plasmideo assim gerado foi designado pJKA-1. 


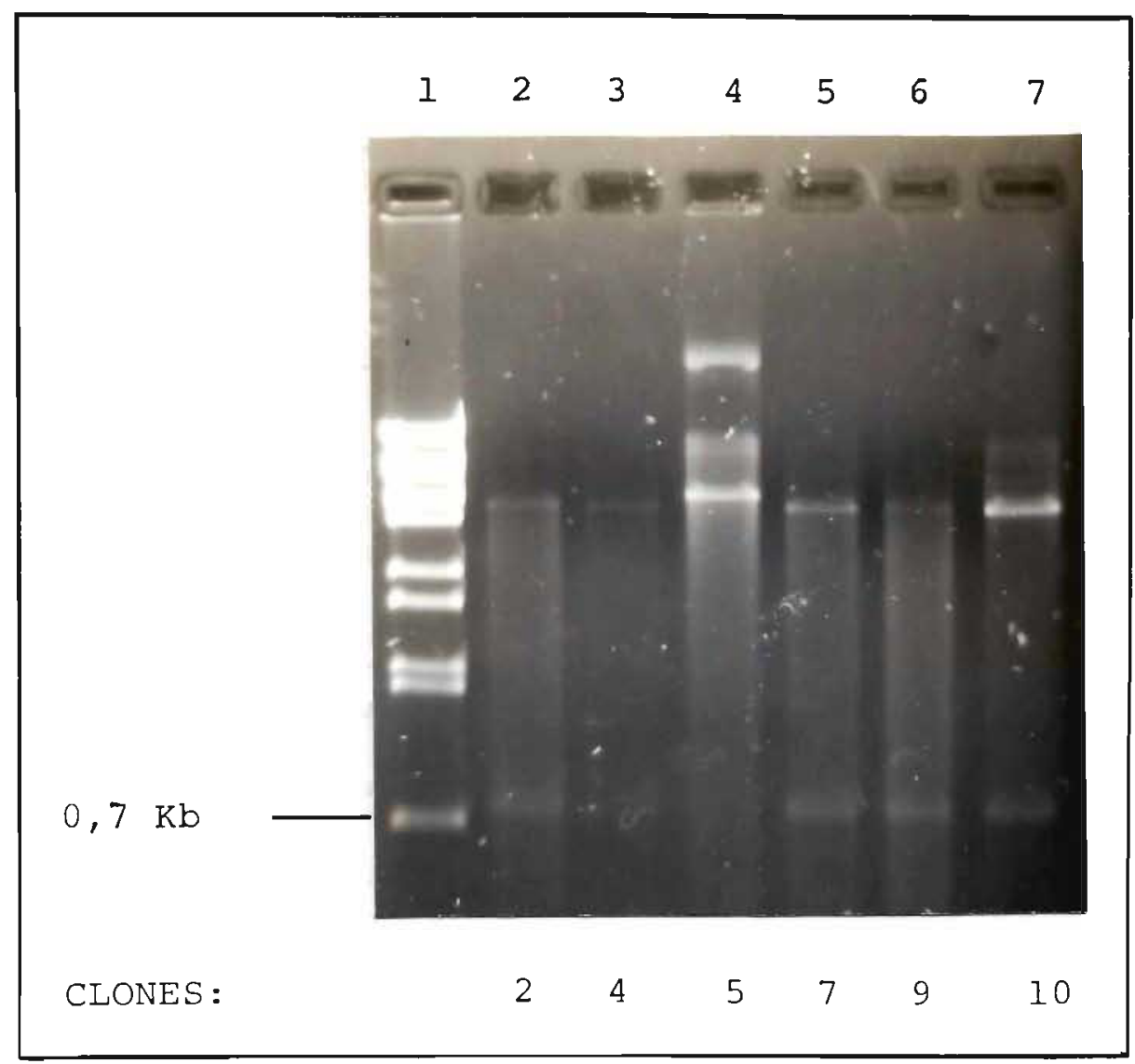

Fiqura 12. Eletroforese dos 6 clones digeridos com HindII e EcoRI que apresentaram aumento no "PM" após digestao com HindII. Poco 1 - $\lambda$ BsteII; Pocos 2 a 7 - indicados na figura. 
3.3.2. Qbtenczao de pJEA-1

(vetor PET-3d contendo o inserto para haFGF)

A estrategia de subclonagem de hafGF em pET-3d foi descrita no item 2.12.2. Sobre a mistura de reacao de ligacao, foram adicionados $200 \mathrm{ul}$ de suspensao bacteriana competente (E. coli HMS174). Os passos seguintes foram iguais aos descritos no item 2.3. Os resultados estao ilustrados na Tabela $\mathrm{V}$.

Tabela $V$. Resultados da transformacão de E. coli HMS174 com os plasmideos gerados da ligacao de pET-3d (NeoI-HindIII) + haFGF (NeoI-HindIII). Para a reacao de transformacão foram misturados $200 \mathrm{ul}$ de bacteria competente e $10 \mathrm{ul}$ do vetor (volume da reaça de ligase). No controle da reacao de transformaça (DET-3d) foram adicionados 2 ul do vetor. Para verificar o número de clones transformantes, 50 ul das suspensoes bacterianas foram plaqueadas sobre meio LBA (ampicilina 50 ug ml-1). A suspensao 1 provem da reaça de transformacao e a suspensao 2 corresponde a suspensao 1 aproximadamente vinte vezes concentrada. Foram feitos controles de viabilidade bacteriana e eficiencia do antibibtico, conforme descrito em 3.1 .

\begin{tabular}{|c|c|c|c|}
\hline & & No de clones & 15 formantes \\
\hline Amostra & Proporfao & Suspensã 1 & Suspensato 2 \\
\hline DET-3d + haFGF & $(1: 1)$ & 5 & 87 \\
\hline DET-3d + haFGF & $(1: 3)$ & 200 & 1000 \\
\hline PET-3d+ haFGF & $(1: 5)$ & 5 & 86 \\
\hline $\begin{array}{l}\text { pET-3d digerido e } \\
\text { incubado com ligase }\end{array}$ & - & 0 & 0 \\
\hline pET-3d digerido & - & 0 & 0 \\
\hline DET-3d & - & 23 & 250 \\
\hline
\end{tabular}

- numero de transformantes obtido após a reaça realizada na proporcao 1:5 foi semelhante a da 1:1. Este resultado pode ser devido a formacao de concatameros entre os fragmentos de hafGF. 
Dentre os clones transformantes foram escolinidos cinco ao acaso para verificar se realmente houve inserça do fragmento de haFGF. Foram feitas entao mini-preparacoles de plasmideos (conforme "MATERIAIS E METODOS") e estes foram digeridos com HindIII separadamente. Verificou-se que, aparentemente, todos os clones continham o inserto, uma vez que houve um ligeiro aumento de tamanio (PM) (haFGF $=468$ bp) en relacao ao pET-3d (NcoIHindIII) isolado (dados nao mostrados). Este vetor foi denominado pJEA-1.

3.3.3. Obtenczao de DJEB-1

(vetor pET-3d contendo o inserto de bbFGF)

- cDNA da porcao codificadora do gene nativo de bbFGF (fragmento NcoI-Sau3AI - Figura 3) foi inicialmente subclonado em PET-3d (digerido com NcoI-BamHI). Ao induzir os clones bacterianos contendo este vetor (pET-3d + bbFGF nativo), observou-se, apos eletroforese em gel de poliacrilamida-sDs das amostras, que nao houve a produça de proteinas em quantidades visiveis atraves de coloracăo com Coomassie-Blue, sugerindo baixa expressão (dados năo mostrados).

Resultados descritos na literatura sugeriam que modificaços da sequencia codificadora nativa possibilitariam a expressao da proteina em maior quantidade (Knoerzer \& cols., 1989). Estas modificacoes levavam em conta basicamente dois aspectos: (1) utilizaço de codons mais frequentes nos genes bacterianos altamente expressos e (2) necessidade de se evitar a formaczo de estruturas secundárias muito estaveis no mRNA, principalmente no inicio da mensagem. Seguindo esta abordagem, cerca de bo pares de bases da extremidade 5' da regiao codificadora do CDNA nativo foram substitufdas por oligonucleotideos sinteticos. Esta substituicăo permitiu diminuir o conteúdo de citosina mais guanosina que era de $77,9 \%$ para $57,6 \%$ (Figura 5). A nova sequencia da regiao codificadora do CDNA de bbFGF (bbFGFmodif.) 
foi inicialmente subclonada em puc19, para posterior sequenciamento, como descrito no item 2.12 .3 .

obtiveram-se cerca de 2.000 clones resistentes a ampicilina após transformacao de E. coli JM105 com a mistura de reacao (etapa 4 do item 2.12.3). Foram escolinidos 20 clones ao acaso para verificar se houve inserço do fragmento de bbfGFmodif. em pUC19. Os DNAs plasmidiais destes foram digeridos com EcoRI e Psti; após eletroforese em gel de agarose de 7 clones obtiveramse dois que contintiam o fragmento esperado de aproximadamente 1,3 Kb (Figuras $B$ e 13.a). Este plasmideo foi denominado pAuXB-1. 0 fragmento NCOI-SauBAI (etapa 6 do 1 tem 2.12.3) foi subclonado em PET-3d conforme descrito na etapa 9 do 1tem 2.12.3. A mistura da reacão de ilgacăo sofreu processo semelhante ao utilizado para obtencao de pJEA-1 (tabela V). Obtiveram-se cerca de 20 clones transformantes.

Como seria dificil visualizar o fragmento de CDNA de bbFGF inserido em PET-3d (existem 22 sitios de SauJAI em PBR322), os clones recombinantes foram selecionados atraves da expressao de proteinas. Para tanto, transformaram-se culturas de $E$. coli BL21(DE3) com os plasmideos destes clones que foram induzidos com IPTG (conforme item 2.19.2). Das 20 clones, apenas 3 expressaram - bbFGF (Clones 8,10 e 13 - Figura 16), concluindo-se dal que os vetores destes clones possuem a fragmento NcoI-SauBAI de 466 bp (item 2.12.3). Este vetor foi denominado pJEB-1 (Figura 13.b).

A porçao 5' da regiao codificadora de bbfGFmodif. foi sequenciada conforme descrito no item 2.13, confirmando-se o resultado esperado (Figura 5.6 ). 


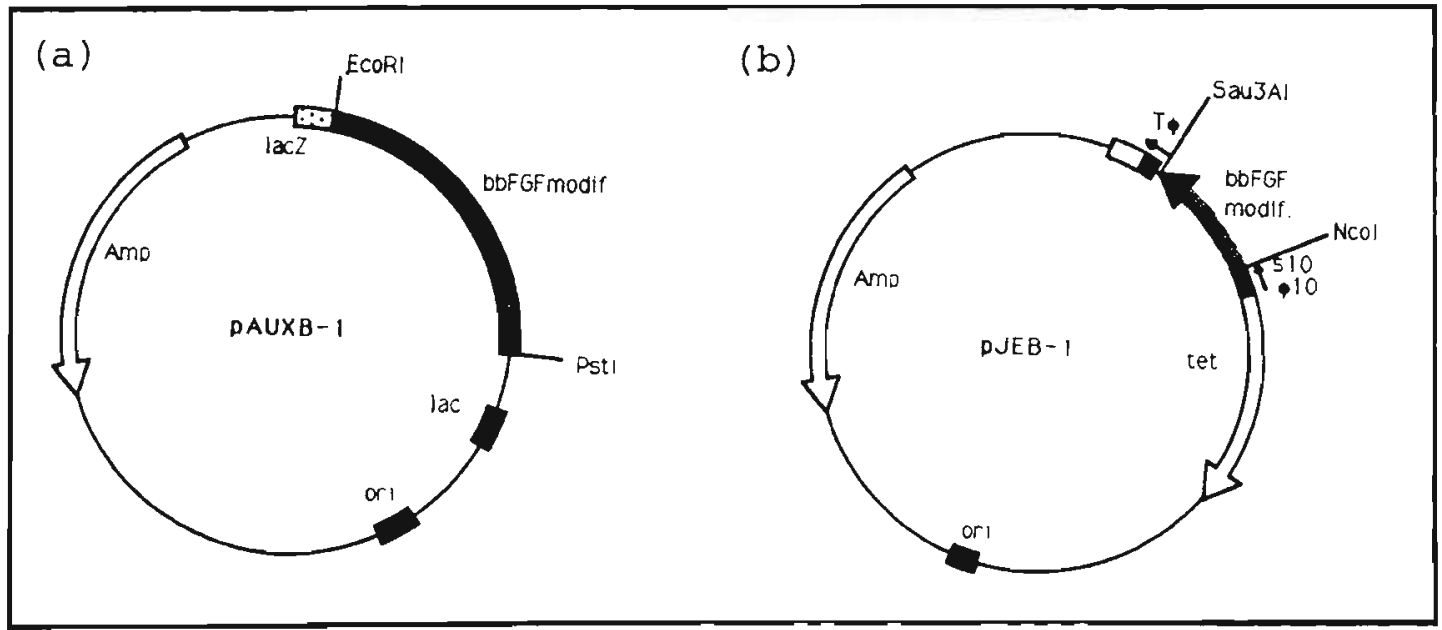

Fiqura 13. Plasmideos com bbFGFmodif. (a) pAUXB-1 - fragmento de DNA que contem a regiao codificadora do gene de bbFGFmodif. de aproximadamente $1,3 \mathrm{~kb}$ subcionado nos sitios Pst e EcoRI de pUC19; (b) pJEB-1 - formado através da ligafao da regiao codificadora (466 bp) do gene de bbFGFmodif. nos sitios de NcoI e BamHI de pET-3d. 


\subsection{Expressao das proteinas}

\subsubsection{Expressão em pequena escala de haFGF com pKK233-2}

Os clones de E. coli JM10s transformados com o plasmideo PJKA-1 (Figura 12) foram induzidos com IPTG conforme descrito no Item 2.19.1. Amostras de todos os clones induzidos, assim como dos controles nao induzidos, foram aplicadas em um gel de poliacrilamida-sDs. Após a eletroforese, as fracoes proteicas foram transferidas para uma membrana de nitrocelulose que foi corada com Ponceau $S$ ("MATERIAIS E METODOS") e fotografada (dados nå mostrados). A membrana foi entao incubada com o anti-soro anti-aFGF e a seguir com fosfatase alcalina, conforme descrito no Item 2.16. Os resultados ilustrados na Figura 14 mostram uma banda na regiáo esperada (cerca de $20 \mathrm{~K}$ ); houve o aparecimento de duas outras bandas em regibes de "PM" maior que provavelmente sao artefatos de técnica.

como a quantidade de hafGF produzida por este sistema foi visivel apenas atraves de reacáo com anticorpo, optou-se pelo sistema PET de expressao, com o objetivo de aumentar a producăo de proteinas. 


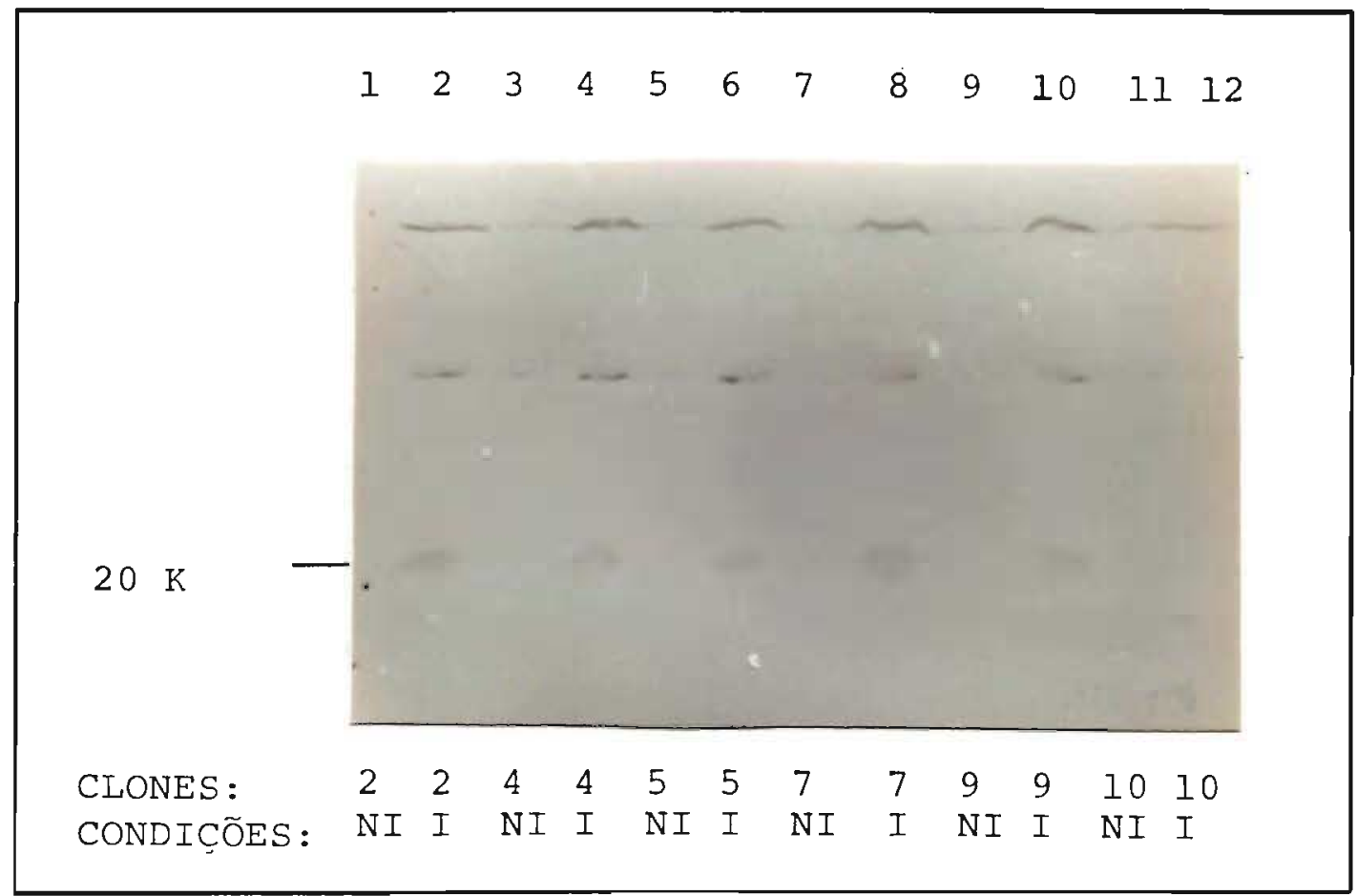

Figura 14. Western-blotting das fracâs proteicas das amostras induzidas (I) e nào induzidas (NI) dos clanes 2, 4, 5, 7, 9 e 10 de haFGF utilizando sistema pKK. As quantidades de proteínas das amostras nao induzidas adicinadas ao gel de poliacrilamida-sDs sào equivalentes às das amostras induzidas por IPTG. 


\subsubsection{Expressao de haFGF e bbFGF com PET-3d}

\subsubsection{Expressao em pequena escala}

Bacterias E. COIi BL21(DE3) transformadas separadamente com preparacoes de plasmideos (pJEA-1 - 5 clones e pJEB-1 - 3 clones) foram induzidas com IPTG (item 2.19.2) e as amostras geradas (item 2.20.1) foram analisadas atraves de eletroforese em gel de poliacrilamida-SDS (Figuras 15 e 16).

Nào se detectou a banda mais evidente na regiao de PM em torno de $18,4 \mathrm{~K}$ nos controles, ou seja, em bacterias nao transformadas (pocos 4 e 5 - Fig. 15.b e pocos 10 e 11 - Fig. 16) e em bacterias transformadas somente com $\square$ vetor sem inserto (pocos 6 e 7 - Fig. 15.b e pocos 12 e 13 - Fig. 16).

Isto e uma indicacaro de que as bandas mais intensas, detectadas nos clones induzidos, sejam de hafGF (Fig. 15) e bbfGF (Fig. 16).

Ds clones que apresentaram maior nivel de expressão de proteinas foram os de no= 2 e 5 (haFGF) e 0 de no 8 (bbFGF), provavelmente porque as bacterias estavam na concentracao mais adequada para expressao (Asocentre 0,8-0,9). Nao é clara no momento a razao pela qual o Clone 4 nao expressou hafgF (poco 8 Fig.15.a). 


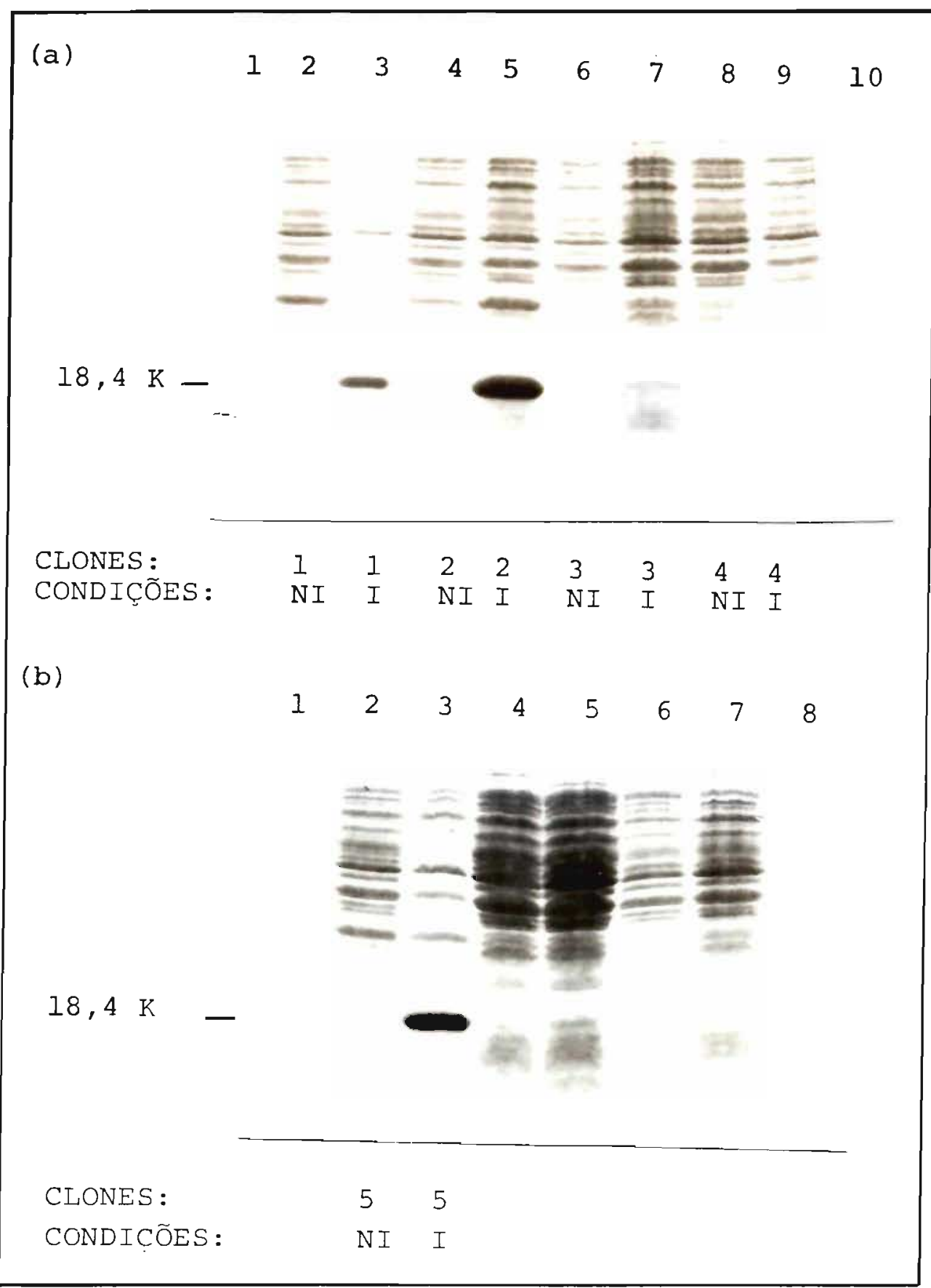

Fiqura 15: SDS-PAGE para verificaazo do nivel de expressao de hafGF utilizando sistema PET. (a) Pocos 1 e 10 - B-lactoglabulina ( $P M=18,4 \mathrm{KDa})$; Poৎas 2 a 9 - indicados na figura. (b) Pocos 1 e 8 - B-lactoglobulina; Pofos 2 e 3 - indicados na figura; Poco 4 E. EOIi BL21(DE3) NI; POCO 5 - E. EOIi BL21(DE3) I; POCO 6 - DETउd NI; POCO 7 - DET-3d I. 


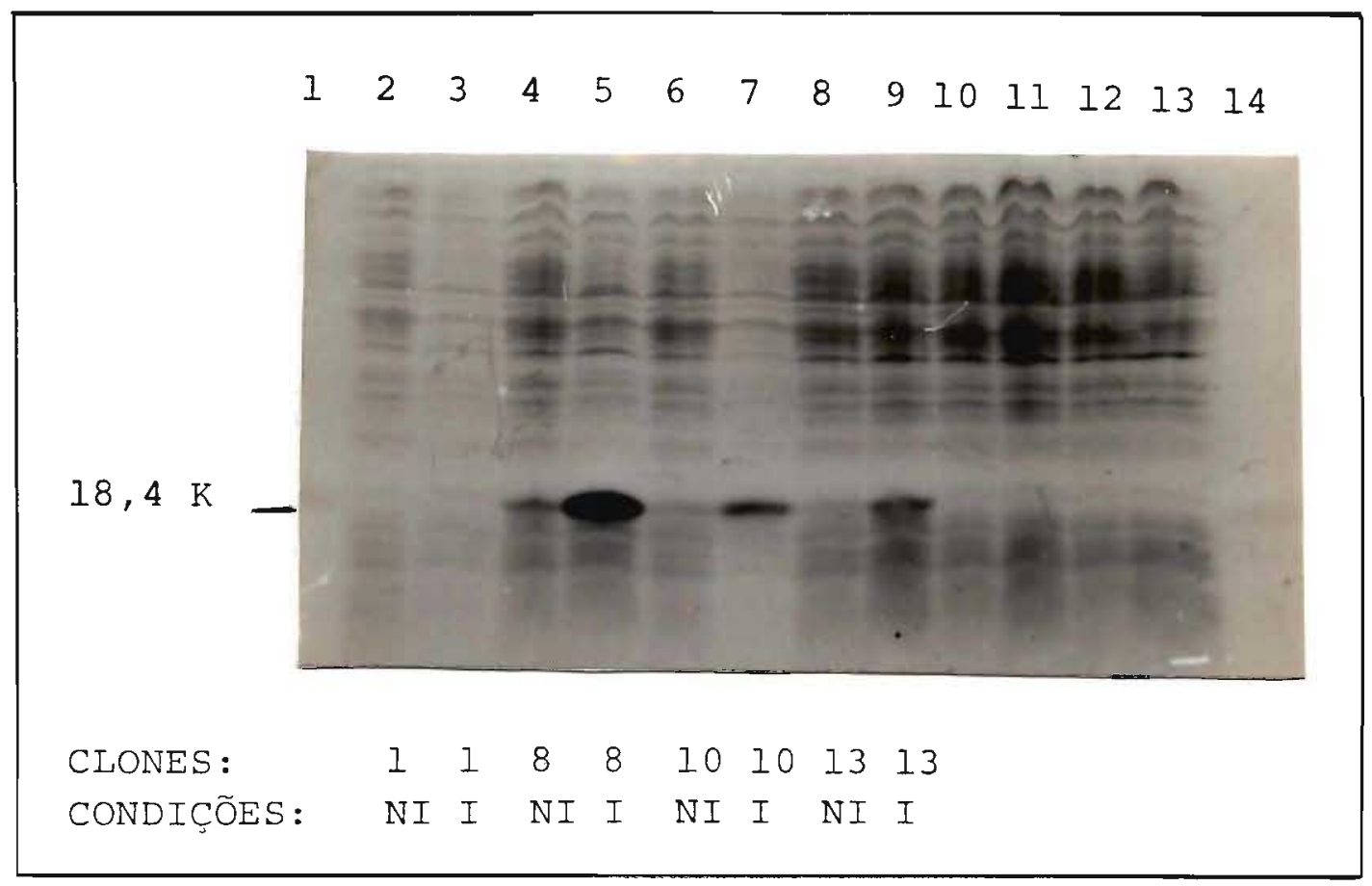

Fiqura 16. SDS-PAGE de 1 clone que nao expressou e de 3 que expressaram bbFGF utilizando sistema PET. Pocos 1 e 14 - Blactoglobulina; Pofos 2 a 9 - indicados na figura; Pofo 10 - E. COIi BL21(DES) NI; PO६O 11 - E. COIi BL21(DEJ) I; POङO 12 - pET3d NI; PO5O 13 - DET-3d I. 
3.4.2.2. Expressao em larqa escala

Os clones 2 (haFGF) e 8 (bDFGF) foram escolnidos para obtença de grande quantidade das proteinas. As preparacoes foram feitas conforme item 2.20.2. Assumindo-se que $A_{200}=1$

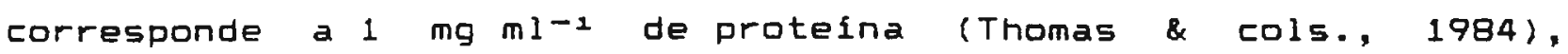
obteve-se cerca de $1500 \mathrm{mg}$ com E. coli BL21(DE3) + PJEA-1, e cerca de $1300 \mathrm{mg}$ com E. coli BL21(DEJ) + pJEB-1 de proteina total por litro de cultura induzida.

\subsection{Purificacao dos FGFs}

\subsubsection{Purificaçao de haFGF e Ensaio de Atividade Mitonenica das fracies cromatograficas}

\subsubsection{Eluicaa atraves de cradiente de $\mathrm{NaCl}$ por etapas}

A concentraçao de $\mathrm{NaCl}$ de todas as fraçoes eluidas da coluna por este procedimento foi estimada a partir da medida do indice de refracao. A quantidade de proteinas eluidas em cada fraço foi estimada a partir da Azoc. A maioria das proteinas é eluida com $0,5 \mathrm{M}$ de $\mathrm{NaCl}$, correspondendo ao material que nao adsorve ou adsorve fracamente na resina. Com 1,5 M de $\mathrm{NaCl}$, a medida de Azos aumenta $e$ decresce rapidamente formando um pico agudo. $\square$ material eluido com $2,5 \mathrm{M}$ nào foi incluido nas análises porque resultados anteriores (nao mostrados) indicaram que este nao apresentava atividade $e$ a quantidade de proteinas eluida era pequena. A finalidade desta eluicao era limpar a coluna das proteinas que tem grande afinidade por HS (Figura 17).

Para o estudo de atividade mitogenica, as fraças eluidas com NaCl 0,5 M foram agrupadas (grupo 1 - fraçoes 1-10; grupo 2 fracbes 11-30 e grupo 3 - fracbes 31-40). Como se esperava que o hafGF fosse eluido com $1,5 \mathrm{M}$ de $\mathrm{NaCl}$, todas as fracóes coletadas nesta etapa foram analisadas individualmente. As amostras foram testadas nas concentraços finais de 1,10 e $100 \mathrm{ng} \mathrm{ml}^{-1}$. A 
figura 17 mostra o perfil da atividade mitogenica das amostras na concentraça de $100 \mathrm{ng} \mathrm{ml}^{-1}$ (1 tem 2.23).

Verificou-se que $\circ$ pico de Azoo subia rapidamente quando a concentraço de $\mathrm{NaCl}$ aproximava-se de $1,5 \mathrm{M}$ e que a curva de atividade mitogenica estava deslocada para a direita. Isto era o esperado, uma vez que nesta regiăo o hafGF deve estar mais puro, - que pode ser comprovado analisando-se o padrao de bandas obtido em SDS-PAGE (Figura 18).

Uma banda mais evidente em torno de $18,4 \mathrm{~K}$ comecou a surgir a partir da fracao 41 (concentraça de $\mathrm{NaCl}$ - 0,70 M), tornandose mais intensa nas fraçes posteriores. 0 pico de atividade abrangeu as fraçoes 45-48. Nestas fraçoles, a banda de $18,4 \mathrm{~K}$ representou a maior parte do material corado com Coomassie-Blue. Nao temos dados no momento para dizer se a separacáo em duas bandas, que é mais evidente a partir da fracăo 46 , indica a presenca de formas microheterogeneas. 


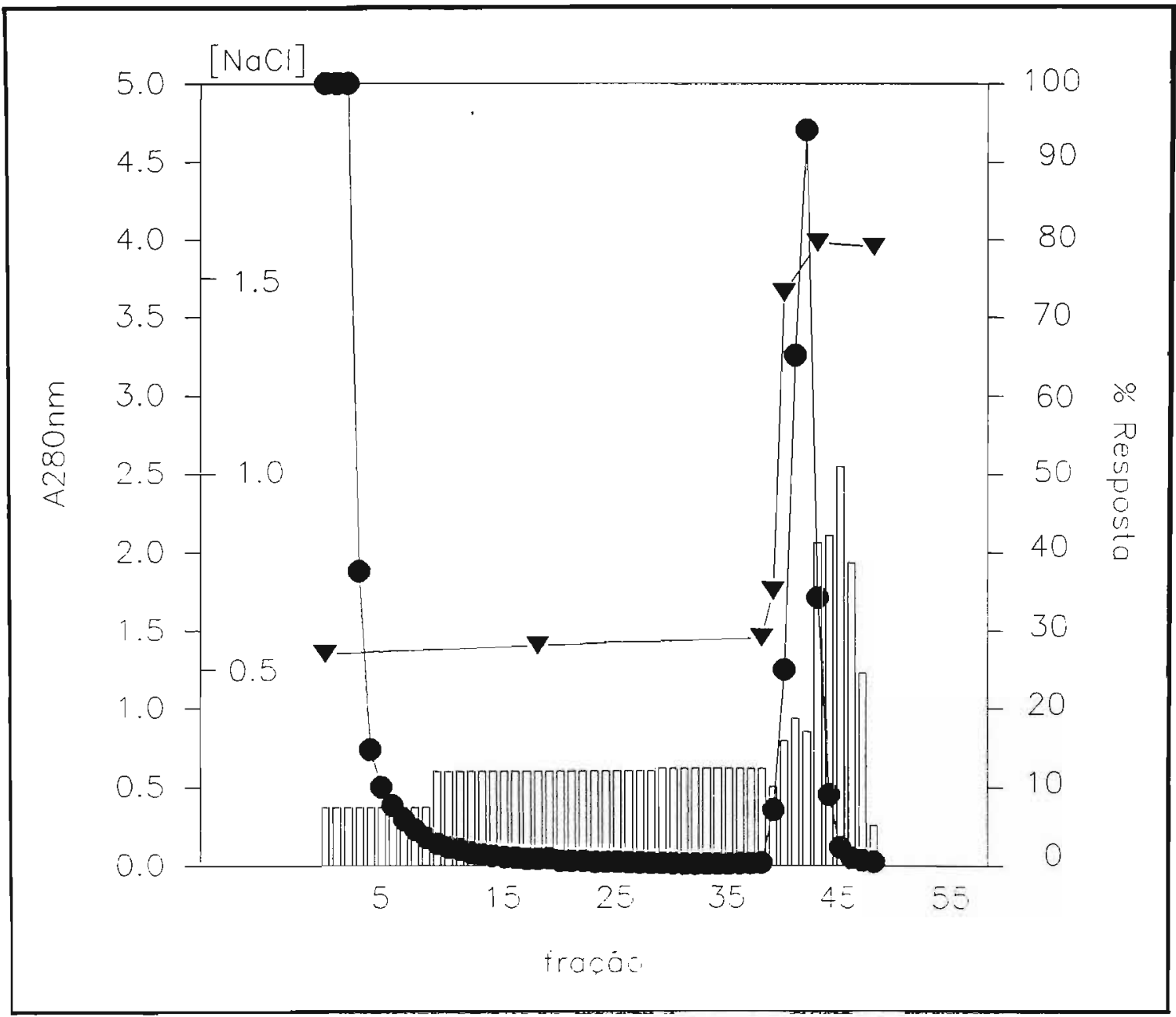

Fiqura 17. Eluicăo de hafGF atraves de gradiente por etapas de NaCl. Gráfico das medidas da Azes (O), da concentracăo de NaCl ( $\nabla$ ) e da atividade mitogenica (100 ng $\mathrm{ml}^{-1}$ ) das fracóses eluidas da coluna HS ( $\square$ ). 


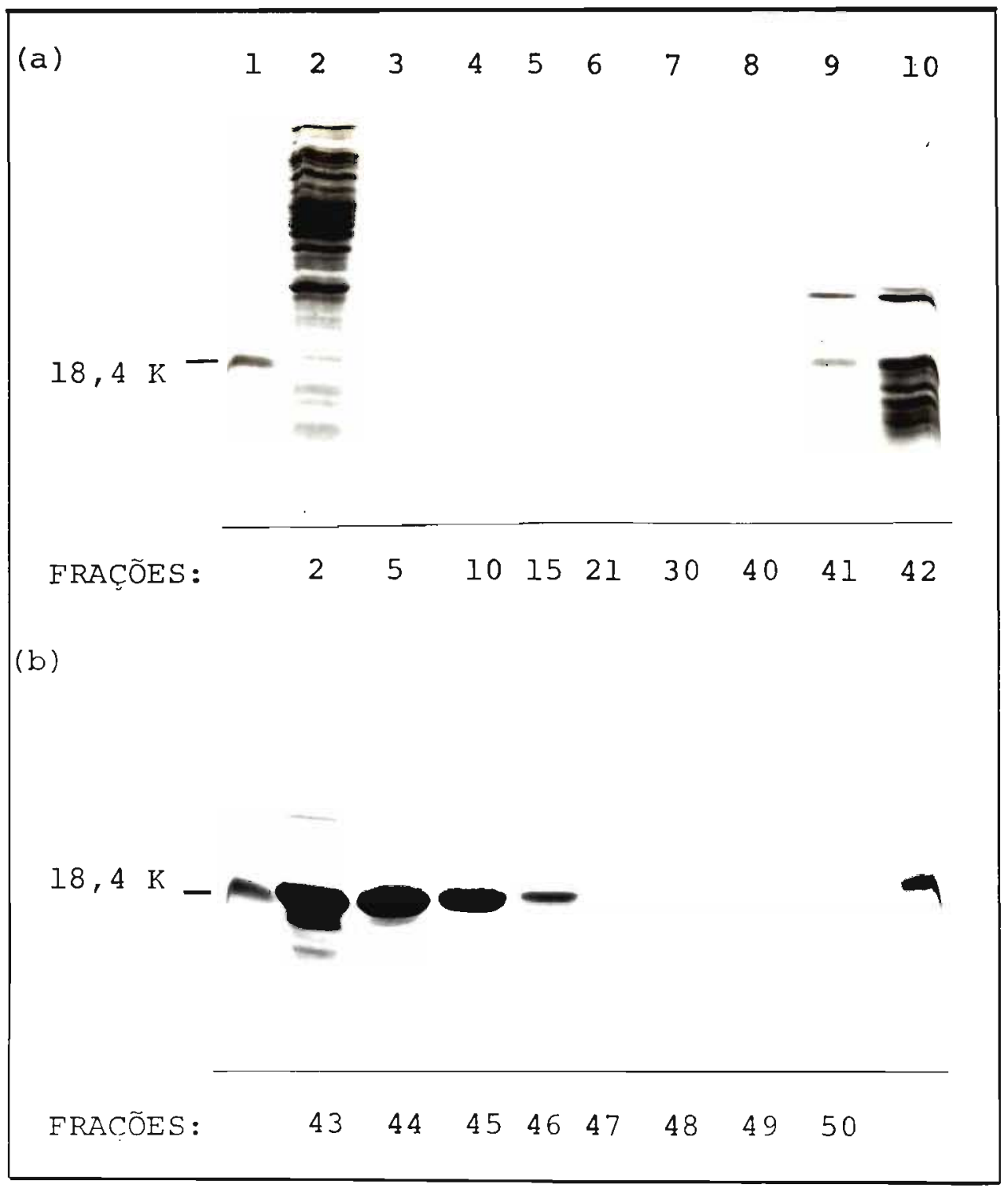

Fiqura 18. Purificafao de hafgF utilizando-se gradiente de NaCl por etapas. SDS-PAGE das principais fracaes eluidas da coluna de HS. A eluifáo foi realizada lavando-se a coluna com TF $10 \mathrm{mM} \mathrm{pH}$ 7,2 nas seguintes concentracóes de $\mathrm{NaCl}: 0,5 \mathrm{M}, 1,5 \mathrm{M}$ e 2,5M. As amostras foram diluidas $v: v$ cam tampao de amostra (seg. Laemmli) aplicando-se $10 \mathrm{ul}$ por amostra. (a) Poco 1 - B-lactoglobulina: Pocos $Z$ a 10 - indicados nafigura; (b) Pacas 1 e 10 - Blactoglobulina; Pocos 2 a 9 - indicados na figura. 


\subsubsection{Eluiczo atraves de gradiente linear de $\mathrm{NaCl}$}

Como mostra a Figura 18, năo ocorreu uma boa separacăo do hafGF eluindo-o da coluna de $H S$ atraves do aumento da concentraça de NaCl por etapas. No sentido de melhorar a purificacăo desta proteina, o material retido na coluna foi eluido atraves de gradiente linear de NaCl conforme 1 tem 2.21. A concentraçao de $\mathrm{NaCl}$ e a quantidade de proteina em cada fraçăo eluida da coluna, por este procedimento, foram estimadas conforme item 3.5.1.1 e as resultados estao ilustrados na Figura 19.

Para $\circ$ estudo de atividade mitogenica (item 2.22) do material eluido, todas as fraçes do gradiente de NaCl foram testadas na concentraço final de $200 \mathrm{ng} \mathrm{ml}^{-1}$ (item 2.23) (Figura 19).

Verificou-se que nas fracoes do gradiente de $\mathrm{NaCl}:(1)$ a Azec, aumentava com a concentraça salina formando um pico largo ao redor de 1,0-1,2 M, quando comefava a diminuir até tornar-se desprezivel ao redor de $1,5 \mathrm{M}$; e (2) a atividade mitogenica era semelhante em todas as fraçoes. Este resultado era esperado, uma vez que o hafGF era eluido com um grau de pureza da ordem de $95 \%$ ou mais já no inicio do gradiente, exibindo uma única banda visivel por coloracă com Coomassie-Blue apos eletroforese em gel de poliacrilamida-SDS (Figura 20). Qualquer uma destas fracaes pode ser utilizada para ensaios posteriores.

As concentracóes de proteinas de todas as fracoles do gradiente de NaCl foram medidas conforme item 2.23 e estimou-se um rendimento de hafGF na ordem de $40 \mathrm{mg}$ por litra de cultura bacteriana induzida, na fracăo solúvel.

Para um estudo mais detalhado da atividade mitogenica do haFGF recombinante, curvas de dose-resposta foram realizadas, conforme item 2.22, da proteina sozinha e na presenca de heparina.

O hafGF sozinho era ativo na ordem de ng $\mathrm{ml}^{-1}$, com DEsox (dose de estimulaczo correspondente a $50 \%$ de resposta) igual a $150 \mathrm{ng} \mathrm{ml}^{-1}$ (Figura 21). 
Para estabelecer a concentracăo potenciadora ideal de heparina, foram feitos ensaios de atividade mitogenica do hafGF ( 5 e $10 \mathrm{ng} \mathrm{ml}^{-1}$ ) na presenca de varias concentraçoes do glicosoaminoglicano (GAG). Verificou-se que em baixas concentraços năo ocorria potenciaçăo da atividade do hafGF. Resposta celular maxima foi obtida em torno de 5-10 ug $\mathrm{ml}^{-1}$ do GAG; concentracoles superiores levaram a uma inibicáo da sintese de DNA (dados nao mostrados).

A Figura 21 mostra que a curva da atividade do hafGF na presenca de 0,1 ug $\mathrm{ml}^{-1}$ de heparina é semelhante a do fator na sua ausencia ( $D E_{s a}=150 \mathrm{ng} \mathrm{ml}^{-1}$ ), enquanto na presenca de $10 \mathrm{ug}$ $m^{-1}$ a atividade e potenciada cerca de 5.000 vezes (DEso\%=0,03 ng $\left(1^{-1}\right)$.

Verificou-se que a DEso\% da proteina, a resposta maxima da célula e a potenciacáo por heparina variam com as condicóes do ensaio e/ou do hafGF. Quanto maior o tempo da celula em cultura, menor a resposta perante o fator. Congelamentos e descongenlamentos da proteina levaram a uma desnaturacao que acarretou perda de atividade. Adiczo de heparina reverteu parcialmente este efeito (dados nao mostrados). Verificou-se também que em altas concentracóes de hafGF ocorreu inibicao da sintese de DNA, tanto isoladamente, como na presenca de heparina, efeito este que ainda não foi esclarecido. 


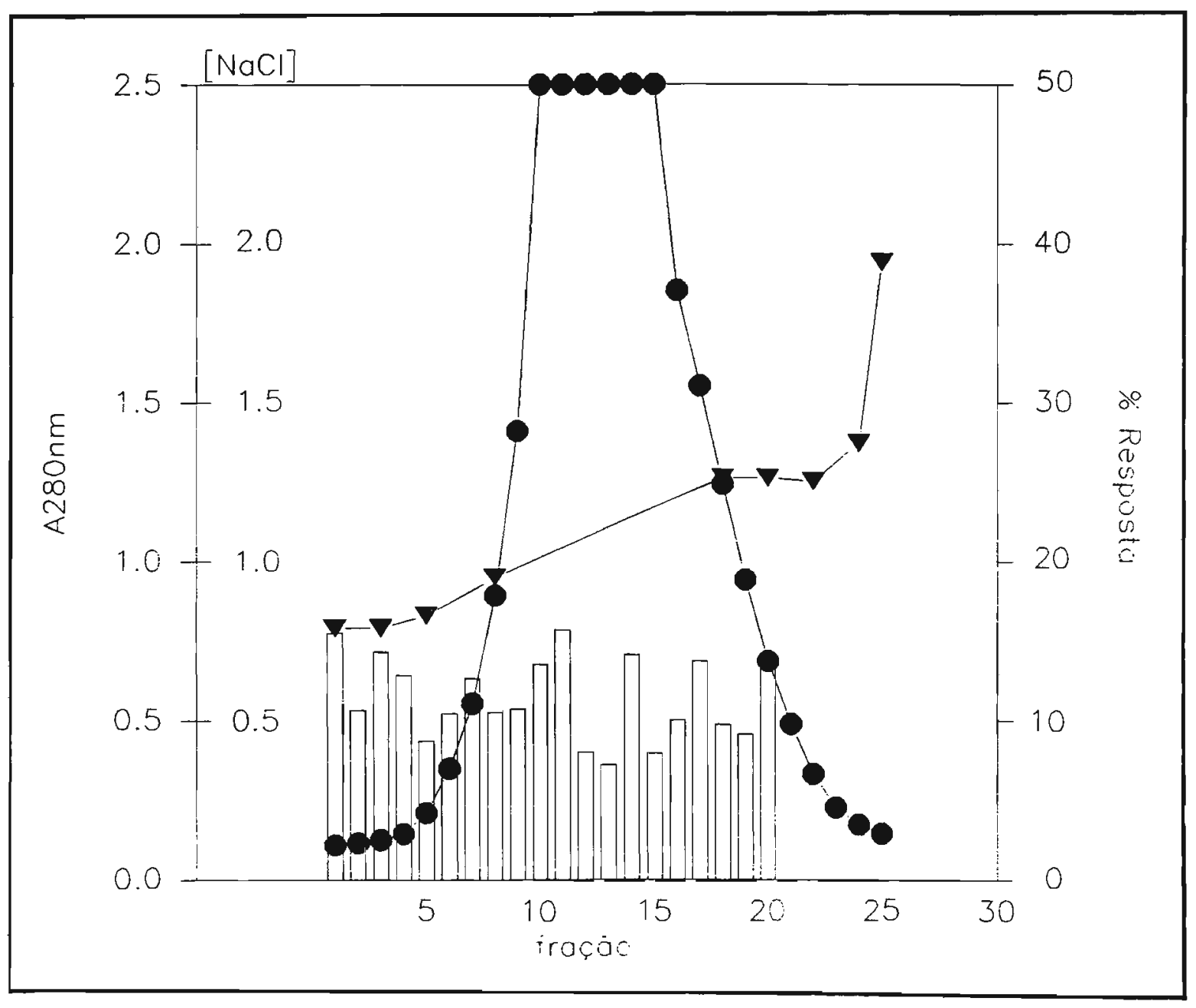

Fiqura 19. Eluiço de hafGF atraves de gradiente linear de $\mathrm{NaCl}$. Gráfico das medidas de $A=00$ (O), da concentracáo de $\mathrm{Nacl}(\boldsymbol{\nabla})$ e da atividade mitogenica (200 ng $\mathrm{ml}^{-1}$ ) das fracoes eluidas da coluna de HS ( $\mathrm{D}$ ). 


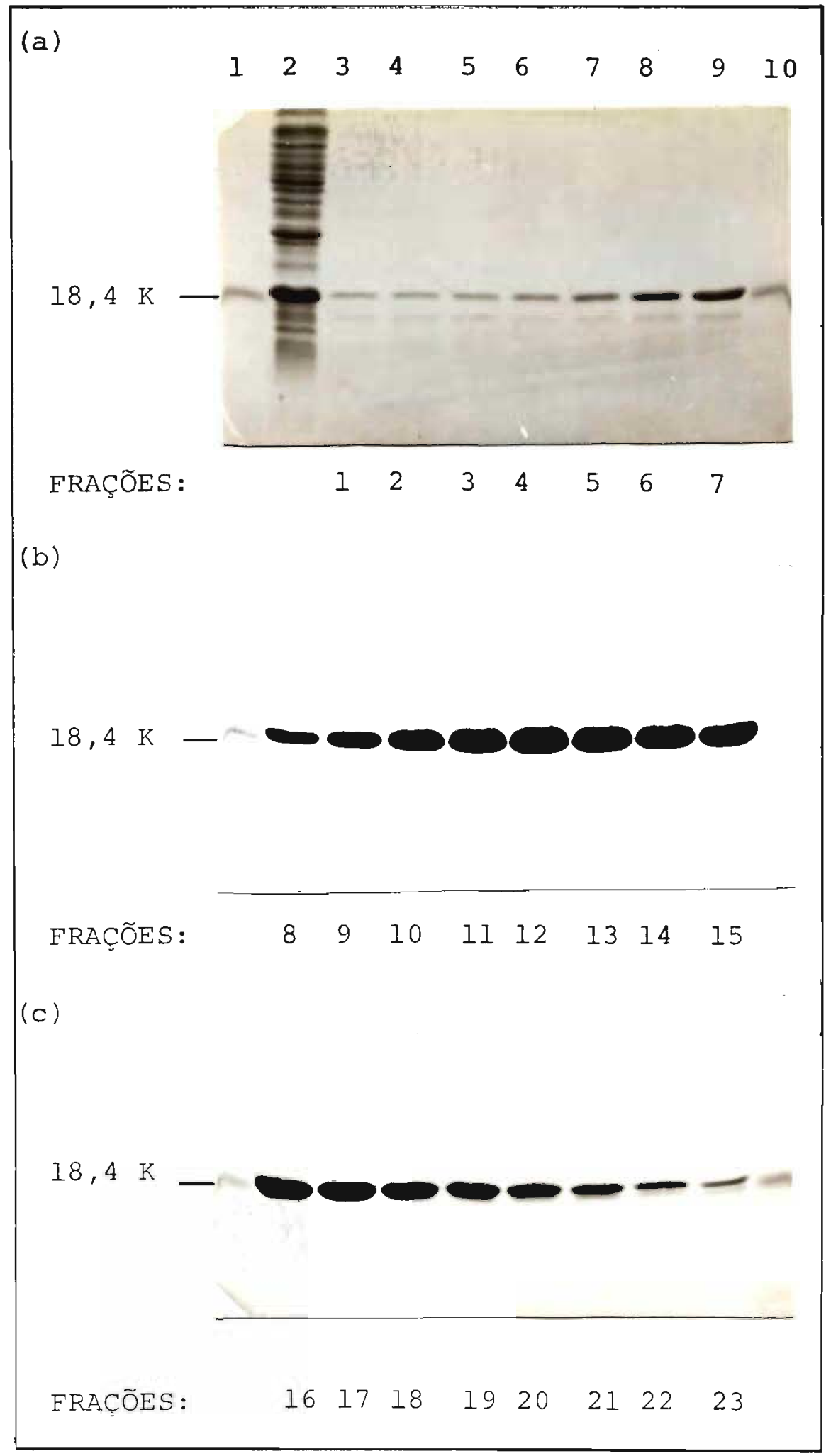

Fiqura 20. Purificafao de hafGF utilizanda-se gradiente linear de NaCl. SDS-PAGE das fraçes eluidas da coluna de HS. O material foi eluido da coluna com TF mas seguintes concentracäes de Naci: $0,5 \mathrm{M}, 0,7 \mathrm{M}$, gradiente 0,7 M - 1,8 M, 1,8 M e 2,5 M. As amostras foram preparadas conforme legenda da Figura 18. (a) Pocos 1 e 10 - B-lactoglobulina; Pofo 2 - extrato crú; Pocos 3 a 9 - indicados na figura. (b) Pofos 1 e 10 - B-lactoglobulina; Pocos 2 a 9 indicados na figura. (c) Pocos 1 e 10 - B-lactoglobulina; Pocos 2 a 9 - indicados na figura. 


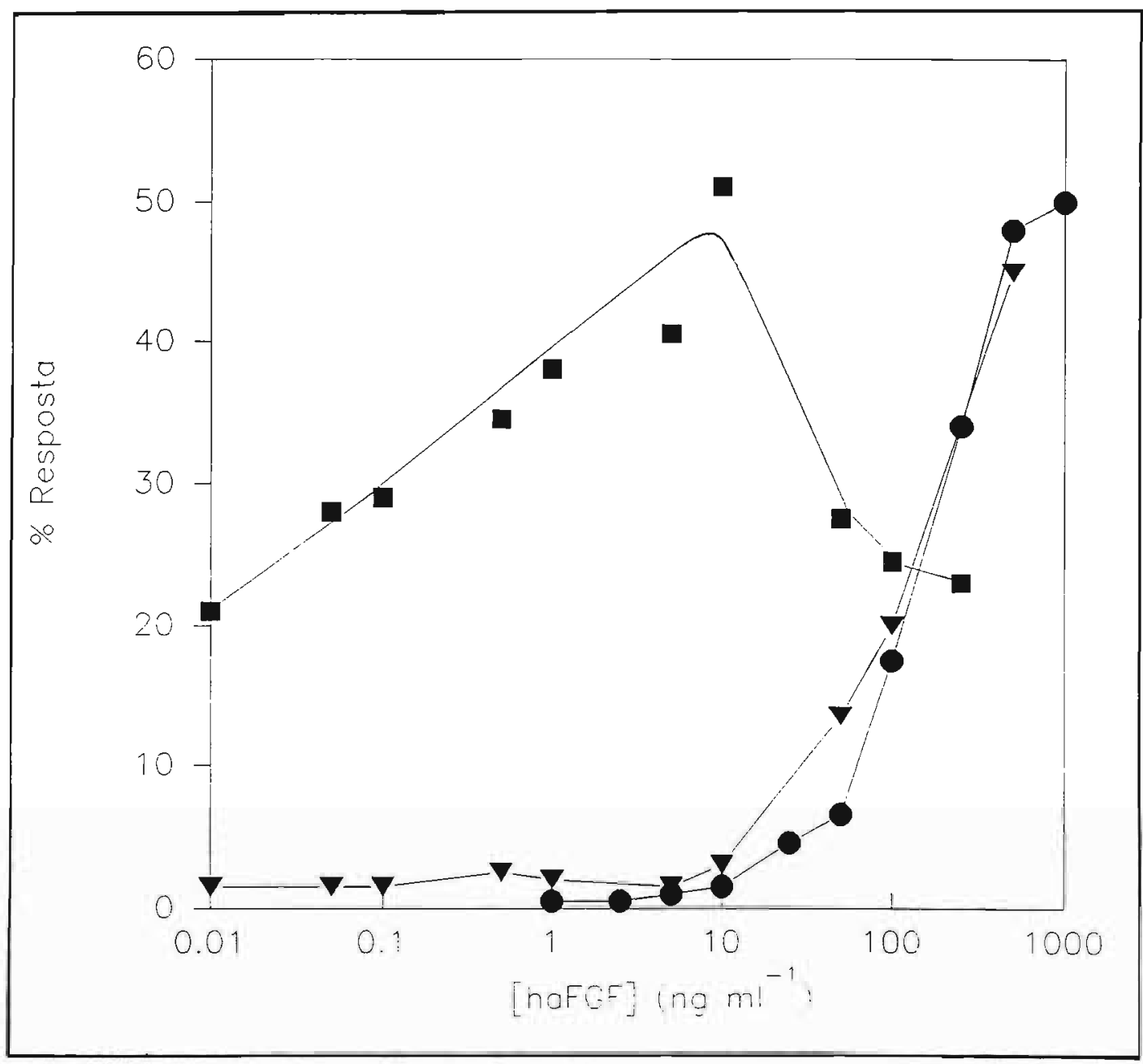

Fiqura 21. Curva de dose-resposta do hafGF e efeito de duas concentraçes da heparina na atividade do hafGF. (O) hafgF sozinho, ( $\boldsymbol{\nabla}$ ) hafGF na presenca de 0,1 ug $\mathrm{ml}^{-1}$ de heparina e ( $\mathbf{a}$ )

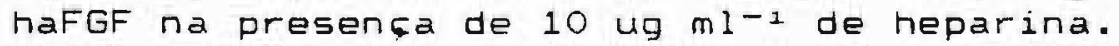




\subsubsection{Purificacao de bbFGF e Ensaio de Atividade Mitonenica das fracbes cromatograficas}

Como mostra a Figura 20, o hafGF foi eluido da coluna de HS com um grau de pureza da ordem de $95 \%$. Optou-se entzo por purificar o bbFGF por este metodo, conforme descrito em 2.21.

As estimativas das concentraçoes de $\mathrm{NaCl} e$ de proteina em cada fracáo eluida da coluna foram realizadas conforme item 3.5.1.1. Os resultados estao mostrados na figura 22.

Para 0 estudo da atividade mitogenica das fracobes cromatográficas, as de números 4-12 do gradiente de NaCl foram testadas nas concentraçes finais de 100 e $500 \mathrm{pg} \mathrm{m} \mathrm{m}^{-1}$. A Figura 22 mostra os resultados na concentrafăo 500 pg $\mathrm{ml}^{-1}$.

Verificou-se que o bbFGF comesou a ser elusdo com aproximadamente $1,2 \mathrm{M}$ de $\mathrm{NaCl}$ (fracăo 4), formando um pico agudo com um pequeno arraste deslocado para a direita.

A Figura 23 mostra que esta proteina el eluida da coluna de HS com uma pureza da ordem de $95 \%$ ou maior. 


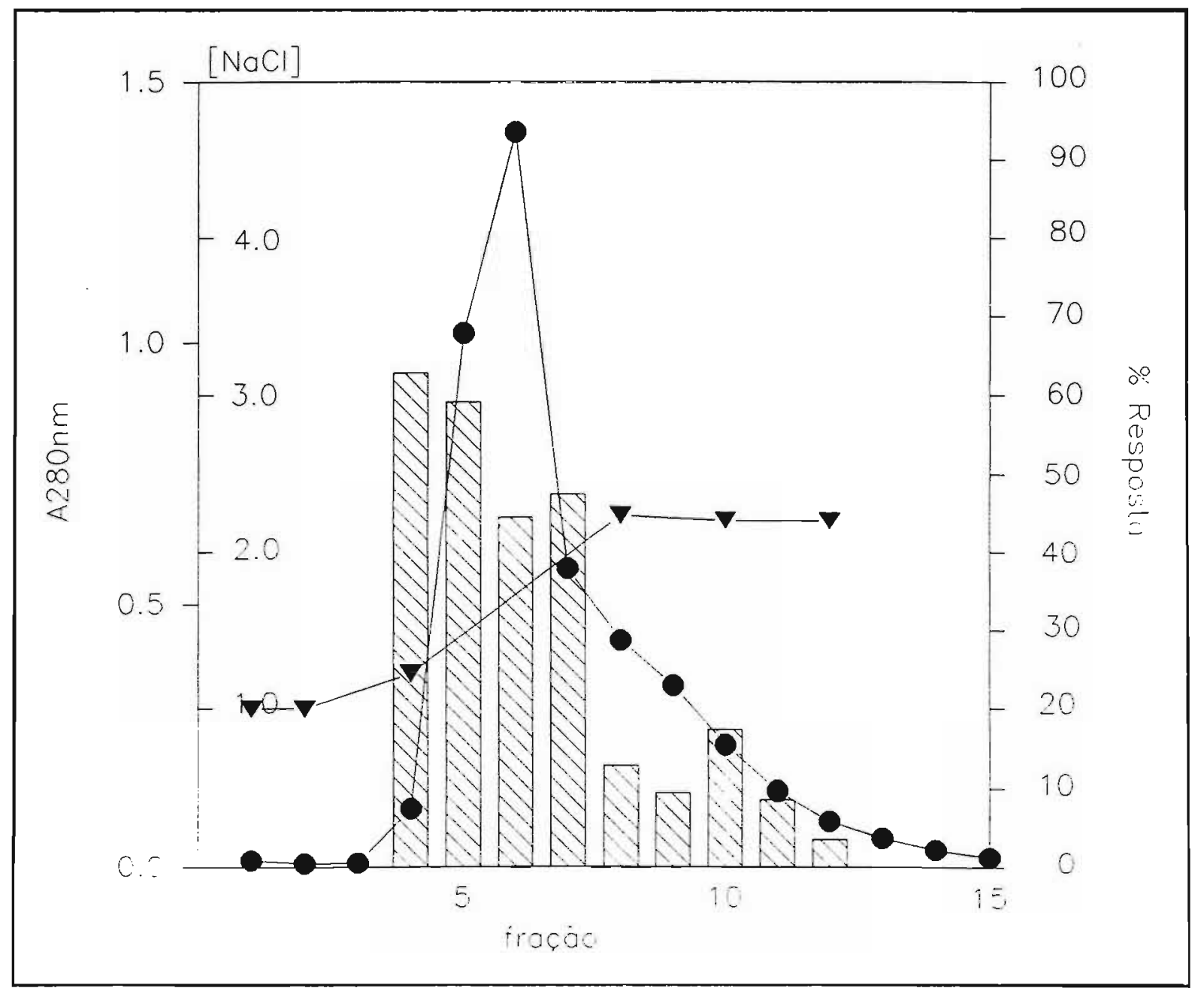

Fiqura 22. Eluigao de bbFGF atraves de gradiente linear de NaCl. Grafico das medidas da Azos (O), da concentracăo de $\mathrm{NaCl}$ ( $\mathbf{V}$ ) e da atividade mitogenica (500 $\mathrm{pg} \mathrm{m}^{-1}$ ) das fracoes 4-12 do gradiente ( $\mathbf{Q})$. 
$\begin{array}{llllllllll}1 & 2 & 3 & 4 & 5 & 6 & 7 & 8 & 9 & 10\end{array}$

$18,4 \mathrm{~K}-$

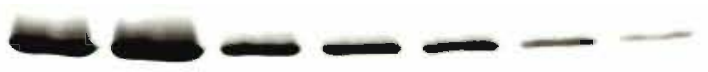

FRACÕES : $\quad \begin{array}{llllllllll} & 4 & 5 & 6 & 7 & 8 & 9 & 10 & 11 & 12\end{array}$

Fiqura 23. Purificacao de bbFGF através de gradiente linear de NaCl. SDS-PAGE das fracbes eluidas da coluna de HS. O material foi elufdo da coluna com $T F$ $10 \mathrm{mM}$ pH 7,2 nas seguintes concentraçes de $\mathrm{NaCl}$ : 0,6 M, 1, O M, gradiente linear 1,0 - 2,5 M e $2.5 \mathrm{M}$. As amostras foram preparadas conforme legenda da Figura 18. Poco 1 - B-lactoglobulina; Pofos 2 a 10 - indicados na figura. 
- gel de poliacrilamida-SDS apos eletroforese das fraçes do gradiente de $\mathrm{NaCl}$ corado com Coomassie-Blue mostrou que o bbFG foi eluido da coluna de HS com uma pureza da ordem de $95 \%$ ou mais (Figura 23). Nota-se nesta figura um arraste acima da banda principal, para o qual ainda nao se tem uma explicaça. Mediu-se a concentraço de proteinas destas fracbes conforme item 2.23 , estimando-se um rendimento de bbFGF na ordem de $10 \mathrm{mg}$ por litro de cultura bacteriana induzida, na fracăo solúvel.

Todos os ensaios posteriores foram realizados com proteinas com este grau de pureza.

Ensaios de dose-resposta do bbfGF foram realizados e verificou-se que este é ativo na faixa de pg $\mathrm{ml}^{-1}$ e que a heparina nad apresenta efeito significante sobre o fator (dados năo mostradosi.

\subsection{Análises da composicão e sequenciamento de aminoacidos dos FGFs produzidos}

Estas analises foram realizadas pelo Dr. Angelo Geraldo Gambarini.

A composicao de aminoacidos das duas proteinas foi determinada após hidrolise com HCl em fase gasosa, separacá dos aminoácidos em coluna de troca ionica e pós-derivatizacáo com nintidrina (Spackman \& cols., 1958). Estas analises foram efetuadas em um analisador de aminoacidos modelo SYSTEM 6300 Beckman.

As sequencias N-terminais do nafGF $e$ do buFGF foram determinadas num sequenciador automático apos pré-derivatizacăo com PITC (Hunkapiller \& cols., 1986) das proteinas adicionadas ao sequenciador (modelo 473A-01 - Applied Biosystems).

Aparentemente há apenas uma forma de hafGF correspondendo a proteina autentica de 154 aminokcidos. Duas formas de bufGF recombinantes foram encontradas, uma correspondendo à proteina autentica de 154 aminoacidos (cerca de $75 \%$ ) e outra contendo 153 
(cerca de $25 \%$ ) sendo que os dois primeiros residuos (Met-Ala) foram removidos (Figura 1 ). 


\section{DISCUSSAO}

- objetivo deste trabaliho foi o desenvolvimento de sistemas adequados para a produça de dois componentes da familia dos FGFs: o FGF ácido humano (pI 5-6) e o FGF básico bovino (pI 910). Esta proposifăo foi subdividida em tres fases: (1) construfăo dos vetores de expressão contendo as sequencias genicas adequadas; (2) producao de FGF em escala laboratorial; e (3) purificacăo e caracterizacăo quimica e biologica dos produtos obtidos.

Inicialmente optamos por expressar as proteinas em E. 민 usando o vetor pKK233-2, no qual as sequencias genicas ficam sob controle do promotor tre (Amann \& Brosius, 1985). Apesar de alguns dados da literatura indicarem alta expressao dos fGFs neste sistema (Jaye \& cols., 1997; Linemeyer \& cols., 1987), conseguimos expressar o haFGF em quantidades detectaveis somente por anticorpos (Figura 14). Modificacoes das condicoes de cultura ou de induçao (resultados năo mostrados) năo mel horaram o nivel de expressão.

No sentido de aumentar a producăo dos FGFs, optamos por um sistema que utiliza a T7 RNA polimerase para a expressao seletiva de DNAs (Studier \& cols., 1990), uma vez que esta enzima é cerca de cinco vezes mais ativa do que a de E. coli, e dados de Iiteratura mostravam altos niveis de expressao de bFGF (Squires \& cols., 1988) e afGF humanos (Watanabe \& cols., 1990) neste sistema. Embora maior expressao de hafGF tenna sido obtida, o mesmo nao aconteceu para o bbFGF. Este resultado parece indicar que neste último caso o problema näo estaria relacionado com a menor disponibilidade de mRNA especifico.

Os trabalhos de producăo de afGF em E. coli publicados na Iiteratura mostram que os autores utilizaram cDNAs totalmente sinteticos (Linemeyer \& cols., 1987; Barr \& cols., 1988; Watanabe \& cols., 1990; ke \& cols., 1990) ou com o inicio da sequencia codificadora trocada por oligonucleotideos sinteticos (Jaye \& cols., 1987), correspondentes as formas truncadas da proteina. 
maior nivel de expressao foi de $50 \mathrm{mg}$ por litro de cultura induzida (Ke \& cols., 1990), da proteina na forma [16-155] (ver Figura 2). Neste trabalho, conseguimos expressar cerca de $40 \mathrm{mg}$ por litro de cultura, da proteina autentica [2-155] (ver figura 2), com CDNA nativo pouco modificado (ver página 13).

Quanto ao bFGF, os trabalhos publicados na literatura mostram a utilizaçăo de: (1) cDNAs sintéticos correspondentes as formas truncadas da proteina (Barr \& cols., 1988; Fox \& cols., 1988; Knoerzer \& cols., 1989); (2) cDNA correspondente a proteina de 154 aminoacidos onde $\circ$ inflio da sequencia foi substitufda por oligonucleotideos sintéticos (Thompson \& cols., 1991); (3) CDNA nativo correspondente a forma truncada (Iwane \& cols., 1987); e (4) cDNA nativo acrescido de tres codons antes do ATG inicial do hbFGF, formando uma "proteina de fusao" contendo 157 aminoacidos, (Squires \& cols., 1988). Destes, Squires \& cols. (1988) e Thompson \& cols. (1991) abtiveram os maiores niveis de expressao (cerca de $40 \mathrm{mg}$ por litro de cultura induzida). Neste trabalho, utilizando cDNA nativo, năo conseguimos expressar o bbFGF em quantidades visiveis atraves de coloracao por Coomassie-Blue (dados nao mostrados). Modificamos entao a sequencia codificadora nativa de modo que: (1) o número de codons que sao mais frequentes nos genes bacterianos altamente expressos aumentasse, e (2) a formacão de estrutura secundaria muito estável no mRNA, principalmente mo inicio da mensagem diminuisse. Para isso, cerca de $b 0$ pares de bases da extremidade 5' da regiao codificadora do EDNA de bbFGF foram substituidas por oligonucleotideos sintéticos, diminuindo o conteúdo de citosina mais guanosina de $77,9 \%$ para $57,6 \%$ Com esta nova construcao (Figuras 5.b e 13.b), a produça de bDFGF foi da ordem de $10 \mathrm{mg}$ por litro de cultura bacteriana induzida, na fracao soluvel (Figura 16). Nao temos evidencias diretas de que com este eDNA modificado tenha diminuido a formacao de estrutura secundaria estável do mRNA, amentado o nivel de mRNA especifico, ou que a introducao dos "codons bacterianos" tenha contribuido para aumentar a expressao. Entretanto, e possivel que o aumento da expressao da proteina se deva a uma combinacáo destes varios fatores. Thompson \& cols. 
(1991) obtiveram maior rendimento na producao de bFGF usando a mesma abordagem, talvez porque tenham substituido cerca 120 bp do inflio da sequência codificadora. Os nossos niveis de expressao correspondem somente a proteina solúvel intracelular. Nao foi verificado se parte dos FGFs secretado para o meio (embora năo seja esperado pois nao tem peptideo sinal para issol e tambem nao se tentou recuperar FGF da fracao insolúvel (corpos de inclusao) uma vez que isto exige tratamentos drasticos, que levam a perda de atividade.

Ds FGFs foram purificados pelo procedimento que envolve basicamente: (1) obtença de um extrato bacteriano atraves de congelamento-descongelamento e passagem por "French-Press" e (2) eromatografia da fracăo solúvel em Heparina-Sepharose pela qual os FGFs tem afinidades diferentes: o hafGF e elufdo desta resina com cerca de $1,0 \mathrm{M}$ de $\mathrm{NaCl}$ enquanto o bbFGF requer cerca de 1,5 M do sal. Estas duas etapas sao suficientes para dar origem a proteinas com um grau de pureza da ordem de $95 \%$ ou mais, exibindo uma única banda visivel por coloracao com Coomassie-Blue apos eletroforese em gel de poliacrilamida-sDS (Figuras 20 e 23). A caracterizaça quimica posterior dos FGFs foi feita com proteinas neste estagio de purificacăo.

Foram determinadas as composicbes de aminoacidos $e$ as sequencias N-terminais das duas proteinas. Os resultados indicaram que as proteinas produzidas tem as sequencias primárias corretas. Os sequenciamentos mostraram ainda que praticamente $100 \%$ das metioninas iniciais de ambas as protefnas foram removidas e que no bbFGF cerca de $25 \%$ das moleculas perderam também o segundo residuo (alanina) durante o processamento na bacteria. Portanto, as proteinas resultantes devem corresponder aos fatores de crescimento autenticos (hafGF de 154 aminoacidos Jaye \& cols., 1986, e bbFGF de $153 / 154$ aminoacidos - Abraham \& cols., 1986a). Estes resultados indicam que os FGFs recombinantes obtidos sao adequados para futuros estudos do Iaboratorio.

As atividades biologicas dos dois fatores foram estudadas atraves de ensaios de estimulacão de sintese de DNA em 
fibroblastos das linhagens Swiss 3T3 e Balb/c 3T3. D haFgF recém-preparado mostrou-se ativo ao nivel de ng $\mathrm{ml}^{-1}$, e esta atividade desloca-se para a faixa de $p g m^{-1}$ quando heparina é adicionada ao meio de incubaça. O mecanismo de açăo da heparina nao esta totalmente esclarecido, mas é possivel que envolva mudanca da conformacao do FGF elou aumento da afinidade pelo receptor de membrana (Schreiber \& cols., 1985). Ja o bbFGF parece ser ativo na faixa de $\mathrm{pg} \mathrm{ml}^{-1}$ e a heparina nao exerce efeito significativo sobre este, embora dados de literatura mostrem a importancia da heparina quanto ao aumento de afinidade do fator ao receptor de alta afinidade (Yayon \& cols., 1991). Esta diferenca entre as atividades dos fGFs acido e basico em ensaios mitogenicos sobre fibroblastos e outros tipos celulares é também observada entre as proteinas extraidas de tecidos como cérebro e hipofise (Gospodarowicz, 1987). Os resultados descritos acima indicam, portanto, que as diferencas de atividades encontradas entre as proteinas recombinantes nao se devem a artefatos como, por exemplo dobramento incorreto. Por outro lado, preparacôes de FGFs recombinantes guardadas por muito tempo e submetidas a sucessivas etapas de congelamento e descongelamento sofrem um processo de inativacăo progressiva, devida aparentemente à formacăo de dimeros através de ligacoles dissulfeto entre cadeias diferentes (Robinson, 1991). Adicao de heparina a essas preparacbes reverte apenas parcialmente o processo (Schreiber \& cols., 1985). Um outro fator que deve ser levado em consideraço quanto à atividade dos fatores é que eles adsorvem nas paredes dos tubos de plasticos. Isto pode ser diminuido, utilizando-se: (1) PBS contendo BSA ( $1 \mathrm{mg} \mathrm{ml}^{-1}$ ) ou heparina (25 ug $\mathrm{ml}^{-1}$ ) ou DTT ( $10 \mathrm{mM}$ ) (Kan \& cols., 1991); (2) "3[(3-cholamidopropyl)dimethylammonio]-1-propane sulfonate" (CHAPS) (Matuo \& cols., 1991 ) como diluente dos fatores. Neste trabalno utilizamos PBS contendo ovoalbumina (250 ug $\mathrm{ml}^{-1}$ ) para os ensaios de atividade mitogenica. Esta metodologia havia sido utilizada anteriormente com os FGFs extraidos de tecidos (Ho \& cols., 1988). Embora algumas aliquotas de FGF tenham sido armazenadas na presenca de heparina, nao temos dados no momento que indiquem 
que o GAG efetivamente proteja as preparaçaes de fGF da perda de atividade por adsorcao. 


\section{REFERENCIAS BIBLIOGRAFICAS *}

ABRAHAM, J.A.; MERGIA, A.; WHANG, J.L.; TUMOLO, A.; FRIEDMAN, J.; HJERRILD, K.A.; GOSPODAROWICZ, D. \& FIDDES, J.C. (1986a). Nucleotide sequence of a bovine clone encoding the angiogenic protein, basic fibroblast growth factor. Science (Washington), 233: 545 - 548 .

ABRAHAM, J.A.; WHANG, J.L.; TUMOLD, A.; MERGIA, A. \& FIDdES, J.C. (1986c). Human basic fibroblast growth factor: nucleotide sequence, genomic organization, and expression in mammalian cells. Cold Spring Harbor Symp. Quant. Biol., 51: 657 - 668.

ABRAHAM, J.A.; WHANG, J.L.; TUMOLO, A.; MERGIA, A.; FRIEDMAN, J.; GOSPODAROWICZ, D. \& FIDDES, J. C. (1986b). Human basic fibroblast growth factor: nucleotide sequence and genomic organization. EMBO J., 5: 2523 - 2528 .

AMANN, E. \& BROSIUS, J. (1985). 'ATG vectors' for regulated highlevel expression of cloned genes in Escherichia coli. Gene, 40: 183 - 190.

ARMELIN, H.A. (1973). Pituitary extracts and steroid hormones in the control of $3 T 3$ cell growth. Proc. Natl. Acad. Sci. USA, 70: $2702-2706$.

BAIRD, A. \& KLAGSBRLN, M. (1991). The Fibroblast Growth Factor Family. Cancer Cel15, 3: $239-243$.

BAIRD, A.; MORMEDE, P.; YING, S.Y.; WEHRENBERG, W.B.; UEND, N.; LING, N. \& GUILLEMIN, R. (1985). A nonmitogenie pituitary function of fibroblast growth factor: regulation of thyrotropin and prolactin secretion. Proc. Natl. Acad. Sci. USA, 82: 5545 - 5549 .

BARR, P.J.; COUSENS, L.S.; LEE-NG, C.T.; MEDINA-SELBY, A.; MASIARZ, F.R.; HALLEWELL, R.A.; CHAMBERLAIN, S.H.; BRADLEY, J.D.; LEE, D.; STEIMER, K.S.; PCLLTER, L.; BURLINGAME, A.L.; ESCH, F. \& BAIRD, A. (1988). Expression and processing of biologically active fibroblast growth factors in the yeast Saccharomyces cerevisiae. J. Biol. Chem., 263: 16471 - 16478.

\footnotetext{
* Uma adaptacáo das normas para publicacao do Journal Biological Chemistry, 1991. As abreviaturas dos titulos dos periodicos seguem a CHEMICAL ABSTRACTS SERVICE SOURCE INDEX (CASSI), 1990.
} 
BLAM, S.B. MITCHELL, R.; TISCHER, E.; RUBIN, J.S.; SILVA, M.; SILVER, S.; FIDDES, J.C.; ABRAHAM, J.A. \& AARONSO, S.A. (1988). Adition of growth hormone secretion signal to basic fibroblast growth factor results in cell transformation and secretion of aberrant forms of the protein. Oncogene, 3: 129 136 .

BOLIVAR, F.; RODRIGUEZ, R.L.; GREENE, P.J.; BETLACH, M.C.; HEYNEKER, H.L. \& BOYER, H.W. (1977). Construction and characterization of new cloning vehicles. Gene, 2: 95 - 113.

BRADFORD, M. (1976). A rapid and sensitive method for the quantitation of microgram quantities of protein utilising the principle of protein-dye binding. Anal. Biochem., 72: 248 254.

BURGESS, W.H. \& MACIAG, T. (1989). The heparin-binding (fibroblast) growth factor family of proteins. Annu. Rev. Biochem., 58: 575 - 606.

BURGESS, W.H.; MEHLMAN, T.; MARSHAK, D.R.; FRASER, B.A. \& MACIAG, T. (1986). Structural evidence that endothelial cell growth factor $B$ is the precursor of both endothelial cell growth factor and acidic fibroblast growth factor. Proc. Natl. Acad. Sci. USA, 83: $7216-7220$.

CARTER, P. (1987). Improved oligonucleotide-direct mutagenesis using M13 vectors. Methods Enzymol., 154: 382 - 403.

COVARRUBIAS, L. \& BOLIVAR, F. (1982). Construction and characterization of new cloning vehicles. VI Plasmid pBR329, a new derivative of pBR328 lacking the 482-base-pair inverted duplication. Gene, 17: 79 - B9.

CRABB, J.W.; ARMES, L.G.: CARR, S.A.; JOHNSON, C.M.; ROBERTS, G.D.; BORDOLI, R.S. \& MCKEEHAN, W.L. (1986). Complete primary structure of prostatropin, a prostate epithelial cell growth factor. Biochemistry, 25: 4988 - 4993.

ESCH, F.; BAIRD, A.; LING, N.; UENO, N.; HILL, F.; DENOROY, L.; KLEPPER, R.; GOSPODAROWICZ, D.; BOHLEN, P.\& GUILLEMIN, R. (1985). Primary structure of bovine pituitary basic fibroblast growth factor (FGF) and comparison with the amino terminal sequence of bovine brain acidic FGF. Proc. Natl. Acad. Sci. USA, 82: $6507-6511$.

FLORKIEWICZ, R.Z. \& SOMMER, A. (1989). Humar basic fibrobIast growth factor gene encodes four polypeptides: three initiate 
translation from non-AUG codons. Proc. Natl. Acad. Sci. USA, 86: $3978-3981$.

FOX, G.M.; SCHIFFER, S.G.; ROHDE, M.F.; TSAI, L.B.; BANKS, A.R. \& ARAKAWA, T. (1988). Production, biological activity, and structure of recombinant basic fibroblast growth factor and an analog with cysteine replaced by serine. J. Biol. Chem., 263: 18452 - 18458 .

FUKUSHIMA, Y.; BYERS, M.G.; FIDDES, J.C. \& SHOWS, T.B. (1990). The human basic fibroblast growth factor gene (FGFB) is assigned to chromosome 4q25. Cytogenet. Cell Genet., 54: 159 160 .

GIMENEZ-GALLEGO, G.; RODKEY, J.; BENNETT, C.; RIOS-CANDELORE, M.; DISALVO, J. \& THOMAS, K. (1985). Brain-derived acidic fibroblast growth factor: complete amino acid sequence and homologies. Science (Washington), 230: 1385 - 1838.

GOSPODAROWICZ, D. (1975). Purification of a fibroblast growth factor from bovine pituitary. J. Biol. Chem., 250: 2515 2520 .

GOSPODAROWICZ, D. (1987). Isolation and characterization of acidic and basic fibroblast growth factor. In: Barnes, D. \& Sirbasku, D. A., ed., Methods Enzymol., 147B: 106 - 119.

GOSPODAROWICZ, D.; BAIRD, A.; CHENG, J.; LUI, G.M.; ESCH, F. \& BOHLEN, P. (1986). Isolation of fibroblast growth factor from bovine adrenal gland: Physicochemical and biological characterization. Endocrinology, 118: 82 - 90.

GOSPODAROWICZ, D.; CHENG, J.; LUI, G.M.; BAIRD, A.; ESCH, F. \& BOHLENN, P. (1985). Corpus luteum angiogenic factor is related to fibroblast growth factor. Endocrinology, 117: 2383 - 2391 .

GOSPODAROWICZ, D.; FERRARA, N.; SCHWEIGERER, L. \& NEUFELD, G. (1987a). Structural characterization and biological functions of fibroblast growth factor. Endocr. Rev., 8: 95 - 114.

GOSPODAROWICZ, D.; NEUFELD, G. \& SCHWEIGERER, L. (1987b). Fibroblast growth factor: structural and biological properties. J. Cell. Physiol., 5 (Suppl.): $15-26$.

HO, P.L.; CARPENTER, M.R.; SMILLIE, L.B. \& GAMBARINI, A.G. (1990). Co-purification of proteases with basic fibroblast growth factor (FGF). Biochem. Biophys. Res. Commun., 170: 769 -774 . 
HO, P.L.; JAKES, R.; NORTHROP, F.D. \& GAMBARINI, A.G. (1988). Pituitary fibroblast growth factor: immunocharacterization of an acidic component and $\mathrm{N}$-terminal sequence analysis of $a$ truncated basic component. Biochem. Int., 17: 973 - 980.

HOLMES, D.S. \& QUIGLEY, M. (1981). A rapid boiling method for the preparation of bacterial plasmids. Anal. Biochem., 114: 193 197.

HUNKAPILLER, M.W.; GRANLUND-MOYER, K. \& WHITELEY, N.W. (1986). Gas-phase proteins/peptides sequencer. In: Methods of protein microcharacterization: A practical handbook. (John E. Shively, ed.) p. 223 - 247, Humana Press, Clifton.

IMAMURA, T.; ENGLEKA, K.; ZHAN, X.; TOKITA, Y.; FOROUGH, R.; ROEDER, D.; JACKSON, A.; MAIER, J.A.M.; HLA, T.; MACIAG, T. (1990). Recovery of mitogenic activity of a growth factor mutant with a nuclear translocation sequence. Science (Washington), 249: 1567 - 1570 .

IWANE, M.; KUROKAWA, T.; SASADA, R.; SENO, M.; NAKAGAWA, S. \& IGARASHI, K. (1987). Expression of EDNA encoding human basic fibroblast growth factor in E. coli. Biochem. Biophys. Res. Commun., 146: $470-477$.

JAYE, M.; BURGESS, W.H.; SHAW, A.B. \& DROHAN W.N. (1987). Biological equivalence of natural bovine and recombinant human $\alpha$ - endothelial cell growth factors. J. Biol. Chem., 262: $16612-16617$.

JAYE, M.; HOWK, R.; BURGESS, W.; RICCA, G.A.; CHIU, I.M.; RAVERA, M.W.; O'BRIEN, S.J.; MODI, W.S.; MACIAG, T. \& DROHAN, W.N. (1986). Human endothelial cell growth factor: cloning, nucleotide sequence, and chromosome localization. Science (washington), 233: 541545.

JAYE, M.; LYALL, R.M.; MUDD, R.; SCHLESSINGER, J. \& SARVER, N. (1988). Expression of acidic fibroblast growth factor CDNA confers growth advantage and tumorigenesis to Swiss JT3 cells. EMBO J., 7: 963 - 969.

KAN, M.; SHI, Er-Gang \& MCKEEHAN, W.L. (1991). Identification and assay of fibroblast growth factor receptors. Methods Enzymol., 198: $158-171$.

KE, Y.; FERNIG, D.G.; SMITH, J.A.; WILKINSON, M.C.; ANANDAPPA, S.Y.; RUDLAND, P.S. \& BARRACLOUGH, R. (1990). High-level production of human acidic fibroblast growth factor in E. coli cells: inhibition of DNA synthesis in rat mammary fibroblasts 
at high concentrations of growth factor. Biochem. Biophys. Res. Commun., 171: $963-971$.

KLAGSBRUN, M.; SMITH, S.; SULLIVAN, R.; SHING, Y.; DAVIDSON, S.; SMITH, J.A. \& SASSE, J. (1987). Multiple forms of basic fibroblast growth factor: amino-terminal cleavages by tumor cell- and brain cell-derived acid proteinases. Proc. Natl. Acad. Sci. USA, 84: 1839 - 1843.

KNOERZER, W.; BINDER, H.P.; SCHNEIDER, K.; GRUSS, P.; MCCARTHY, J.E.G. \& RISAU, W. (1989). Expression of synthetic genes encoding bovine and human basic fibroblast growth factors (bFGFs) in Escherichia coli. Gene, 75: 21 - 30.

KUROKAWA, T.; SASADA, R.; IWANE, M. \& IGARASHI, K. (1987). Cloning and expression of CDNA encoding human basic fibroblast growth factor. FEBS Lett., 213: 189 - 194.

LAEMMLI, U.K. (1970). Cleavage of structural proteins during the assembly of the head of bacteriophage T4. Nature (London), 227: 680 - 685 .

LIM, H.M. \& PENE, J.J. (1988). Optimal conditions for supercoil DNA sequencing with the Escherichia coli DNA polimerase I large fragment. Gene Anal. Tech., 5: 32 - 39. Apud: Chem. Abstr., 109: 1830b, 1988.

LiNEMEYER, D.L.; KELLY, L.J.; MENKE, J.G.; GIMENEZ-GALLEGO, G.; DI SALVO, J. \& THOMAS, K.A. (1987). Expression in Escherichia coli of a chemically synthesized gene for biologically active bovine acidic fibroblast growth factor. Biotechnology, 5: 960 - 965.

MANDEL, M. \& HIGA, A. (1970). Calcium-dependent bacteriophage DNA infection. J. Mol. Biol., 53: 159 - 162.

MANIATIS, T.; FRITSCH, E.F.; SAMBROOK, J. (1982). - Molecular Cloning: a laboratory manual. Cold Spring Harbor Laboratory, New York, $545 \mathrm{p}$.

MATUO, Y.; NISHI, N.; MATSUMOTO, K.; MIYAZAKI, K.; MATSUMOTO, K.; SUZUKI, F. \& NISHIKAWA, K. (1991). 3-[(3-Cholamidopropyl) dimethylammonio]-1-propane sulfonate as noncytotoxic stabilizing agent for growth factors. Methods Enzymol.. 198: $511-518$.

MCKEEHAN, W.L. \& CRABB, J.M. (1987). Isolation and characterizatiori of different molecular and chromatographic 
forms of heparin-binding growth factor 1 from bovine brain. Anal. Biochem., 164: 563 - 569.

MERGIA, A.; EDDY, R.; ABRAHAM, J.A.; FIDDES, J.C. \&HOWS, T.B. (1986). The genes for basic and acidic fibroblast growth factors are on different human chromosomes. Biochem. Biophys. Res. Commun., 13日: 644 - 651 .

MOSCATELLI, D.; PRESTA, M. \& RIFKIN, D. (1986). Purification of a factor from human placenta that stimulates capillary endothelial cell protease production, DNA synthesis, and migration. Proc. Natl. Acad. Sci. USA, 83: 2091 - 2095.

NEUFELD, G.; MITCHELL, R.; PONTE, P. \& GOSPODAROWICZ, D. (1988). Expression of human basic fibroblast growth factor CDNA in baby hamster kidney-derived cells results in autonomous cell grwoth. J. Cell Biol., 106: 1385 - 1394.

OKUMURA, T.; UEHARA, A.; TSUJI, K.; TANIGUCHI, Y.; KITAMORI, 5.; SHIBATA, Y.; OKAMURA, K.; TAKASUGI, Y. \& NAMIKI, M. (1991). Central nervous system action of basic fibroblast growth factor: inhibition of gastric acid and pepsin secretion. Biochem. Biophys. Res. Commun., 175: $527-531$.

PLATA-SALAMAN, C.R. (1989). Food intake suppession by growth factors and platelet peptides by direct action in the central nervous system. Nourosel. Lett., 94: 161 - 166.

PRATS, H.; KAGHAD, M.; PRATZ, A.C.; KLAGSERUN, M.; LELIAS, J.M.; LIAUZUN, P.; CHALON, P.; TAUBER. J.P.; AMALRIC, F.; SMITH, J.A. \& CAPUT, D. (1989). High molecular mass forms of basic fibroblast growth factor are initiated by alternative CUG codons. Proc. Nat1. Acad. Sci. USA, 86: 1836 - 1840.

PRESTA, M.; MOSCATELLI, D.; JOSEPH-SILVERSTEIN, J. \& RIFKIN, D.B. (1986). Purification from a human hepatoma cell line of a basic fibroblast growth factor-like molecule that stimulates capillary endothelial cell plasminogen activator production, DNA synthesis, and migration. Mol. Cell. Biol., 6: 4060 4066 .

ROBINSON, C.J. (1991). Tailoring and targeting fibroblast growth factors. Trends Biotechnol., 9: 147 - 148 .

ROGELJ, S.; WEINBERG, R.A.; FANNING, P. \& KLAGSBRUN, M. (1988). Basic fibroblast growth factor fused to a signal peptide transforms cells. Nature (London), 331: 173 - 175. 
SAMBROOK, J.; FRITSCH, E.F. \& MANIATIS T. (1989). - Molecular Cloning: a laboratory manual. 2. ed. Cold Spring Harbor Laboratory, Press, New York.

SANGER, F.; NICKLEN, S. \& COULSON, A.R. (1977). DNA sequencing with chain-terminating inhibitors. Proc. Natl. Acad. Sci. USA, 74 : $5463-5467$.

SASADA, R.; KUROKAWA, T.; IWANE, M. \& IGARASHI, K. (198B). Transformation of mouse Balb/c $3 T 3$ cells with human basic fibroblast growth factor CDNA. Mol. Cell. Biol., 8: 588 - 594.

SCHREIBER, A.B.; KENNEY, J.; KOWALSKI, W.J.; FRIESEL, R.; MEHLMAN, T. \& MACIAG, T. (1985). Interaction of endothelial cell growth factor with heparin: characterization by receptor and antibody recognition. Proc. Natl. Acad. Sci. USA, 82: 6138 -6142 .

SENO, M.; SASADA, R.; KUROKAWA, T. \& IGARASHI, K. (1990). Carboxil-terminal structure of basic fibroblast growth factor significantly contributes to its affinity for heparin. Eur. J. Biochem., 188: 239 - 245 .

SPACKMAN, D.H.; STEIN, W.H. \& MOORE, S. (1958). Automatic recording apparatus for use in the chromatography of amino acids. Anal. Chem., 30: 1190 - 1206.

SPORN, M.B. \& ROBERTS, A.B. (1988). Peptide growth factors are multifuncional. Nature (London), 332: 217 - 219.

SQUIRES, C.H.; CHILDS, J.; EISENBERG, S.P.; POLVERINI, P.J. \& SOMMER, A. (1988). Production and characterization of human basic fibroblast growth factor from Escherichia coli. J. Biol. Chem., 263: 16297 - 16302 .

STUDIER, F.W.: ROSENEERG, A.H.; DUNN, J.J. \& DUBENDORFF, J.W. (1990). Use of T7 RNA Dolymerase to direct expression of cloned genes. Methods Enzymol., 185: 60 - 89.

THOMAS, K.A.; RILEY, M.C.; LEMMON, S.K.; BAGLAN, N.C. \& BRADSHAW, R.A. (1980). Brain fibroblast growth factor: Non-identity with myelin basic protein fragments. J. Biol. Chem., 255: 5517 5520 .

THOMAS, K.A.; RIOS-CANDELORE, M. \& FITZPATRICK, S. (1984). Purification and characterization of acidic fibroblast growth factor from bovine brain. Proc. Natl. Acad. Sci. USA, 81: 357 $-361$. 
THOMPSON, S.A.; PROTTER, A.A.; BITTING, L.; FIDDES, J.C. \& ABRAHAM, J.A. (1991). Cloning, Recombinant Expression, and Characterization of Basic Fibroblast Growth Factor. Methods Enzymol., 198: 96 - 116.

TOGARI, A.; BACKER, D.; DICKENS, G. \& GURDFF, G. (1983). The neurite promoting effect of fibroblast growth factor on PC12 cells. Biochem. Biophys. Res. Commun., 114: 1189 - 1193.

UENO, N.; BAIRD, A.; ESCH, F.; LING, N. \& GUILLEMIN, R. (19B6). Isolation of an amino terminal extended form of basic fibroblast growth factor. Biochem. Biophys. Res. Commun., 138: $580-588$.

WATANABE, T.; SENO, M.; SASADA, R. \& IGARASHI, K. (1990). Molecular characterization of recombinant human acidic fibroblast growth factor produced in E. coli: comparative studies with human basic fibroblast growth factor. Mol. Endocrinol., 4: 869 - 879.

YANISCH-PERRON, C.; VIEIRA, J. \& MESSING, J. (1985). Improved M13 phage cloning vectors and host strains: nucleotide sequences of the M13mp18 and pUC19 vectors. Gene, 33: 103 - 119.

YAYON, A.; KLAGSBRUN, M.; ESKO, J.D.; LEDER, P. \& ORNITZ, D.M. (1991). Cell surface, heparin-like molecules are required for binding of basic fibroblast growth factor to its high affinity receptor. Cel1, 64: 841 - 848. 